\title{
As paixões humanas em Thomas Hobbes
}

entre a ciência e a moral, o medo e a esperança

\section{Hélio Alexandre da Silva}

SILVA, HA. As paixões humanas em Thomas Hobbes: entre a ciência e a moral, o medo e a esperança [online]. São Paulo: Editora UNESP; São Paulo: Cultura Acadêmica, 2009. 121 p. ISBN 978-857983-024-2. Available from SciELO Books <http://books.scielo.org>.

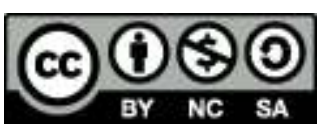

All the contents of this chapter, except where otherwise noted, is licensed under a Creative Commons Attribution-Non Commercial-ShareAlike 3.0 Unported.

Todo o conteúdo deste capítulo, exceto quando houver ressalva, é publicado sob a licença Creative Commons Atribuição Uso Não Comercial - Partilha nos Mesmos Termos 3.0 Não adaptada.

Todo el contenido de este capítulo, excepto donde se indique lo contrario, está bajo licencia de la licencia Creative Commons Reconocimento-NoComercial-CompartirIgual 3.0 Unported. 


\section{AS PAIXÕES HUMANAS EM THOMAS HOBBES}

ENTRE A CIÊNCIA E A MORAL, O MEDO E A ESPERANÇA

HÉLIO ALEXANDRE DA SILVA 
As PaIXÕes HUMANAS EM ThOMAS HobBes 



\section{HÉLIO ALEXANDRE DA SILVA}

\section{As PaIXôes humanas EM ThOMAS HobBes}

ENTRE A CIÊNCIA E A MORAL, O MEDO E A ESPERANÇA 
(C) 2009 Editora UNESP

\section{Cultura Acadêmica}

Praça da Sé, 108

01001-900 - São Paulo - SP

Tel.: (0xx11) 3242-7171

Fax: (0xx11) 3242-7172

www.editoraunesp.com.br

feu@editora.unesp.br

CIP - Brasil. Catalogação na fonte

Sindicato Nacional dos Editores de Livros, RJ

S58p

Silva, Hélio Alexandre da

As paixões humanas em Thomas Hobbes : entre a ciência e a moral, o medo e a esperança / Hélio Alexandre da Silva. - São Paulo : Cultura Acadêmica, 2009.

Inclui bibliografia

ISBN 978-85-7983-024-2

1. Hobbes, Thomas, 1588-1679. 2. Ciência política - Filosofia.

3. Direito natural. 4. Ética. 5. Esperança. 6. Medo. I. Título.

09-6220.

CDD: 320.15

CDU: 321.011

Este livro é publicado pelo Programa de Publicações Digitais da Pró-Reitoria de Pós-Graduação da Universidade Estadual Paulista "Júlio de Mesquita Filho" (UNESP)

Editora afiliada:

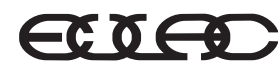

Asociación de Editoriales Universitarias de América Latina y el Caribe

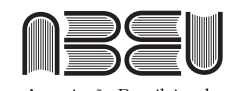

Associação Brasileira de Editoras Universitárias 
Dedico esse trabalho à memória de Hélio José da Silva, em louvor e reconhecimento a sua prudência e responsabilidade no desempenho da árdua tarefa de pai. 



\section{Agradecimentos}

Quero agradecer ao apoio, estímulo e reconhecimento de toda minha família, principalmente minha mãe Dona Dirce, de força e dedicação incomparáveis e ao meu irmão Bruno, companheiro de pescaria com quem compartilho a óciofilia. Agradeço também, e de maneira especial, a Maria Érbia pela companhia de valor inestimável, pela cumplicidade sempre presente em todos os momentos desde os anos de graduação. Ao "Círculo de Marília", Rafael, Henrique, Thiago e ao distante Marcelo pela amizade cultivada, pelas intensas e extremamente frutíferas discussões lógicas, metafísicas, hedonistas e políticas (não necessariamente nessa ordem) que ocorrem sempre que o "Círculo" se reúne. À Renata, pela amizade redescoberta. Ao Herbert e Eloisa pelas conversas sempre muito agradáveis sobre política, universidade e filosofia. Aos moradores da casa 12 da moradia estudantil da Unesp/Marília que muito me ajudaram com a companhia e as divertidas conversas principalmente durante os anos de 2005 e 2006. À professora Maria Isabel Limongi pelas valiosíssimas contribuições na banca de qualificação. A professora Yara Frateschi pela participação na banca de qualificação e na desfesa desse trabalho, bem como por sua atenção e prontidão em apontar os melhores atalhos para uma boa compreensão da filosofia de Hobbes. 
Agradeço à Capes e ao programa de bolsa mestrado do governo do estado de São Paulo para professores da rede estadual de ensino pelas bolsas concedidas. Agradeço também ao professor Ricardo Monteagudo pela orientação e pelo acompanhamento de meus estudos desde a graduação. 


\section{SUMÁRIO}

Prefácio 11

Apresentação 13

1 Ciência e Filosofia 19

2 Uma abordagem crítica: Taylor, Strauss e Warrender 47

3 As paixões humanas 77

Considerações finais 111

Referências bibliográficas 119 



\section{Prefácio}

Thomas Hobbes é autor obrigatório para todos aqueles que se interessam por filosofia política (na verdade, para todos aqueles que se interessam por política, pela ótica de qualquer campo teórico). Mas é um autor diminuído, simplificado, barateado, ao qual atribuímos a paternidade do estado enquanto leviatã e mais meia dúzia de frases célebres: "o homemé o lobo do homem", "os pactos sem espada não passam de palavras" etc. É que normalmente restringimos a vasta, viva e tensa obra de Hobbes a meia dúzia de capítulos do Leviatã, a começar do décimo terceiro capítulo dessa obra. Como se a primeira tese fosse aquela da guerra generalizada de todos contra todos e a última fosse a defesa do Estado absoluto. É uma estratégia do leitor preguiçoso, que combina com manuais e rótulos e não combina nada com uma atitude filosófica genuína e séria. Para começar a desfazer os preconceitos, é preciso lembrar que Hobbes não é autor de uma única obra e que o Leviatã não começa no capítulo XIII. Mais ainda: Hobbes queria ter feito um sistema filosófico e todo o seu longo percurso intelectual afirmou e reafirmou o propósito de fazer que os diversos campos da filosofia dialogassem de forma sistemática. Isso significa que, para compreender a grande tese da política hobbesiana, é preciso dar alguns passos atrás daquele que costumamos adotar como o primeiro e procurar as bases dessa filosofia política. É precisamente isso o que procura fazer Hélio Alexandre da Silva em seu primeiro (e espero que não o último!) trabalho de fôlego sobre Thomas Hobbes. 
O grande mérito da dissertação de mestrado de Hélio Alexandre da Silva é não se contentar com aquele velho e bom (bom ou vilão, tanto faz) Hobbes conhecido de todos nós: o autor está à procura dos fundamentos da filosofia política hobbesiana e, nessa busca, chama para o centro de seu trabalho a relação entre a filosofia natural e a filosofia civil. Com isso o autor revela sua rebeldia e insubordinação em relação a toda uma literatura que, em épocas distintas e com propósitos diversos, recusou terminantemente a importância dessa relação para a fundamentação das teses centrais da política hobessiana. Ao contrário dessa atitude crítica padrão, Hélio Alexandre da Silva procura entender o que é e como se estabelece esse sistema tornandose capaz de ver que a política não se sustenta - filosoficamente - nela mesma, mas recua para a moral, que recua para a física. Isso permite ao autor fazer uma crítica muito bem fundamentada (excelente!) da famosa e equivocada tese Taylor-Warrender. Toda a dissertação converge para elucidar, no terceiro capítulo, a importância das paixões, principalmente o medo e a esperança, na construção da paz na perspectiva do mecanicismo e, portanto, da relação entre a filosofia natural e civil. Mas essa abordagem não confina o autor em uma perspectiva "naturalista", porque ao mesmo tempo em que ele recupera a física com toda a sua importância, nem por isso deixa de ressaltar a relevância do contexto de formação das paixões. Se há uma natureza operando com toda a sua força no homem e o conduzindo à guerra, há também a possibilidade de contornar os efeitos potencialmente devastadores da paixão modificando o contexto de sua formação.

Não pretendo aqui antecipar o resultado admirável desse trabalho, mas dizer que ele é admirável porque não simplifica, não reduz e não barateia Hobbes. O autor não começa no capítulo XIII do Leviatã, mas nos dá, isso sim, bons subsídios para compreendê-lo. Além do mais, As paixões humanas em Thomas Hobbes: entre a ciência e a moral, o medo e a esperança é um enfretamento das dificuldades e tensões da obra de Hobbes que assume uma atitude filosófica séria e genuína. 


\section{ApresentaÇÃo}

No prefácio de Do Cidadão, Hobbes diz que as afecções da mente (paixões humanas) não podem ser tomadas como perversas em si mesmas e o exemplo disso pode ser apresentado quando observamos uma criança que tem fome e não é alimentada, ela chora e pode se tornar agressiva, porém isso não significa que ela seja má, mas sim que ela reage a uma necessidade natural.

As afeições da mente que surgem somente das partes inferiores da alma não são perversas em si mesmas [...]. Se não dermos às crianças tudo o que elas pedem, elas serão impertinentes, e chorarão, e às vezes até baterão em seus pais, e tudo isso farão por natureza; e no entanto não têm culpa, e não será apropriado dizê-las más (Hobbes, 1998, p.17-8).

O mesmo pode ser observado no Leviatã quando Hobbes diz que "Os desejos e outras paixões do homem não são em si mesmos um pecado. Tampouco o são as ações que derivam dessas paixões" (Hobbes, 2003, p.110). O propósito desse trabalho é compreender as possibilidades e as implicações dessa afirmação, ou seja, entender as paixões humanas na obra de Hobbes como um movimento de 
reação ${ }^{1}$ à ação do movimento de objetos externos de modo que, por isso, elas não podem ser tomadas como boas ou más em si mesmas, mas sim como reações naturais próprias da lógica de funcionamento de todos os corpos naturais, inclusive o homem. Nesse sentido, a ética (que para Hobbes é o estudo das consequências das paixões da mente) deve ser melhor compreendida se a tomarmos como parte derivada da análise dos corpos naturais, e que, portanto, remete à consideração acerca da ciência física, como é exposto na tábua do conhecimento ilustrada por Hobbes no cap. IX do Leviatã.

Brevemente, é possível descrever esse capítulo da obra hobbesiana da seguinte forma:

Da Filosofia (ou conhecimento das causas e consequências) deriva a filosofia natural e a filosofia política ou civil. Da filosofia natural surge a física (consequência das qualidades dos corpos). Esses corpos podem ser transitórios ou permanentes. Do estudo das consequências dos corpos permanentes deriva o estudo das consequências dos corpos terrestres, do estudo dos corpos terrestres surge o estudo das consequências das partes da terra (que não têm sensação) e o estudo das consequências das qualidades animais. A partir da consideração das qualidades animais, têm-se dois objetos de estudo: a consequência das qualidades dos animais em geral e a consequência das qualidades do homem em especial. E, por último, do estudo das consequências da consideração do homem deriva o estudo das consequências das paixões da mente, que é o que Hobbes nomeia Ética.

No entanto, entender que as paixões humanas devem ser pensadas a partir da consideração da ciência dos corpos naturais não significa que não exista em Hobbes uma antropologia, isto é, características que permitam distinguir e definir o que é próprio do homem enquanto corpo natural daquilo que é comum a todos os demais

1 Entender as paixões como reação não significa que elas sejam simples reações mecânicas que se seguem diretamente da ação de objetos externos, é preciso notar que o homem hobbesiano pode deliberar acerca de suas vontades e que a imaginação possui conteúdos experienciais que auxiliam na formação das paixões. Tais considerações porém serão feitas no terceiro capítulo desse trabalho que tratará especificamente das paixões humanas. 
corpos naturais. Contudo, mesmo essa consideração de caráter antropológico também pode ser feita à luz da ciência mecanicista, ou seja, considerando a existência de uma relação entre a filosofia natural e a filosofia política na obra de Hobbes.

O primeiro momento desse trabalho será desenvolvido com o intuito de tentar expor essa hipótese, assim o ponto de partida, ou seja, o primeiro capítulo, será a análise da ciência hobbesiana, a saber, do De Corpore, não com a intenção de compreender toda a obra, mas com o intuito de apontar os conceitos que Hobbes utiliza em sua abordagem da filosofia moral e da política. Desse modo, o intuito é buscar na filosofia natural não apenas o vocabulário, mas algo como um "padrão comum de interpretação" presente em toda a obra hobbesiana, isto é, buscar na própria obra do filósofo inglês aspectos que nos permitam sustentar uma relação direta ou indireta entre a ciência mecanicista e a política, de tal modo que as paixões humanas possam ser consideradas a partir dessa relação.

Como consequência dessa leitura que busca entender a obra de Hobbes como um todo coerente entre suas partes constitutivas, isto é, filosofia natural, filosofia moral e política, é que se seguirá o segundo capítulo desse trabalho. Nesse momento, será preciso dialogar com alguns intérpretes que não compactuam com a visão que entende a obra hobbesiana como um todo que deva ser compreendido a partir de uma interpretação que se inicie pela filosofia natural, ou seja, pela consideração da ciência dos corpos naturais.

Trabalharemos brevemente três desses autores que reconhecidamente se situam entre aqueles que sustentam uma interpretação que vê em Hobbes um princípio que pode não ser necessariamente científico. Contudo, a abordagem a esses autores irá se restringir apenas ao ponto que se faz relevante para esse trabalho, de modo que não serão exaustivamente reconstruídos todos os argumentos que eles desenvolvem no sentido de sustentarem suas interpretações da obra hobbesiana. O ponto que cabe aqui analisar é o motivo que faz com que Warrender e Taylor (cada um a seu modo, como veremos no capítulo 2) possam sustentar a existência de uma moral a priori sem que seja necessária a consideração da ciência natural de matriz 
mecanicista. E também analisaremos o argumento que faz com que Strauss possa sustentar a independência da moral e da política com relação à ciência moderna, já que a moral e a política estariam fundadas na experiência de cada um e não na ciência natural. Desse modo, analisaremos brevemente a posição de cada um desses autores:

- Warrender, que substitui a ciência pela lei divina;

- Taylor, que no lugar da ciência lança mão de um princípio a priori semelhante ao imperativo categórico kantiano;

- Strauss, que elege a experiência de uma paixão, a vaidade, como princípio norteador da moral hobbesiana.

Assim, cada qual a seu modo, defende a ideia de que a filosofia natural pode ser desconsiderada quando o intuito for compreender a filosofia moral e a política hobbesiana. Esses autores só podem levar a cabo suas respectivas interpretações graças ao fato de não considerarem a relação que o trabalho que aqui se apresenta supõe existir. Para realizar a crítica em relação à visão dos autores supracitados, apoiar-nos-emos em vários comentadores da obra de Hobbes, porém a ênfase será dada especialmente na abordagem realizada por Thomas Spragens na obra Politics of Motion.

Posteriormente, será dado o terceiro e último passo, qual seja, a consideração das paixões humanas como reação à ação de movimentos de objetos externos. Ora, como considerar as paixões humanas como um movimento de ação e reação provocada pela incidência de objetos externos, se Hobbes afirma que existe um movimento ínfimo que é o "início dos movimentos, no interior do corpo do homem, antes de se manifestarem no andar, na fala, na luta e em outras ações visíveis, [que] chama-se geralmente ESFORÇO" (Hobbes, 2003, p.47). ${ }^{2}$ Bem, é possível entender esse esforço (conatus) como um movimento. Porém, não é apenas um simples movimento mas um movimento primordial, inicial e interno que possui sua origem na

2 Principia haec motus parva, intra humanum corpus sita, antequam incedendo, loquendo, percutiendo, caeterisque actionibus appareant, vocantur conatus(Opera Latina, in Hobbes, 1966b, v.2, p.40, grifo do autor). 
ação dos movimentos dos objetos externos que afetam os sentidos e são levados até o interior do corpo humano. Atingido o interior do corpo humano esse movimento se manifestará como um movimento primordial e interno, isto é, como um esforço (conatus) que é o início dos demais movimentos humanos.

No terceiro capítulo, abordaremos a questão das paixões humanas, entretanto não será analisado todo o aparato passional hobbesiano, mas apenas duas paixões em especial, qual seja, a esperança (que é expectativa de bem futuro) e o medo (expectativa de mal futuro). O motivo de escolher essas duas paixões é a relevância que Hobbes oferece a elas como duas paixões que, ao lado da razão, levam o homem a sair do estado de natureza (caracterizado pela guerra e pela desconfiança) e construir o pacto que possibilita a edificação do aparato jurídico necessário para sustentar o Estado civil (caracterizado pela paz e pela confiança). Ao dar relevância a essas duas paixões em especial, parece ser possível entendê-las como um tipo de medida moral universalmente válida que é capaz de construir um acordo natural entre os homens no sentido da necessidade da construção do Estado soberano. No entanto, é em outro sentido que pretendemos entender tal relevância dada à esperança e ao medo, qual seja, como paixões humanas que não são capazes de oferecer tal universalidade moral, pois são reações causadas pela ação do movimento de objetos externos, e nesse sentido não é possível um acordo (pacto) comum entre os homens no estado de simples natureza que possa ser confiável, pois sem o Estado civil o que vigora é a desconfiança mútua gerada pela competição natural pelos meios que auxiliam a preservação da vida. E onde há desconfiança não há espaço para contratos.

Amparado no que foi discutido nos dois primeiros capítulos, faremos a discussão do terceiro, de modo que sem a consideração prévia da filosofia natural não seria possível dar cabo da análise das paixões humanas no sentido que aqui se pretende, ou seja, como reações provocadas pela ação do movimento de corpos externos e que, por isso, não são capazes de oferecer uma universalidade capaz de unir os homens no simples estado de natureza. 



\section{CIÊNCIA E FILOSOFIA $^{1}$}

\section{A filosofia natural: chave explicativa da ética e da política}

A filosofia natural ${ }^{2}$ é o conhecimento da verdadeira regra da vida, e a guerra está amparada fundamentalmente na ignorância dessas regras conforme anuncia Hobbes no De Corpore. É nessa obra de 1655 que Hobbes expõe de forma mais acurada e minuciosa sua teoria física, ainda que no Leviatã (1651) e nos Elementos de Lei (1640)3 já

1 Nesse trabalho, tomaremos por ciência (filosofia natural) o equivalente ao conceito de física, pois ainda que na obra de Hobbes ciência não se refira exclusivamente à consequência dos acidentes (aparências) dos corpos naturais (que é o que Hobbes entende por física), para nosso propósito não será necessário abordar detidamente outras ciências como a matemática e a geometria (que é a consequência da quantidade e movimento determinados pela figura e pelo número) (Hobbes, 1966b, p.74). Portanto, toda menção à ciência que constar nesse trabalho fará referência à ciência física.

2 "Therefore, the cause of civil war is that people are ignorant of the cause of wars and peace and that there are very few who have leanerd their responsibilities, by which peaces flourishes and is preserved, that is, the true rule of living. But moral philosophy is knowledge of this rule" (Hobbes, 1966d, p.185, grifo nosso).

3 Os Elements Of Law foi publicado primeiramente em $1650 \mathrm{em}$ duas partes distintas (Human Nature e De Corpore Político) e, posteriormente, em 1889, essas duas partes foram publicadas conjuntamente sob o título de Elementos de 
existam formulações que tratam dos movimentos dos corpos, de seu funcionamento e de suas semelhanças no que se refere à aplicação no homem da mecânica fisicalista que não é apenas uma característica própria da natureza das coisas, mas que também se aplica à natureza humana. A compreensão desse processo pode ser alcançada por meio da clarificação e do entendimento de dois conceitos fundamentais que norteiam a construção hobbesiana de ciência e de física, quais sejam, o conceito de corpo e de movimento. Porém, antes de analisar esses dois conceitos, pretende-se aqui mostrar que, apenas ao entender a realidade do universo como uma espécie de cosmologia constituída de corpos em movimento é que Hobbes passa da explicação da filosofia da natureza à explicação da natureza humana, sem que seja necessário mudar a chave conceitual básica dessa explicação que é mecânica. Antes ainda, é necessário notar a possibilidade de aproximação entre as definições de filosofia e ciência na obra de Hobbes. Perceber tal semelhança permitirá pensar essa chave explicativa comum entre a filosofia natural e a filosofia moral e política.

Nesse sentido, não é apressado dizer que tanto a filosofia como a ciência são estudos das aparências das coisas que atingimos por meio da sensação, e que o cálculo racional dessas aparências é o que chamamos de conhecimento. Assim, sustentar a concepção de filosofia como "o conhecimento dos efeitos ou aparências, tal como adquirimos pelo raciocínio verdadeiro" (Hobbes, 1966d, p.3) e ao mesmo tempo dizer que a ciência é a "evidência da verdade, a partir de algum início ou princípio da sensação” (Hobbes, 1969, p. $25-6)^{5}$ permite a Hobbes, no Leviatã, unir ciência e filosofia em uma mesma definição, já que "ciência, isto é, [o] conhecimento das consequências; é também chamada de filosofia” (Hobbes, 2003,

Lei Natural e Política. Essa união dos dois textos, inicialmente publicados separadamente pelas mãos de Hobbes, permanece até os dias de hoje como abertamente aceita entre os estudiosos da obra hobbesiana. Cf. Hobbes, 1969b. p.v ss.

4 "Philosophy is such knowledge of effects or appearances, as we acquire by true ratiocination..." (Hobbes, 1966d, p.3).

5 "I define to be evidence of truth, from some beginning or principle of sense." (Hobbes, 1969a, p.25-6). 
p.74). O conhecimento dos efeitos e das aparências apontado no $D e$ Corpore percorre o mesmo caminho metodológico que a afirmação contida nos Elements of Law que diz que a ciência é evidência da verdade. Tanto em uma quanto na outra a preocupação de Hobbes é mostrar que a ciência e a filosofia só podem ser construídas se bem amparadas em bases verdadeiras. E verdade para Hobbes deve ser tomada como um conceito que exprime uma proposição verdadeira enunciada pelo correto raciocínio ou cálculo de nomes, "pois verdade e uma proposição verdadeira são uma só coisa” (Hobbes, 1969, p.21).

O que está presente nessa aproximação entre filosofia e ciência é a necessidade do uso da razão ${ }^{6}$ enquanto cálculo, pois muito embora as sensações, a memória, a prudência (que é expectativa obtida por uma experiência) e a experiência (que é memória) possam ser consideradas conhecimento, que inclusive partilhamos com os animais, ainda assim não podemos chamá-las de ciência nem de filosofia, pois o saber por elas produzido não deriva do cálculo de nomes ou de fatos, isto é, não deriva da razão. A experiência simples acumulada através dos tempos, e a memória (fantasma) produzida por essa experiência, não podem ser tidas como saber científico nem mesmo filosófico, pois não necessitam do cálculo racional para serem alcançadas. Por isso a razão, isto é, o cálculo, é condição sine qua non para que um determinado conhecimento possa ser caracterizado como pertencente ao domínio filosófico ou científico.

A finalidade da razão, contudo, é calcular as significações fixas dos nomes de tal modo a construir uma cadeia onde a última conclusão se siga da certeza das afirmações e negações das premissas (Hobbes, 1998, p.40-1). Nesse sentido, o cálculo de nomes atribuídos às aparências das coisas é o que permite compreender as imagens e os

6 Hobbes é claro ao referir-se ao que entende por razão, ela "nada maisé que cálculo (isto é, adição e subtração) das consequências de nomes gerais estabelecidos para marcar e significar os nossos pensamentos" (Hobbes, 1998, p.40, grifo do autor). E ainda: "Por reta razão no estado de natureza humana, não entendo (como querem muitos) uma faculdade infalível, porém o ato de raciocinar - isto é, o raciocínio peculiar e verdadeiro de cada homem acerca daquelas suas ações que possam resultar em detrimento ou benefício de seus próximos" (idem, p.361). 
fantasmas provenientes da sensação e presentes na memória. Quando o homem realiza o cálculo (raciocínio) dessas aparências de modo a adquirir conhecimento de suas causas ou de seus efeitos, pode se chamar esse conhecimento que foi alcançado de Filosofia (Hobbes, 1966d, p.12). Da mesma forma, porém em outras palavras, Hobbes mostra que a definição de ciência não se distancia da definição forjada para explicar o que se entende por filosofia, já que chamamos de ciência o conhecimento que é alcançado, em primeiro lugar, através de uma adequada imposição de nomes.

e em segundo lugar [é] obtendo-se um método bom e ordenado para proceder aos elementos, que são nomes, a asserções feitas por conexão de um deles com o outro, e daí para os silogismos, que são as conexões de uma asserção com outra, até chegarmos a um conhecimento de todas as consequências de nomes pertencentes a um assunto em questão, é a isto que os homens chamam de CIÊNCIA (Hobbes, 2003, p.43-4, grifo nosso).

A razão como cálculo de nomes é ferramenta que, em grande medida, sustenta o edifício teórico hobbesiano. No decorrer do trabalho será abordada com mais acuidade a questão do método (analítico e sintético), e quanto à linguagem entende-se que não cabe, para efeito de elaboração deste trabalho, fazer uma análise detida e pormenorizada, ${ }^{7}$ ainda que ela seja de grande relevância

7 Para Hobbes, a linguagem é a mais nobre invenção produzida pelo artifício humano, e é dessa característica artificial ou convencional que ele retira toda força que ela possui. A linguagem exerce sua função ao distanciar-se da realidade de conflito presente no estado de simples natureza e atribuir nomes a coisas, fatos, paixões etc. de modo que esses nomes nada mais são que marcas ou signos que permitem pensar os corpos sob a aparência de rigidez e fixidez necessária para estabelecer regras e leis no âmbito do convívio comum. A esse respeito, Maria Isabel Limongi afirma: "O discurso verbal é aquele que se afasta dos fatos e se constrói acima deles. É daí que ele retira sua força (...) Mas é daí também que se segue sua fraqueza." (Limongi, 1994, p.152). No entanto, por detrás desses nomes "rótulos" que cristalizam os fatos, objetos, paixões etc a natureza permanece sempre a mesma, isto é, a tensão natural característica do estado de 
na construção da filosofia hobbesiana. Porém, o que importa aqui é entender que o que caracteriza um conhecimento como filosófico ou científico é sua origem racional e calculadora adquirida por meio de demonstrações das consequências de uma afirmação para outra.

Assim, pode se dizer que a razão ou recta ratio $^{8} \mathrm{em}$ Hobbes possui uma função instrumental e calculadora. Instrumental na medida em que é utilizada pelo homem como um meio (instrumento) útil para proceder aos cálculos de nomes, e calculadora na medida em que sua principal função é calcular os nomes dos objetos e fatos, de modo a construir um discurso coerente capaz de propiciar ao homem a saída do estado de simples natureza, que é de guerra de todos contra todos, por meio do pacto que institui um poder soberano capaz de promover a paz, a segurança e a estabilidade que inexiste no estado de natureza. Porém, algumas passagens do texto hobbessiano propiciam uma leitura em favor de uma visão que privilegie uma concepção de razão como medida universal natural ${ }^{9}$ e comum das ações, isto é, como portadora dos fins últimos e universais que devem ser buscados e alcançados pelo homem, o que pretendemos mostrar que não é de fato coerente com o posicionamento de nosso autor.

natureza jamais se modifica. A instabilidade das paixões e a falta de uma regra comum que possa estabelecer parâmetros naturais de convivência pacífica deixam, como única alternativa para a paz, a construção de uma linguagem convencional e artificial. E, nesse sentido, a linguagem é um dos aspectos que possibilita a criação de pactos e do contrato necessário para se estabelecer artificialmente a paz. Assim, o papel da linguagem na filosofia hobbesiana é, grosso modo, oferecer uma ferramenta que permita ao homem estabelecer "variáveis" comuns e estáveis que possam ser calculadas pelo raciocínio humano, pois apenas através da estabilidade dessas variáveis é possível construir e estabelecer as bases necessárias para o contrato. E após o contrato estabelecer medidas do que é bom, mal, justo, injusto, fazer ciência e filosofia, e conservar a vida.

8 Ainda que possa ser postulada a existência de alguns traços específicos de distinção entre razão e recta ratio no interior da obra hobbesiana, é possível, sem prejuízo de interpretação do conceito, entender tanto razão como recta ratio como cálculo de nomes ou fatos.

9 Toma-se aqui por medida universal natural, aquela que serve de parâmetro capaz de produzir algum tipo de acordo comum entre os homens antes mesmo da construção do Estado soberano. 
Há, tanto no Leviatã como em Do Cidadão, algumas passagens que poderiam sustentar uma razão que seja naturalmente medida universal, isto é, que ponha fins e que forneça parâmetros comuns de justiça e bem no estado de simples natureza. Ao dizer, por exemplo, que a ciência da lei de natureza é a verdadeira e única filosofia moral (idem, p.136), ou ainda, ao afirmar que ela é um "preceito ou regra geral, estabelecido pela razão, mediante o qual se proíbe a um homem fazer tudo o que possa destruir sua vida" (Hobbes, 1998, p.112), Hobbes parece oferecer argumentos que sustentem a posição de que a razão é uma medida natural dos valores e da justiça comum. Ainda nessa mesma direção, ele chega a dizer que as leis de natureza são imutáveis e eternas (Hobbes, 2003, p.136). Ao tomarmos essas passagens, parece ser possível entender a filosofia de Hobbes como defensora da recta ratio no sentido de uma razão que põe fins, ou seja, que expressa o que seriam a virtude e a moralidade natural universal. ${ }^{10} \mathrm{E}$, nesse sentido, estariam certos aqueles que defendem uma moralidade natural universalizante que possa ser padrão de medida comum do bem e do mal, do justo e do injusto, do certo e do errado, antes mesmo da construção do Estado soberano. É nessa linha que intérpretes como Leo Strauss, A.E. Taylor e H. Warrender comentam a obra hobbesiana, ou seja, segundo esses autores (que trabalharemos de forma mais acurada no capítulo 2 desse trabalho) existiria uma espécie de imperativo moral (do tipo kantiano para Taylor, fundado na experiência da vaidade tipicamente humana para Strauss, e amparado em imperativos divinos para Warrender) antes mesmo do estabelecimento do corpo político. No entanto, não parece ser esse o caminho seguido por nosso autor quando se observa um pouco mais de perto a letra do texto hobbesiano.

Parece não ser possível compreender a razão como um parâmetro natural e universal da moral humana, já que não existe medida que

10 A compreensão do que é moral natural universal segue a mesma trilha do que se entende por medida universal natural, ou seja, é aquela regra moral capaz de servir de medida comum capaz de produzir algum tipo de acordo entre os homens antes mesmo da construção do corpo político. 
possa amparar qualquer julgamento no estado de simples natureza, pois as noções de certo e errado, de justiça e de injustiça não podem aí ter lugar.

Onde não há poder comum não há lei, e onde não há lei não há injustiça. Na guerra, a força e a fraude são as duas virtudes cardeais. A justiça e a injustiça não fazem parte das faculdades do corpo e do espírito. Se assim fosse, poderiam existir no homem que estivesse sozinho no mundo, do mesmo modo que seus sentidos e paixões. São qualidades que pertencem aos homens em sociedade, não na solidão (idem, p.111, grifo nosso).

Contudo, ainda poderia restar um questionamento no sentido de pôr à prova essa tentativa de mostrar que a recta ratio hobbesiana desempenha um papel fundamentalmente instrumental e calculador, ou seja, de uma razão que propõe meios e não fins. ${ }^{11}$ Como vimos acima, Hobbes chega mesmo a dizer que as leis de natureza constituem a verdadeira filosofia moral cujas regras são imutáveis e ao mesmo tempo diz que não há medida natural do justo e do injusto. Portanto, temos aqui duas premissas:

(1) Não há medida racional natural do que é bom, mal, justo e injusto.

(2) As leis de natureza são regras ou ditames da razão, imutáveis e eternas.

Poderíamos, então, entender isso como uma contradição interna ao próprio texto de Hobbes? Tal formulação parece deixar evidente que haveria uma incompatibilidade nas duas afirmações sustentadas, já que uma parece descrever uma medida racional natural e universalizante e a outra, a inexistência dessa medida. Contudo, essa aparente aporia pode ser desfeita quando se nota que a razão pode sim indicar ao homem como ele deve proceder para alcançar a paz como meio para preservação, pois "a razão sugere adequadas normas

11 Sobre essa abordagem Cf. Frateschi, 2003, p.123 ss. 
de paz, em torno das quais os homens podem chegar a um acordo" (idem, p.111, grifo nosso). Porém, a razão é suscetível a falhas em seu cálculo e isso ocorre "não porque a razão em si própria não seja sempre razão reta, assim como a aritmética é sempre uma arte infalível e certa. Mas [porque] a razão de nenhum homem, nem a razão de que número for de homens, constitui a certeza" (idem, p.40). Por isso, ainda que o homem alcance a compreensão das leis naturais isso não é garantia que ele as cumprirá, pois a natureza sempre induz os homens a seguirem suas paixões imediatas. No conflito natural entre as paixões e a razão, a natureza humana invariavelmente decide em favor da primeira, isso porque "em geral as paixões humanas são mais fortes do que a razão” (idem, p.160).

Podemos, sim, dizer que as leis de natureza oferecem uma medida para o julgamento do certo e do errado, do justo e do injusto, do bem e do mal. Contudo, essa medida será aplicada pelo julgamento individual de cada um no estado de simples natureza, e como vimos acima, "a razão de cada um não é infalível" e por isso, ainda que a natureza ofereça essa medida, sua aplicação individual não gera acordo natural. Será o cálculo individual, o juízo de cada um, que arbitrará acerca das questões que geram disputa, e isso faz que o estado de tensão natural permaneça no horizonte do estado de natureza mesmo considerando a existência de uma lei natural, pois essa lei natural não impõe seu cumprimento no sentido de uma obrigação natural, ela apenas "sugere normas adequadas" para a conduta humana. Isso parece de forma clara, por exemplo, quando Hobbes diz que: "O roubo, o assassínio e todas as injúrias são proibidos pela lei de natureza; mas o que há de se chamar roubo, assassínio ou injúria a um cidadão não se determinará pela lei natural, mas pela lei civil” (Hobbes, 1998, p.112). O que leva a entender que existe, sim, injúria no estado de simples natureza assim como existe o bem e o mal, o certo e o errado, porém, como é direito fazer uso de todos os meios para preservar-se a vida, em uma disputa pelos meios necessários para a manutenção da vida, cada um é juiz de seus próprios atos, assim, o que um indivíduo julgar como injúria, mal, errado etc. o outro pode legitimamente não julgar, de modo que apenas a lei civil 
constituída pelo poder soberano poderá justamente arbitrar de forma comum e universal acerca dessas questões.

Parece claro que Hobbes entende que existe uma razão que indica, descreve e constitui "juízos valorativos", no entanto, o que também parece claro é que esses "juízos de valor” postulados pela razão não possuem condições de se fazer valer de forma comum e universal, ou seja, não é o caso de dizer que não há julgamentos acerca do certo e do errado, do justo e do injusto no estado de natureza hobbesiano. O que parece, sim, ser o caso é de que há uma incapacidade da razão individual (que nada mais é que cálculo de nomes) promulgar por ela mesma um padrão moral universalizante, isto é, uma medida natural comum que seja suficiente para produzir qualquer tipo de acordo coletivo que anteceda o corpo político. A moral tomada como filosofia moral ou ciência moral que oferece as medidas, os padrões e a universalidade necessária para a vida em sociedade só existe dentro do Estado soberano, de tal modo que oferecer essa medida é uma das tarefas cardeais do corpo político conforme deixa claro o texto do Leviatã que diz que o papel do Estado consiste em "dotar os homens de lentes prospectivas (a saber, ciência moral e civil) que permitem ver de longe as misérias que os ameaçam [...]", e que, segundo Hobbes, "sem [o Estado civil soberano] não podem ser evitadas" (Hobbes, 2003, p.158, grifo nosso). Além do que, sempre que colocada frente a frente com as paixões, a razão irá se mostrar ineficaz, e nesse sentido, ainda que seja imutável e eterna, ela não conseguirá imprimir no homem a necessidade de seu cumprimento.

Para que as leis naturais sejam cumpridas conforme dita a recta ratio, será necessário um aparato jurídico forte que possa manter os homens em paz, ou seja, somente com o pacto e a criação do Estado político é que a razão poderá calcular os meios mais eficazes para manter os homens em um convívio minimamente pacífico. A própria natureza não oferece os meios necessários para que a paz seja contruída sem a necessidade de um artifício, isto é, sem que as bases para um acordo comum sejam postuladas externamente. Buscar os fundamentos da paz na investigação de uma moral universalizante que seja capaz de manter naturalmente os homens em convívio 
pacífico, mostra-se uma tentativa pouco provável se levarmos em consideração o que foi dito até aqui. Hobbes deriva sua filosofia moral da consideração da filosofia natural, e o que resulta necessariamente dessa concepção é um esvaziamento do conteúdo moral tomado como atribuição de valores universais a fatos ou condutas. O que resulta dessa abordagem mecânica e matematizante da natureza são julgamentos valorativos individuais que são incapazes de fornecer padrão ou medida natural universal.

O objetivo de Hobbes é elevar a filosofia ao patamar que as ciências ditas "matemáticas" atingiram, pois assim como os "aritméticos ensinam a adicionar e a subtrair com números, os geômetras com linhas, figuras, ângulos [...]. Os lógicos ensinam o mesmo com consequências de palavras [...]. Os escritores de política somam pactos [... [e] os juristas leis e fatos [...]" (Hobbes, 2003, p.39, grifo do autor). "Em suma, seja em que matéria for que houver lugar para a adição e para a subtração, também haverá lugar para razão, e, se não houver lugar para elas, também a razão nada terá a fazer" (idem). Essa "apropriação" de métodos matemáticos como ferramenta privilegiada para explicar a lógica funcional do discurso racional pode ser vista como mais um indício de que a proposta de Hobbes circula no âmbito da tentativa de aproximar o mais possível a filosofia natural à filosofia moral e política. É, nesse sentido, que parece ser viável sustentar a relação existente entre a ciência tomada do ponto de vista da física e a explicação do funcionamento humano e político, de tal forma a privilegiar dois conceitos fundamentais nesse processo, quais sejam, o de movimento e de corpo.

\section{Movimento e corpo como princípios}

No quadro das ciências presente no capítulo IX do Leviatã, a geometria, a física e a ética (estudo dos movimentos da mente) são áreas do saber que se situam no âmbito da filosofia natural, ou seja, são tratadas como partes da investigação acerca dos corpos naturais, ao passo que a política, por sua vez, situa-se no âmbito da filosofia 
civil onde se trata dos corpos artificiais. Aqui não trataremos de geometria, que é o estudo das questões relativas à definição de lugar (que é o espaço ocupado ou preenchido por um corpo); nem da definição do que é uma linha que é produzida pelo movimento de um ponto, ou que superfícies são produzidas pelo movimento de uma linha, etc. Essas questões não serão desenvolvidas neste trabalho, pois estarão aqui como ponto de partida pressuposto.

Para as pretensões deste trabalho, será necessário desenvolver brevemente o que se entende por teoria do movimento, que nada mais é que "um contínuo abandono de lugar e aquisição de outro" ${ }^{12}$ (Hobbes, 1966d, p.109), isto é, aquilo que se mostra aos nossos sentidos como aparência de movimento, pois "não há concepção no espírito do homem que primeiro não tenha sido originada, total ou parcialmente, nos órgãos dos sentidos" (Hobbes, 2003, p.15). É nessa direção que se deve entender que toda aparência de mudança que ocorre em um determinado corpo ${ }^{13}$ pode ser chamada de movimento, e também pode se entender que as coisas mais universais de cada espécie são conhecidas por si mesmas e não necessitam de método, pois possuem uma única causa ${ }^{14}$ universal que é o movimento. E por ser uma causa universal, isto é, uma causa que se aplica a todos os corpos existentes, a variedade das figuras, das cores, dos sons etc. o movimento não possui outra causa que não seja o próprio movimento que reside em parte nos objetos e em parte em nós mesmos, muito embora "não nos seja possível, sem o raciocínio, chegar a saber qual tipo" (Hobbes, 1966, p.70). Esse movimento que alguns não conseguem entender "até que lhe seja de algum modo demonstrado" (idem) é visto como

12 Motion is a continual relinquishing of place and acquiring another (Hobbes, 1966d, p.109).

13 "Corpo é aquilo que não depende de nosso pensamento e que coexiste ou coincide com alguma parte do espaço". "Body is that, which having no dependance upon our thought, is coincident or coextended with some part of space" (Hobbes, 1966d, p.103).

14 "Causa inteira é o agregado de todos os acidentes dos agentes e do paciente tanto quanto eles sejam, tomados conjuntamente". "Entire cause, is the aggregate of all the acidents both of agents how many soever they be, and of the pacient, put together" (Hobbes, 1966d, p.121-2). 
aparência de movimento, contudo, essa aparência é causada pela ação do próprio movimento. Portanto, para entender o que Hobbes nomeia como movimento é preciso investigar:

os efeitos produzidos pelos movimentos das partes de um corpo, do ponto de vista de como pode ocorrer que coisas, permanecendo as mesmas, pareçam, contudo, não serem as mesmas, mas alterar-se (idem, p.72). ${ }^{15}$

Essa alteração deve ser investigada a partir da relação de causa e efeito viabilizada pelo movimento, pois essa é a única maneira que podemos perceber que há um determinado movimento que age no corpo ou sobre um corpo. A própria relação de causalidade é apreendida pelo sujeito como aparência de causalidade, do que se pode inferir que perceber os efeitos causados pela ação do movimento de um corpo sobre outro corpo é entender que, por detrás dessa aparência de movimento, existe um movimento que de fato atua sobre um determinado corpo, mas que nos é dado conhecer apenas sua aparência. Explicitar essa relação é uma das grandes preocupações de Hobbes, pois ela permite mostrar que a percepção de um efeito qualquer é o que habilita um indivíduo a dizer que tal movimento atua sobre determinado corpo, e a relação causal que preside esse processo é esclarecida por Hobbes através do exemplo do fogo que aquece a mão de quem dele se aproxima (idem, p.121). ${ }^{16}$ O que está

15 Pode-se entender a origem das paixões humanas, que analisaremos no terceiro capítulo deste trabalho, a partir da consideração da ciência hobbesiana, mais propriamente, a partir da relação desses efeitos produzidos pelo movimento de um corpo. Apenas como consideração preliminar, pode se dizer que as paixões surgem da relação de um corpo (paciente) que sofre (suffer, por isso paciente, passivo, padecer, passion) a ação de outro corpo (agente), ou seja, a paixão surge da relação entre o movimento dos corpos. Analisaremos esse processo no capítulo 3 .

16 O único meio do qual se pode utilizar para alcançar algum tipo de conhecimento é a aparência sensível. Pois, o movimento presente nos corpos, e que é a causa de seus acidentes, só pode ser percebido pelos sentidos e nomeado por nós. $\mathrm{O}$ termo gerado (generated) traduz a ideia de causalidade de forma mais clara do 
presente nesse processo causal em que "toda mudança consiste somente em movimento" (idem, p.123-4) é o fato de que aquilo que muda em um corpo, isto é, seus acidentes, ${ }^{17}$ é apenas aquilo que é percebido por nós agora de forma diferente do que era percebido anteriormente. Portanto, mais do que oferecer um modelo explicativo para o processo causal, a percepção é ela mesma parte do processo, de modo que um movimento só será percebido quando os acidentes do corpo observado se mostrarem ou se apresentarem de forma diferente aos sentidos daquele indivíduo que o observa.

Esses acidentes de um corpo são aquilo que especificam determinado corpo e que, quando removido, leva-nos a pensar que o próprio corpo foi removido, porém o corpo ainda permanece no mesmo espaço. Desse modo, ainda que alguns acidentes pereçam com o corpo ao qual pertencem, deve se ter claro que eles são coisas distintas do próprio corpo. Um corpo é algo que persiste por si mesmo, é algo cuja "existência não depende de nosso pensamento e coincide e coexiste com alguma parte do espaço” (idem, p.102). ${ }^{18}$ Já os acidentes são a maneira com que se concebem esses corpos (idem, p.104). ${ }^{19}$ Os acidentes são a forma de perceber as especificidades de um corpo, suas singularidades, e, dessa forma, nomeá-los de acordo com essa percepção, em outras palavras, os acidentes são as características de um corpo que permitem ao sujeito que as observa especificar o corpo observado.

que o termo transmitido. O exemplo de Hobbes é claro: "quando a mão, ao ser movida, move a pena, o movimento não sai da mão para pena [...] mas um novo movimento é gerado na pena, um movimento que é da própria pena". "When the hand, being moved, moves the pen, motion does not go out of the hand into the pen [...] but a new motion is generated in the pen, and is the pen's motion" (Hobbes, 1966d, p.117, grifo nosso).

17 "Eu defino um acidente como a forma (manner) de nossa concepção de corpo". "I define an accident to be the manner of our conception of body" (idem, p.104). Contudo, Hobbes salienta que os acidentes são mais facilmente explicados através de exemplos do que por definições (idem, p.102).

18 "a body is that, which having no dependance upon our thought, is coincident or coextended with some part of space" (idem, p.102).

19 "I define accident to be the manner of our conception of body" (idem, p.104). 
Desse modo, para entender a distinção entre o que pode ser considerado corpo e o que pode ser tido como acidente deve ser pensado nos seguintes termos: os acidentes podem ser gerados e destruídos, os corpos não. Isso ocorre, por exemplo, quando se nomeia uma árvore ou qualquer outra criatura viva, o que se faz nesse caso é nomear apenas os acidentes que podem ser gerados e destruídos. Contudo, a magnitude de alguma coisa a que pode ser dada o nome de corpo não é gerada nem destruída. Assim, pode-se imaginar na mente a existência de um corpo onde antes não havia nada, e também o contrário, ou seja, imaginar um nada onde antes havia um corpo. Porém, é impossível imaginar como tal fato ocorre na natureza, de tal modo que aceitar a existência de acidentes necessariamente pressupõe a existência de um corpo.

A alteração dos acidentes de um corpo obedece a duas regras básicas da física hobbesiana:

(1) Se um corpo estiver em repouso ele permanecerá em repouso a menos que sofra a ação do movimento de outro corpo que o coloque em movimento. ${ }^{20}$

(2) Um corpo que está em movimento permanecerá em movimento a menos que sofra a ação contrária do movimento de um outro corpo. ${ }^{21}$

Essas duas regras norteiam todo processo de mudança no movimento de um corpo qualquer, seja ele natural ou artificial, por isso é possível, em última instância, afirmar que a relação de causalidade é uma dinâmica contínua de geração de movimentos entre os corpos, de sorte que cada movimento presente em um corpo determinado pressupõe a existência de movimento em um corpo anterior que o produziu. E é por meio desse processo que será possível especificar cada corpo particular com um determinado nome, pois são os acidentes dos corpos que permitem identificá-los, já que não há nada

20 "Whatsoever is a rest, will always be at rest, unless there be some other body besides it, which, by endeavouring to get into its place by motion, suffers it no longer to remain at rest" (Hobbes, 1966d, p.115). Cf.tb Hobbes, 2003, cap. 2.

21 "Whatsoever is moved, will always be moved, except there be some other body besides it, which causeth it to rest" (idem, p.115). Cf. tb Hobbes, 2003, cap. 2. 
em um corpo que possa ser considerado como sua essência ${ }^{22}$ ou substância primeira em um sentido ontológico. Todas as suas determinações são sempre determinações do movimento presente no corpo naquele momento. ${ }^{23}$ Nesse sentido, pensar as características específicas de um corpo é o mesmo que pensar nomes específicos que possam significar o que aparenta acontecer com determinado corpo, em outras palavras, tudo o que se diz ser específico de um corpo nada mais é do que nomes com os quais pode se designar tais e tais acidentes desse corpo.

Nesse contexto, pensar a identificação (essência) de um corpo é o mesmo que pensar sua forma, ou seja, a identidade de um corpo qualquer, inclusive do homem, deve ser compreendida por meio de suas qualidades formais. Assim, por exemplo, a essência de um homem é sua racionalidade, do mesmo modo que a brancura é a essência de uma coisa branca, a extensão é a essência de um corpo (idem, p.117).

Os conceitos de matéria e forma distinguem-se na obra de Hobbes basicamente pelo fato de que a forma possui um estatuto superior se comparada à matéria. Isso ocorre pelo fato de que a matéria é considerada apenas pela extensão, e a forma, por sua vez, distingue-se dos demais acidentes já que é o único através do qual podemos pensar a identidade de um corpo, os demais acidentes apenas permitem dizer que o corpo mudou, mas não que ele foi gerado, assim "a mesma essência, visto que é gerada, é chamada de forma” (idem, p.117) ${ }^{24}$ Contudo, ainda que a forma seja um acidente que distingue um corpo, ou

22 Aquele acidente ao qual damos nome a um corpo, ou o acidente que denomina um sujeito é comumente chamado de essência. Now that accident for which we give a certain name to any body, or the accident which denominates its subject, is commonly called the essence (Hobbes, 1966d, p.117)

23 Limongi afirma: "É preciso distinguir entre o corpo pensado genericamente, sem consideração de suas diferenças, como matéria ou sujeito de atribuição de acidentes (movimentos), e o corpo pensado especificamente como sujeito de qualidades distintivas. Esta distinção é, antes de mais nada, nominal, uma distinção entre duas categorias de nomes pelos quais designamos os corpos" (Limongi, 1999, p.23).

24 "And the same essence, in as much as it is generated, is called the FORM" (Hobbes, 1966d, p.117, grifo do autor). 
seja, que caracteriza sua essência, ainda assim ela nada mais é que movimento em um corpo específico tal como todos os demais acidentes. ${ }^{25}$

Portanto, temos duas razões básicas que asseguram à forma o estatuto de único acidente capaz de caracterizar a essência de um corpo:

Primeira razão: (1) A forma (que é um acidente) distingue um corpo por sua característica específica (por exemplo, um navio possui uma forma que o caracteriza como corpo próprio para navegação) e a matéria designa um corpo apenas pelo atributo da extensão.

Segunda razão: (2) A única maneira de nomear corretamente a essência de um corpo é através de sua forma. Os demais acidentes não permitem pensar a identidade de um corpo, pois estão sujeitos a contínuas mudanças e não podem garantir o princípio de identidade, que é formal. Contudo, a diferença entre a forma (que designa a essência), e os demais acidentes, é meramente nominal.

Nesse sentido, pensar a essência de um corpo no vocabulário propriamente hobbesiano, nada mais é que pensar "aquele acidente no qual damos um certo nome a algum corpo, ou aquele acidente que denomina um sujeito" (idem, p.117). ${ }^{26}$ Deste modo, para pensar conceitos tais como essência, forma, matéria, acidentes, etc. no âmbito da filosofia de Hobbes é preciso levar em conta a redefinição semântica que tais conceitos adquirem sob sua pena. Essa redefinição ou ressignificação é que permite ao filósofo inglês criticar a tradição escolástica ainda vigente intramuros nas universidades inglesas do séc. XVII. Ele adota um vocabulário já consagrado, porém não mais amparado na linguagem metafísica tradicional, mas sim em uma linguagem nominalista de caráter mecanicista.

25 Os conceitos de forma, matéria, acidente, essência entre outros, possuem no interior da filosofia hobbesiana uma carga semântica distinta daquela que a tradição filosófica de sua época, fundamentalmente aristotélica, assegurava e ensinava como linguagem filosófica comum. Sobre essa ressignificação dos conceitos da tradição aristotélica por Hobbes, cf. Spragens, 1973, p.97 ss.

26 Ainda Limongi (1999, p.27) "É, portanto, no interior de uma teoria que faz do movimento a causa primeira de todas as determinações dos corpos, mesmo as ditas essenciais, e não de uma ontologia que procura na substância a razão de suas determinações, que se deve entender a noção hobbesiana de essência". 


\section{A relevância do Método e a relação entre Ciência e Moral}

Em Hobbes, para se medir a solidez e a sustentação de uma afirmação, deve se submetê-la ao cálculo (raciocínio) rigoroso de suas premissas e conclusões, pois um argumento só será sustentável se seu encadeamento interno for construído com método. O uso de um método rigoroso é a garantia de alcançar o conhecimento com mais retidão, ou seja, conhecer as causas a partir dos efeitos ou os efeitos a partir das causas.

Se a filosofia é o conhecimento alcançado pelas aparências ou efeitos aparentes por meio do verdadeiro raciocínio (Hobbes, 1966, p.65), o método, por sua vez, no estudo da filosofia "é o caminho mais curto para descobrir os efeitos por suas causas conhecidas ou as causas por seus efeitos conhecidos" (idem). E o método em Hobbes pode ser tanto analítico quanto sintético, porém, é importante ressaltar, não se trata de dois métodos mas sim de dois modos de aplicação de um mesmo método. Porém, antes de mostrarmos o motivo dessa constatação, é preciso entender brevemente qual a distinção entre esses dois modos de aplicação do método proposto por Hobbes.

O modo sintético é aquele que parte das definições dos conceitos a serem utilizados em uma construção argumentativa de modo a unilos posteriormente produzindo um discurso. Quando se considera a obra de Hobbes, seguir a via metodológica significa partir da filosofia primeira e da geometria, depois da física, e só após a consideração dessas áreas do saber, deve-se procurar entender a moral e a política. Contudo, para alcançar o conhecimento das coisas tanto vale começar pelas definições (modo sintético-compositivo), isto é, partir das causas para entender os efeitos, como se pode iniciar pela consideração dos efeitos (modo analítico-resolutivo) e, a partir de então, procurar suas causas analisando cada parte que compõe o objeto investigado.

Como foi mostrado anteriormente, o movimento é um conceito chave na construção teórica hobbesiana, e nesse sentido a consideração acerca do método (seja sintético ou analítico) sempre levará a indicação da prevalência desse conceito em relação aos outros. No que 
se refere à aquisição de conhecimento tanto o modo sintético quanto o analítico são eficazes para levar a investigação a um bom termo. Portanto, se por um lado pode se produzir conhecimento a partir de definições dos nomes a serem utilizados no discurso e a partir do cálculo dessas definições, por outro lado, partir da investigação do meio em que o homem está inserido e de suas experiências pessoais também pode fazer que se produza conhecimento, ou seja, ao se investigar a semelhança dos pensamentos e paixões de um homem com os pensamentos e paixões de outro, se pode "ler e conhecer quais os pensamentos e paixões de todos os outros homens" (Hobbes, 2003, p.12-3).

Portanto, não são apenas aqueles que atingiram o conhecimento das paixões e perturbações da mente pelo método sintético, e a partir dos genuínos princípios da filosofia, que podem, procedendo do mesmo modo, chegar às causas e à necessidade de construir Estados, e obter conhecimento do que é direito natural e o que são os deveres civis $[\ldots]$ e isto pela seguinte razão, que os princípios da política consistem no conhecimento dos movimentos da mente, e o conhecimento desses movimentos, do conhecimento dos sentidos e da imaginação; mas mesmo aqueles que não estudaram a primeira parte da filosofia, a saber, a geometria e física, também podem, não obstante, alcançar os princípios da filosofia civil pelo método analítico. (Hobbes, 1966, p.73-4, grifo do autor) ${ }^{27}$

Assim, não é necessário partir de definições de nomes para se chegar à necessidade da construção do corpo político. É possível

27 "And, therefore, not only they that have attained the knowledge of the passions and perturbations of the mind, by the synthetical method, and from the very first principles of philosophy, may by proceeding in the same way, come to the causes and necessity of constituting commonwealths, and to get the knowledge of what is natural right, and what are civil duties...; for this reason, that the principles of the politics consist in the knowledge of the motions of the mind, and the knowledge of these motions from the knowledge of sense and imagination; but even they also that have not learned the first part of philosophy, namely, geometry and physics, may, notwithstanding, attain the principles of civil philosophy, by the analytical method" (Hobbes, 1966d, p.73-4, grifo do autor). 
chegar a essa necessidade pela observação do meio de inscrição de nossas paixões e do contexto em que elas se inserem.

Contudo, os conceitos mecânicos estão presentes na construção disso que chamamos de método, tanto na via sintética quanto na via analítica. Ainda que Hobbes possa dizer que "a filosofia civil e a filosofia moral não aderem tanto uma à outra que não possam ser separadas" (idem, p.73), isso não significa que não exista uma relação entre o modelo mecânico de construção da argumentação em um discurso e a elaboração argumentativa da filosofia civil ou política. Se, por um lado, Hobbes pode dizer que a ciência mecânica e a política "não aderem tanto", por outro lado ele não pode dizer que eles "não aderem de modo algum".

Se no quadro das ciências exposto no Leviatã Hobbes entende a ética como derivada dos estudos dos corpos naturais, ou seja, da física, e por outro lado, entende a política (único campo em que podemos avaliar as ações dos homens sob uma regra universal de valoração moral) como derivada dos estudos dos corpos artificiais, isso não significa que a argumentação que expõe a necessidade de se construir Estados seja diversa daquela usada para entender as questões relativas ao estudo da ética. O rigor geométrico e o uso de analogias com conceitos físicos depõem a favor de uma aproximação entre o estudo dos corpos artificiais (Estado) e o estudo dos corpos naturais e consequências das paixões da mente (ética) sempre tendo como pano de fundo a ciência de caráter mecanicista. ${ }^{28}$

Assim, seja analítico, seja sintético, partindo da experiência ou da construção de definições, se o método for rigoroso então pode se chegar aos efeitos ou às causas procuradas. No entanto, a relação entre a física, a filosofia moral e a filosofia política não é uma visão

28 Na obra Politics of Motion, Thomas Spragens diz que a mecânica de Hobbes "exerce profundo impacto sobre a política por meio de analogias...e na filosofia natural, Hobbes desenha um modelo de comportamento que é transportado (...) para sua explicação do comportamento humano, tanto político quanto psicológico. O modelo criado para a interpretação da natureza tem ressonância em algumas das partes fundamentais da política, especialmente nas que tratam das paixões humanas" (Spragens, 1973, p.166, grifo nosso). 
aceita por todos os intérpretes da obra de Hobbes, ao contrário, essa é uma das querelas que mais suscitam discussões entre aqueles que se debruçam no estudo do pensamento do autor de Malmesbury. Isso ocorre por vários motivos e distintas interpretações, o que nos parece ser o ponto mais sólido em que essas interpretações buscam se sustentar é a passagem do Do Cidadão em que Hobbes diz que a proposta inicial de construção de sua obra se daria da seguinte forma: (1) Começar pela filosofia primeira e os elementos da física; (2) Discutir a imaginação, a memória, o intelecto, o raciocínio, os apetites, o bem e o mal, etc. (3) Discutir os princípios da política (Hobbes, 1998, p.18). No entanto, por razões ainda discutidas pelos comentadores, Hobbes começou pela última parte, ou seja, pela elaboração de uma teoria política, que poderia ser levada a cabo independentemente das outras partes de sua obra, já que a política "fundada em seus próprios princípios suficientemente conhecidos pela experiência, não precisaria das partes anteriores" (idem).

Tal afirmação parece mostrar que a política possui independência com relação à consideração da filosofia natural, o que um grande número de intérpretes também sustenta, com base nessa passagem é que Hobbes estabelece uma distinção radical entre filosofia natural e filosofia civil, ou seja, a julgar exclusivamente por esse trecho da obra, não haveria nenhuma ligação entre o estudo dos corpos naturais e o estudo dos corpos artificiais, e isso permitiria a Hobbes falar da necessidade da construção do Estado civil soberano (corpo artificial) sem se remeter a questões relativas à ciência e à filosofia natural.

É nessa perspectiva que autores como Leo Strauss tentam explorar a independência interna da filosofia moral e da política com relação aos princípios da física, e ainda com o intuito de mostrar essa mesma independência, porém sustentada sobre outras bases, A.E. Taylor e H. Warrender, cada qual a sua maneira, buscam alinhar Hobbes a uma outra perspectiva que não a de uma relação entre as partes da obra de modo a privilegiar um pano de fundo mecanicista.

Porém, antes de tentarmos entender a proposta de leitura desses autores, é importante marcarmos o campo metodológico em que se move a produção intelectual de Hobbes, pois ainda que ele deixe claro 
que mesmo aqueles "que não estudaram a primeira parte da filosofia, a saber, geometria e física, também podem, não obstante, alcançar os princípios da filosofia civil pelo método analítico" (Hobbes, 1966, p.74). ${ }^{29}$ Nota-se que o próprio Hobbes em sua obra teve sempre a preocupação de privilegiar o método sintético, ou seja, aquele que parte de definições de nomes. Os quadros de exposição da ciência construídos por ele deixam transparecer essa preferência metodológica, mesmo no De Corpore (1655), que foi publicado mais de dez anos após o De Cive (1642), Hobbes insiste em expor que o caminho seguido por ele foi o sintético, isto é, começar pela investigação dos princípios mais fundamentais, e por isso ele discorre primeiro "sobre os corpos naturais; em segundo lugar, sobre as disposições e costumes dos homens; e um terceiro, sobre os deveres civis dos súditos" (idem, p.12). ${ }^{30}$

O próprio argumento usado por Hobbes para sustentar que tanto a via analítica quanto a sintética são válidas para se atingir o conhecimento das causas e dos efeitos das aparências, parece deixar clara a relação existente entre a física do movimento dos corpos que parte de definições (portanto vale-se da via sintética) a filosofia moral e a política. Diz o autor que tanto uma via (sintética) quanto a outra (analítica) podem ser utilizadas já que ambas devem chegar ao conhecimento dos movimentos da mente, pois o movimento é a única causa universal, isso significa que o movimento é a única causa de si mesmo, pois "não pode ser entendido como tendo outra causa além do [próprio] movimento” (idem, p.69). ${ }^{31}$

Ora, o movimento é um conceito da física que está presente em toda a filosofia de Hobbes, e, nesse sentido, o que se torna relevante é que o método leve ao conhecimento desse princípio físico, seja a partir de definições, seja a partir da observação e da experiência. Portanto, conhecer um conceito físico e proceder mecanicamente é o

29 "but even they also that have not learned the first part of philosophy, namely, geometry and physics, may, notwithstanding, attain the principles of civil philosophy, by the analytical method" (Hobbes, 1966d, p.74)

30 "I will discourse of bodies natural; in the second, of the dispositions and manners of men; and in the third, of the civil duties of subjects" (idem, p.12).

31 "for they have all but one universal cause, which is motion" (idem, p.69) 
que garante o rigor do método na construção de um discurso. Desse modo, tanto no De Corpore, quanto no Do Cidadão e no Leviatã, Hobbes pode afirmar que, partindo da experiência (via analítica) ou de definições (via sintética), é possível chegar ao mesmo ponto, qual seja, a relação conflituosa das paixões naturais do homem (entendidas mecanicamente) que em algum momento necessariamente se transformarão em empecilho à perpetuação do movimento vital ${ }^{32}$ (vida) de seus semelhantes. Desse empecilho ou impedimento de agir conforme seu movimento vital, nasce a necessidade de proteger-se contra qualquer ataque possível, e a melhor forma de defender-se é não esperar o ataque alheio, mas ao considerar suas próprias forças, deve-se agir por antecipação.

E essa relação de constante tensão entre os homens pode também ser pensada em uma analogia com a consideração hobbesiana dos princípios que norteiam a natureza das coisas, isto é, dos princípios físicos. A analogia é simples: a guerra se dá pelo fato de que é possível pensá-la como um princípio físico e natural, ou seja, que todos os corpos tendem a perpetuar em seu movimento e a única forma disso não ocorrer é quando há algum corpo que impeça o livre fluxo desse movimento. E quando esse corpo se interpõe no caminho de um outro corpo eles necessariamente se chocam, e aquele que possui um movimento maior gera esse movimento no outro corpo. Assim, quando o caminho que leva à obtenção dos objetivos individuais de dois corpos se interpõe um ao outro é natural que eles entrem em guerra, não porque são maus ou egoístas, mas porque um está impedindo o livre fluxo do movimento do outro, e perpetuar o movimento é uma lei física e natural que rege todos os corpos, e não uma lei moral

32 Hobbes diz que existem dois tipos de movimentos no homem, o movimento animal e o movimento vital. $\mathrm{O}$ primeiro diz respeito àquelas ações voluntárias realizadas pelo homem e que necessitam do auxílio da imaginação, tal como andar, falar etc. Já o movimento animal é aquele que "começa com a geração e continua sem interrupção durante toda a vida. Deste tipo são a circulação do sangue, a pulsação, a respiração, a digestão, a nutrição, e excreção etc. Para esses movimentos não é necessária a ajuda da imaginação" (Hobbes, 2003, p.46. grifos do autor). 
universal tipicamente humana. ${ }^{33}$ De fato, o homem não é como um corpo "inanimado" qualquer, ele carrega (assim como os animais) a possibilidade de deliberar, isto é, calcular apetites e aversões antes de realizar uma determinada ação, porém entender a guerra pelo viés estritamente mecânico não é incompatível com o fato de que o homem é capaz de deliberar. Todos os corpos vivem sob a mesma lei mecanicista de funcionamento do mundo, contudo, o homem é um corpo que delibera, que possui vontade, que disputa e compete por poder e por glória, e essas características atuam como uma espécie de "agravante" que também faz que ele viva em constante estado de tensão, isto é, em uma situação de guerra permanente.

Note-se que, no estado de simples natureza, não há como impedir que um corpo se interponha ao movimento de outro corpo, pois é da própria natureza que todos têm direito a todas as coisas (Hobbes, 1998, p.32) $)^{34}$ e que, portanto, não há nenhum direito natural que possa ser reivindicado como razão para que se impeça qualquer movimento de um corpo. Nesse sentido, ser obstáculo e impedir o movimento de um outro corpo é algo que pode acontecer a qualquer momento, ainda que a ocorrência de tal fato não seja objetivo manifesto do indivíduo. E assim como é um fato natural que, em algum momento, um corpo possa impedir o livre fluxo do movimento de um outro corpo, também é um fato natural que, ao sofrer tal impedimento o indivíduo possui o direito de resistir a ele e de guerrear, se preciso for, para manter seu movimento.

33 Spragens mostra que Hobbes transporta a teoria do movimento para a teoria moral e política, e assim, entende que não apenas os corpos em geral, mas também os homens se movem inercialmente, de modo que não apenas seus movimentos físicos (externos), mas também suas emoções se movem sem fim e sem repouso. E ainda: "no mundo do movimento inercial, todas as coisas tendem a persistência; o homem, que é uma criatura natural, não constitui exceção" (Spragens, 1973, p.177).

34 A compreensão do direito de natureza como um fato da natureza segue a esteira da interpretação feita por Yara Frateschi: "Note-se que o direito de natureza é um fato da natureza: é tendência humana natural persistir na vida, e os homens agem naturalmente para preservá-la e para evitar a morte." (Frateschi, 2003, p.173, grifo nosso). 
Assim, o mesmo direito natural que dá ao homem o direito a todas as coisas também diz que devemos procurar a paz, isto é, quando possível e se possível, devemos calcular nossa conduta de modo a evitar ser obstáculo ao movimento de outros corpos, contudo, se tal cálculo não for possível, devemos e somos autorizados pelo direito natural a usar de todos os recursos da guerra para a própria defesa. Portanto, é um direito natural: "Que todo homem deve se esforçar pela paz, na medida em que tenha esperança de a conseguir, e caso não a consiga pode procurar e usar todas as ajudas e vantagens da guerra" (Hobbes, 2003, p.113). ${ }^{35}$

O que temos então é que a guerra ou a tensão constante e manifesta no estado de simples natureza não é efeito de uma atitude má tipicamente humana, mas sim do fato de que o homem vive sob a égide dos mesmos princípios que regem a natureza das coisas, isto é, dos princípios da filosofia da natureza.

Poderia aqui ser feita a seguinte objeção quanto ao que acabou de ser dito acima: se todos os corpos vivem sob a mesma lei, que é de base mecanicista, porque as abelhas e as formigas podem naturalmente viver em sociedade e apenas os homens vivem naturalmente em estado de guerra? Ambos são corpos, mas vivem de modos distintos, viveriam então também sob leis distintas? A resposta parece ser: não.

Hobbes mostra que as abelhas e as formigas vivem naturalmente em sociedade porque, diferentemente dos homens, elas não "estão constantemente envolvidas em numa competição pela honra e pela dignidade [...]. E é devido a isso que surgem entre os homens a inveja e o ódio, e finalmente a guerra, ao passo que entre aquelas criaturas isso não acontece" (idem, p.145-6). Ora, dizer que os homens naturalmente vivem em um estado de competição que leva à guerra e que

35 No Do Cidadão lemos: "A lei de natureza primeira e fundamental, é que devemos procurar a paz, quando possa ser encontrada; e se não for possível tê-la, que nos equipemos com os recursos da guerra" (Hobbes, 1998, p.38). E ainda, nos Elementos de Lei o mesmo direito é expresso nos seguintes termos: "que cada homem, para o seu próprio bem, procure a paz à medida que existir a esperança de consegui-la; também que se fortaleça com toda a ajuda que puder procurar, para a sua própria defesa contra aqueles com quem a paz não pode ser obtida" (Hobbes, 1969b, p.74). 
as abelhas naturalmente vivem em sociedade parece apontar para o fato de que não existe uma "cosmologia" que atue em todos os corpos naturais de forma semelhante. Portanto, não é possível estabelecer uma relação entre a física e as paixões humanas (filosofia da natureza e filosofia moral). Contudo, é preciso notar alguns aspectos que levam a esse comportamento distinto entre os homens e os animais ainda que eles vivam sob as regras da mesma filosofia da natureza.

Entre os animais não há diferença entre o bem comum e o bem individual (idem, p.146) de modo que a busca pelo bem individual leva ao bem comum, portanto, a busca do bem individual que é natural (tendência natural de perpetuar no movimento) trará o benefício comum, por isso, eles não vivem em guerra e não precisam de pactos para instituir a paz. Já entre os homens, a busca pelo bem privado não possui simetria com a busca do bem comum, pois a "alegria [do homem] consiste em se comparar, [e ele] só encontra felicidade na comparação com os outros homens, [e] só pode apreciar o que é eminente" (idem). Nesse sentido, o benefício individual necessário para a preservação da vida levará à competição por poder. E como a glória, a reputação de dignidade e a honra são mostras de poder, os homens vivem em guerra por disputar a prevalência dessas paixões. Já os animais como as abelhas e as formigas, por sua vez, vivem pacificamente em sociedade, pois não há entre elas disputas dessa ordem. Contudo, ambos, homens e animais, vivem sob o mesmo princípio da preservação do movimento, isto é, buscam a preservação da vida, porém esse princípio leva os homens à competição e à guerra, e os animais, graças à simetria entre o bem comum e o bem individual, vivem naturalmente em sociedade, já que a sociedade ao promover o bem coletivo naturalmente promove o bem individual.

Essa relação entre a explicação do comportamento humano, do funcionamento do Estado político e da mecânica das leis naturais pode ser encontrada em várias passagens na obra de Hobbes. Ainda na introdução do Leviatã é feita uma analogia entre a lógica de funcionamento dos autômatos (máquinas) e aquela que rege o corpo humano, de tal forma que as semelhanças são notáveis para o filósofo inglês. Sua argumentação, que segue a primazia do movimento dos corpos, considera que a vida nada mais é que o movimento 
dos membros do corpo, e diz ainda que todos os autômatos podem possuir vida artificial. Nesse sentido, a analogia ocorre de tal modo que o coração de um homem se assemelha a uma mola, os nervos a cordas, e as juntas a rodas (idem, p.11). O funcionamento do Estado segue essa mesma lógica, isto é, o Estado imita o homem, que é uma criatura racional e a mais excelente obra da natureza (idem), pois o que é o Estado Leviatã senão "um homem artificial, embora de maior estatura e força do que o homem natural, para cuja proteção e defesa foi projetado. E no qual a soberania é uma alma artificial, pois dá vida e movimento ao corpo inteiro" (idem).

Esse homem, cujo agir no mundo possui um funcionamento interno que é mecânico e que pode ser comparado a um autômato, vive naturalmente em estado de tensão e conflito, e essa tensão se dá graças ao desejo humano. O desejo (apetite) é uma paixão que leva os homens a agirem no sentido de alcançar um objeto de desejo particular (voltaremos a essa definição com mais calma adiante, mas por hora fiquemos com essa). Desta forma, quando se tem um apetite por um objeto qualquer que não pode ser desfrutado por todos nem mesmo dividido em comum, é uma consequência natural que a competição (guerra) se instale nesse momento. E uma vez instalada a guerra, é um direito natural de todo indivíduo que no estado de simples natureza o mais forte faça valer sua força para garantir a obtenção de seu objeto de desejo.

O apetite será sempre suscitado por um objeto externo que aparente trazer ou fazer bem àquele que deseja, e na busca da satisfação desse desejo todo homem está autorizado a fazer uso da força, quando for prudente e necessário. Contudo, mais uma vezé importante notar aqui que o desejo de conseguir aquilo que aparenta trazer o bem para si mesmo ${ }^{36}$ não é um traço moral propriamente humano, mas sim um

36 Esse "bem para si mesmo" é o que Yara Frateschi chama de "princípio do benefício próprio”. Segundo a autora, há em Hobbes um princípio, que pode ser provado tanto pelo método sintético como pelo analítico, de que "toda ação voluntária é feita visando à obtenção de algum benefício” de modo que a "intenção [de Hobbes] é provar, a partir da análise das causas da associação, que o homem é autointeressado e age primeiramente em função do seu próprio benefício" (Frateschi, 2003. p.23 ss). 
princípio fisicalista, pois "todo homem é desejoso do que é bom para ele, e foge do que é mal; [... ] e isso ele faz por um certo impulso da natureza, com tanta certeza como uma pedra cai”' (Hobbes, 1998, p.31).

Portanto, parece ser sustentável e coerente pensar que a ciência mecanicista possui um lugar privilegiado no interior da obra hobbesiana e, por isso, pensar a política e a moral como áreas do saber que podem ser independentes, pode significar uma leitura enviesada que não leva em consideração a letra do texto do autor inglês. Isso é o que pretende se mostrar a partir de agora com a consideração mais próxima de três autores consagrados na interpretação da obra hobbesiana, A.E. Taylor, H. Warrender e Leo Strauss, já mencionados.

$\mathrm{Na}$ visão de A.E. Taylor, o argumento principal para sustentar a não relação entre a política, a moral, e a física é sustentado numa leitura que afirma uma aproximação entre a teoria moral hobbesiana e uma teoria moral de matriz kantiana. Segundo ele, haveria em Hobbes a semente do que foi desenvolvido por Kant no tocante à moral, isto é, um princípio que seria anterior (a priori) ao Estado e que nortearia a ação do Homem no mundo.

Outra interpretação que segue a mesma linha de negação da relação entre física, moral e política é a de Leo Strauss. $\mathrm{O}$ autor alemão radicado nos E.U.A, no entanto, tem como argumento principal a tese de que há na filosofia de Hobbes um princípio moral que privilegia a experiência dos apetites naturais (especialmente a vaidade humana) como traço fundamental que leva os indivíduos ao conflito generalizado.

E, por último, porém não menos importante, pretende se observar que $\mathrm{H}$. Warrender, no intuito de criticar o mesmo ponto que os dois autores anteriores, mostra que há, sim, em Hobbes uma base moral. E para ele, o que pode dar à ação um aspecto moral universalizente é o fato de que toda lei moral é também uma lei divina, desse modo haveria em Hobbes uma ligação necessária não mais entre a física e a moral, mas sim entre a moral e as leis divinas. 



\section{2 \\ UMA ABORDAGEM CRÍTICA: TAYLOR, Strauss, WarRender}

\section{Taylor}

A abordagem de Taylor vê na obra de Hobbes semelhanças argumentativas e teóricas que, segundo o autor, antecipariam o que seria formulado mais tarde por Kant, ou seja, o que fundamentaria a filosofia do autor inglês seria uma base moral apriorística presente no homem que julgaria as ações humanas universalmente como justas ou injustas nelas mesmas, independentemente da existência ou não do corpo político.

Em seu artigo intitulado "The Ethical Doctrine of Hobbes" publicado em 1938, Taylor afirma haver na obra hobbesiana, especialmente na moral que lhe corresponde, uma forte semelhança com a doutrina moral kantiana. Ele justifica tal posição ao chamar a atenção do leitor para a distinção que é feita no De Cive quando Hobbes afirma que um homem justo e uma ação justa são coisas de naturezas distintas. Dessa forma, uma ação justa seria aquela feita de acordo com a lei, sem que isso signifique que o homem que atue de acordo com a lei seja necessariamente um homem justo.

ser justo significa o mesmo que deleitar-se em agir com justiça ou empenhar-se, em todas as coisas, por fazer aquilo que é justo; e ser 
injusto consiste em negligenciar o trato correto dos outros, ou em pensar que este deva ser medido, não em função do que contratei, mas de algum benefício imediato. De modo que a justiça ou injustiça da mente, ou da intenção, ou da pessoa, é uma coisa, e a justiça ou injustiça da ação, ou da omissão é outra. (Hobbes, 1998, p.56)

Nessa passagem, parece ser possível observar que Hobbes deixa espaço para uma interpretação que se direcione no sentido da existência de uma possível "justiça ou injustiça da mente", isto é, uma justiça que anteceda e seja independente do contrato. Porém, essa interpretação encontra um obstáculo na medida que é impossível ao homem vir a conhecer os designos internos dos outros homens, ou seja, é impossível fazer ciência daquilo que faz parte do fórum interno ${ }^{1}$ de cada indivíduo. Em outras palavras, é impossível fazer "ciência das intenções" de cada um.

Ao não levar em consideração essa impossibilidade, Taylor vê na passagem supracitada do Do Cidadão uma formulação que anteciparia de certa forma o argumento kantiano que distingue o agir por dever moral e o agir conforme o dever ou conforme a lei. Assim, haveria em Hobbes uma espécie de imperativo categórico de foro interno que, independente de qualquer móbil externo, dirigiria a ação moral do homem de tal modo que apenas aqueles que agirem de acordo com essa inclinação de foro interno é que poderiam ser chamados homens justos.

Com essa interpretação, Taylor assume que existiria na filosofia de Hobbes uma espécie de valor intrínseco aos objetos e aos fatos, ou seja, mesmo antes do pacto e da criação do Estado soberano haveria

1 Quando se diz que as leis naturais obrigam in foro interno, isso significa que tais leis "tornam impositivo o desejo de que sejam cumpridas; mais in foro externo, isto é, tornando impositivo o desejo de as colocar em prática, nem sempre obrigam” (Hobbes, 2003, p.136). Ou seja, a obrigação de colocar em prática o exercício da lei natural não deriva do desejo de seu cumprimento. A natureza impõe sim o desejo de cumprimento, mas não possui força capaz de obrigar que tais leis se cumpram, nesse sentido não é possível dizer que as leis obrigam de fato que os homens a sigam. Elas podem impor in foro interno o desejo de cumprimento, mas não a obrigação de externar tal desejo. 
condições naturais de realizar julgamentos acerca do bem e do mal, do justo e do injusto. Teríamos, portanto, as condições que possibilitariam ao homem arbitrar a esse respeito, pois como ele afirma, "A obrigação moral de obedecer a lei natural antecede a existência do legislador e da sociedade civil. Já no estado de natureza a lei obriga in foro interno" (Taylor, 1965, p.26). ${ }^{2}$ Para amparar tal posição, o autor busca no Leviatã a passagem em que Hobbes (2003, p.136, grifo nosso) diz:

Todas as leis que obrigam in foro interno podem ser violadas, não apenas por um fato contrário a lei, mas também por um fato conforme a ela, no caso de o seu autor o considerar contrário. Pois, embora neste caso a sua ação seja conforme à lei, a sua intenção é contrária à lei, o que constitui uma violação quando a obrigação é in foro interno ".

Desta forma, assim como em Kant, na filosofia hobbesiana a ação moral seria medida de acordo com a intenção do ator que a realiza, de modo que seu valor estaria presente na própria ação, intrínseco e imanente a ela. Uma das consequências que podem derivar dessa abordagem empreendida por Taylor é que a ética construída por Hobbes não possuiria nenhum tipo de relação com a mecânica característica de sua obra, ou seja, sua filosofia poderia ser tomada de tal forma que a ética é uma espécie de princípio fundamental, dado que as leis de natureza representam requisitos morais sobre os homens que não se fundamentam de modo algum na psicologia humana. Dessa abordagem decorre que, a teoria ética hobbesiana seria uma "deontologia estrita que, embora com algumas distinções, pode ser comparada com as teses características de Kant" (Taylor, 1965, p.23). Isto significa ainda que temos em Hobbes um princípio a priori fundado na racionalidade da lei natural que atua como sustentação do dever moral.

2 "The moral obligation to obey the natural law is antecedent to the existence of the legislator and the civil society; even in the 'state of nature' the law obliges 'in foro interno"” (Taylor, 1965, p.26). 
A solidez do argumento defendido por Taylor sustenta-se fundamentalmente na tese de que existe uma ideia ou ideal moral que é comum e que tem força para se fazer valer mesmo antes da viabilização do Estado civil. Contudo, esse posicionamento teórico só é possível, entre outras coisas, graças à não consideração de que a moral tomada pelo princípio da ciência mecanicista perde seu caráter universalizante na medida em que o princípio do movimento inercial (tendência a perpetuar no movimento) pode ser tomado antropologicamente como a busca natural de cada indivíduo pelo "benefício próprio". Por não fazer tal consideração, Taylor não pode entender que o desejo natural de acúmulo de poder (glória, boa reputação etc.) é o meio de se buscar o próprio bem, que por sua vez, é o meio de se preservar a vida (perpetuar o movimento). Porém, tal busca aliada ao desejo de poder e mais poder ${ }^{3}$ leva à competição individual pela aquisição desses meios necessários à preservação da vida. Para se sobressair nesse estado de competição (guerra de todos contra todos), "todo homem deve se esforçar pela paz, na medida em que tenha esperança de a conseguir, e caso não a consiga pode procurar e usar todas as ajudas e vantagens da guerra" (Hobbes, 2003, p.113) e, nesse estado, o justo e o injusto são decididos pelo arbítrio individual. No estado de natureza, isto é, na guerra, "a força e a fraude são virtudes cardeais [pois] as noções de certo e errado, justiça e injustiça, não podem aí ter lugar" (idem) assim, não há nada na natureza que possa ser tido como medida universal a não ser o arbítrio de cada indivíduo. E isso é derivado de uma consideração da preservação da vida como algo análogo à necessidade natural de todos os corpos em se perpetuarem no movimento. Tal análise é negada por Taylor, ou seja, ele não trabalha a possibilidade de relação entre a filosofia natural e a filosofia moral e política.

Ao analisar alguns aspectos da obra de Hobbes, contudo, é possível notar que, se não há uma relação de dependência estrita entre a mecânica e a moral política, é impossível negar que está presente em

3 "Assinalo assim, em primeiro lugar, como tendência geral de todos os homens, um perpétuo e irrequieto desejo de poder e mais poder, que cessa apenas com a morte" (Hobbes, 2003, p.85). 
toda a obra do filósofo de Malmesbury uma mecânica construída com bases em uma espécie de cosmologia física do movimento dos corpos. Negar essa hipótese, como faz Taylor, parece destoar daquilo que Hobbes diz na introdução do De Cive, em que descreve que inicialmente pretendia desenvolver sua filosofia em três partes, "de modo que na primeira trataria do corpo, e de suas propriedades gerais; na segunda, do homem e de suas faculdades e afecções especiais; na terceira, do governo civil e dos deveres dos súditos" (Hobbes, 1998, p.17).

No entanto, esse projeto não foi levado a cabo, pois na Inglaterra do séc. XVII as discussões acerca dos poderes políticos, do lugar a ser ocupado pelos súditos no governo, e das diretrizes governamentais em voga na época, fizeram que Hobbes adiasse seu plano inicial e começasse seu trabalho pela última parte, ou seja, pela política.

Taylor, assim como os demais autores que participam dessa mesma linha argumentativa, ao fazer sua análise acerca da ética hobbesiana parece não considerar esse projeto inicial proposto pelo filósofo inglês. Projeto esse que, mesmo impossibilitado de se realizar da forma com que foi calculado por seu arquiteto, ainda assim é significativo do ponto de vista da análise de toda sua obra, pois o primeiro movimento intelectual de Hobbes deveria se iniciar com a investigação dos corpos e de suas propriedades gerais, como citado acima. Esse propósito fica claro quando observamos o que Hobbes diz com relação ao procedimento que devemos adotar ao buscarmos o conhecimento, o caminho deve ser feito de tal modo a começar pela física e:

Após a física, devemos passar à filosofia moral, na qual consideraremos os movimentos da mente como apetite, aversão, amor, benevolência, esperança, medo, cólera, rivalidade, inveja, etc. que causas eles têm, e de que eles são causas. (Hobbes, 1966, p.72, grifo do autor) ${ }^{4}$

4 "After physics we must come to moral philosophy; in which we are to consider the motions of the mind, namely, appetite, aversion, love, benevolence, hope, fear, anger, emulation, envy etc; what causes they have, and of what they be causes". 
Para tentar esclarecer como se processa esse movimento na obra de Hobbes e tentar justificar uma posição no sentido de argumentar a favor da unidade da obra em torno do mecanicismo, é preciso fazer uma breve incursão pelos conceitos da física hobbesiana. É importante notar que o que vigorava no campo da ciência no séc. XVII ainda era a tradição aristotélica mantida e interpretada pelos escolásticos. ${ }^{5}$ Hobbes, por sua vez, procura escrever exatamente contra essa tradição, e assim constrói uma explicação científica que vai de encontro aos conceitos de potência e ato vigentes à época. Deste modo, elabora uma explanação que descreve o real, grosso modo, como corpos que agem sob a égide de movimentos e que não se desenvolvem em direção de sua atualização até atingir um fim último e supremo, tal como explicava a escolástica aristotélica. Nesse sentido, afirma Spragens (1973, p.122) ${ }^{6}$ que:

Embora a natureza, na opinião de Hobbes, não se caracterize pela tensão potência e ato como era o cosmos aristotélico, ela possui elementos de tensão. A tensão que Hobbes percebe não é vertical, mas horizontal e ocorre completamente dentro do único plano dos apetites e das aversões...

O modelo hobbesiano deixa evidente, sim, que os corpos atuam de acordo com uma tendência a permanecer como estão, até que "sejam tocados pelo movimento de um outro corpo, o que modifica seu estado" (Hobbes, 1966, p.115). Ou seja, o movimento passa a

5 Ainda que Galileu e Bacon já tivessem produzido obras que questionavam as bases teóricas da visão tradicional aristotélica ensinada nas universidades à época, o aristotelismo ainda era corrente majoritária nos círculos intelectuais. Nesse sentido, é que Hobbes produz sua obra também como um crítico dessa visão tradicional, no entanto, antes mesmo da publicação dos textos hobbesianos, o tradicionalismo aristotélico interpretado pela escolástica, já era posto em xeque pelas penas de outros autores.

6 "Although nature, in Hobbes's view, in not caracterized as the aristotelian cosmos was by the tension of potential and actual, it does have elements of tension within it. The tension which Hobbes perceives is not vertical, but horizontal; it occurs wholly within the single plane of apetites and aversions...". 
se realizar inercialmente e cai por terra a explicação que justifica a relação de causa e efeito permeada por uma causa final. Nesse caminho, novamente com Spragens, percebemos que "A nova face da natureza não é aquela de algo que possui uma tendência inerente para o crescimento e a completude, mas aquela que meramente persiste em seu movimento sem fim" (Spragens, 1973, p.122). ${ }^{7}$ Essa nova explicação científica do mundo visa operar como sustentação para a edificação do conhecimento, de tal forma que, a política e a moral devem ser consideradas após a física, pois:

elas têm suas causas na sensação e na imaginação, que são assuntos de teoria física [...]. Assim, aqueles que estudam filosofia natural fazem-no em vão, a menos que principiem pela geometria, e os autores e polemistas desse assunto que ignoram geometria só fazem perder tempo a seus leitores e ouvintes (Hobbes, 1966, p.73, grifo do autor). ${ }^{8}$

Aqui Hobbes nos oferece mostras claras de que a teoria física ocupa um lugar privilegiado em sua obra, e que, por meio desse modelo explicativo, podemos realizar algumas analogias e observar que a moral em Hobbes, inversamente do que supõe Taylor, possui uma clara conexão com sua ciência mecanicista. A compatibilidade entre esses dois aspectos pode ser evidenciada através de algumas aproximações entre os princípios da física e os da moral.

É um princípio da ciência mecanicista hobbesiana a afirmação de que os corpos tendem a permanecer no estado em que se encontram, ou seja, o corpo "que é movido, sempre estará em movimento" (idem, p.115). O mesmo princípio pode ser usado para explicar o compor-

7 "The new face of nature is not that of something which possesses an inherent tendency toward growth and fulfillment, but rather of something which merely persists in its motion without end"' (Spragens, 1973, p.102).

8 "That they have their causes in sense and imagination, which are the subject of physical contemplation...And, therefore, they that study natural philosophy, study in vain, except they begin at geometry; and such writers or disputers thereof, as are ignorant of geometry, do but make their readers and hearers lose their time". 
tamento humano, isto é, enquanto permanecer vivo o homem tende a procurar todos os meios para se manter nesse estado, e esse é um princípio natural e físico, não moral. O que significa que o desejo que faz que o homem se movimente no sentido de buscar sua própria preservação é o mesmo princípio que move os corpos naturais como um todo, ou seja, o princípio de inércia. Todos os corpos estão submetidos a essa lei.

Outra faceta desse mesmo princípio é aquela que diz que os corpos "só cessam seu movimento se houver outro corpo, além dele, que lhe cause repouso" (idem, p.115). ${ }^{9}$ Aplicada aos homens, essa máxima nos dá a noção de como Hobbes entende a liberdade ${ }^{10}$ humana, ou seja, para o autor a liberdade possui uma definição negativa, e consiste em não haver obstáculos que impeça o livre fluxo de seu movimento atual. Desse modo, podemos inferir que a busca pela preservação do movimento (que é análoga à busca pela preservação da vida) depende das condições de possibilidade de alcançarmos os meios para isso, e na natureza não há nada que o homem esteja desautorizado a fazer quando o assunto é a busca da preservação. A lei que dá a todos o direito a tudo é a mesma que permite o uso indiscriminado de todos os meios para que ela possa se fazer valer. O importante é adquirir os meios para perpetuar o movimento, independentemente de quais sejam.

Essas aproximações entre o modelo conceitual da ciência mecanicista e a explicação do comportamento humano nos parecem oferecer os argumentos para observar criticamente o posicionamento de A.E.Taylor com relação a moral hobbesiana.

Diferentemente da posição adotada por ele, o que procuramos mostrar aqui é que pensar Hobbes como um filósofo que defenda

9 "Will always be moved, except there be some other body besides it, which causeth it to rest" (Hobbes, 1966d, p.115).

10 LIBERDADE, ou INDEPENDÊNCIA significa, em sentido próprio, a ausência de oposição (entendendo por oposição os impedimentos externos do movimento), e não se aplica menos às criaturas irracionais e inanimadas do que às racionais (Hobbes, 2003, p.179). 
uma moral natural capaz de se fazer valer por si só, isto é, capaz de ser medida universal natural que deve ser comumente seguida, pode deixar algumas lacunas explicativas quando tentamos reconstruir seu argumento. Assim, o que dirige a ação moral de um homem não é um princípio universalizante "bom nele mesmo" e de foro interno que independe da existência do Estado soberano como supõe Taylor. Mais de uma vez em sua obra, Hobbes é claro quando diz que "não há nada que o seja simples e absolutamente, nem há nenhuma regra comum do bem e do mal que possa ser extraída da natureza dos próprios objetos" (Hobbes, 2003, p.48) e ainda acrescenta que essa regra só pode existir quando há um representante comum a todos.

Ela (a regra do bem e do mal) só pode ser tirada da pessoa de cada um (quando não há república) ou então (numa república) da pessoa que a representa; ou também de um árbitro ou juiz que pessoas discordantes possam instituir por consentimento, fazendo com que a sentença seja aceita como regra (idem, p.48-9).

Portanto, não se pode dizer com Taylor que "A obrigação moral de obedecer a lei natural antecede a existência do legislador e da sociedade civil" (Taylor, 1965, p.26), ${ }^{11}$ porém talvez seja possível dizer que, de fato, in foro interno, a lei impõe o desejo de seu cumprimento. Contudo, tal afirmação não significa que a lei moral obrigue no sentido de uma moral de caráter universalizante e comum, mas sim como uma necessidade ou desejo natural, mas para efeito de julgamento acerca das ações dos homens a "intenção" ou o desejo, de foro interno, não é uma variável que pode nos oferecer um fundamento sólido.

Hobbes diz que não se pode ter acesso aos desígnios íntimos de cada indivíduo (muito embora seja bom procedimento ler a si mesmo), e exatamente por esse desconhecimento dos desígnios de cada um julgar suas ações tomando por base o que os homens pensam ou maquinam internamente não configura um bom cálculo

11 "The moral obligation to obey the natural law is antecedent to the existence of the legislator and the civil society". 
para construir a paz e a preservação da vida. "Embora por vezes descubramos os desígnios dos homens através de suas ações, tentar fazê-lo sem compará-las com as nossas, distinguindo todas as circunstâncias capazes de alterar o caso, é o mesmo que decifrar sem ter uma chave e deixar-se, o mais das vezes se enganar [...]. " (Hobbes, 2003, p.13).

O que Taylor entende como ação moral justificada por um princípio interno caracteristicamente humano (por isso a tentativa de aproximação com Kant) não é uma lei exclusiva e própria do homem, mas sim um princípio natural que rege todos os corpos naturais, inclusive o homem. ${ }^{12}$ Mas que ainda assim, não dá uma medida para as ações humanas, por isso a necessidade de viabilizar um Estado artificial e soberano que possa legislar e promulgar aquilo que será a regra comum do bem e do mal. $\mathrm{O}$ aparato jurídico que é construído pelo soberano é o único padrão comum que pode oferecer tal regra de modo que antes do Estado civil é abuso de linguagem falar em certo e errado, justo e injusto, bem e mal etc. O julgamento de valor das ações humanas é medido pela regra comum estabelecida pelo soberano, portanto não pode haver, como pretende Taylor, um princípio moral universalizante que anteceda o Estado. No estado de natureza é bom tudo aquilo que contribui para a preservação dos movimentos internos e externos de um indivíduo e que auxilie na preservação de sua vida; mau é aquilo que não contribui para a preservação nem dos movimentos e nem da vida por consequência. Portanto, "enquanto os homens se encontram na condição de simples natureza (que é uma condição de guerra) o apetite pessoal é a medida do bem e do mal" (Hobbes, 2003, p.137, grifo nosso). A medida do bem e do mal, do justo e do injusto, do certo e do errado

12 O desejo natural humano de alcançar os meios necessários para a preservação da vida (manutenção do movimento) é diretamente proporcional à tendência natural que todos os corpos têm em manterem seus movimentos, pois é um princípio natural que os corpos perpetuem em seus movimentos. "[body] is moved, will always be moved, except there be some other body besides it, which causeth it to rest" (Hobbes, 1966d, p.115). 
no estado de natureza conforme diz Hobbes é o apetite humano, e não um princípio moral universal que possa se fazer valer ainda no estado de natureza assim como propõe Taylor. Ainda no Leviatã Hobbes diz: "[...] seja qual for o objeto do apetite ou desejo de qualquer homem, esse objeto é aquele a que cada um chama bom;" (Hobbes, 2003, p.48, grifo nosso). Daí ser possível entender que para Hobbes a filosofia moral (ética) é o estudo das consequências das paixões dos homens. ${ }^{13}$

Desta forma, o valor da lei natural é derivado de um fato natural, isto é, antes de possuir um valor ela é no homem a expressão da lei física que rege o movimento de todos os corpos. Se o homem não pode agir contra si mesmo, ou seja, interromper seu movimento, isso ocorre por ser essa proibição um fato e uma necessidade natural (nenhum corpo pode mover-se a si próprio) e não um juízo moral irredutível. ${ }^{14}$

Da mesma forma, o direito natural que diz que "a natureza deu a cada um o direito a tudo” (Hobbes, 1998, p.32), ou seja, o homem pode fazer uso de tudo aquilo que julgar necessário a sua preservação, não é um fundamento moral universal, mas sim um fato natural de todos os corpos. Portanto, para ter direito aos fins ele deve ter direito aos meios adequados para alcançá-los.

O mesmo ocorre com as leis naturais, elas não obrigam por sua própria força, isto é, elas não impõem a necessidade de cumprimento independente da ação do Estado. Hobbes as menciona como ditames e não como obrigações, e nesse sentido as leis naturais não podem ser tomadas como regras morais, pois não "constituem fins bons em si mesmos e que independem do princípio do benefício próprio" (Frateschi, 2003, p.159-60). E ainda "não obrigam de fato a menos que haja um poder artificialmente constituído capaz de transformar esses ditames naturais em leis de fato" (idem). E, nesse sentido, não parece ser possível sustentar a interpretação que Taylor oferece para explicar o estatuto da moral na filosofia de Hobbes.

13 Cf. Hobbes, 2003, p.74.

14 Cf. Frateschi, 2003a, p.56. 


\section{Warrender}

Outro intérprete que propõe um caminho semelhante ao de Taylor é Howard Warrender, o autor inglês também vê na obra de Hobbes uma base que não é científica e que por isso não principia por métodos geométricos e mecânicos. O que nortearia a ação dos homens seria a necessária ligação entre o direito natural e o direito moral e divino. Desse modo, o que inclinaria o homem a agir de modo a seguir um princípio moral universal seria a adesão desse agir moral aos ditames da lei divina e cristã, e essa abordagem abre espaço para que possa se pensar que a obrigação moral é baseada em um "postulado de que a obrigação do cidadão de obedecer à lei civil é um tipo de obrigação que é essencialmente independente do fiat da soberania civil" (Warrender, 2000, p.7).

Em sua exposição, Warrender não chega a negar que exista um tipo de obrigação que seja derivada dos princípios da filosofia natural que ele nomeia de obrigação física, porém essa obrigação desempenha um papel secundário na filosofia hobbesiana, pois seria raramente mencionada pelo autor no decorrer da obra. E ainda no sentido de mostrar que a obrigação física não seria capaz de oferecer um modelo explicativo para a concepção de moral presente na obra de Hobbes, Warrender diz que essa obrigação envolve um tipo de obediência involuntária que concerne apenas a objetos inanimados, como por exemplo, quando um "corpo obedece uma lei física ao cair ou quando ele é empurrado por outro corpo" (idem, p.9). Esse seria apenas um exemplo dado por Hobbes de um dos tipos de obrigação, porém esse exemplo seria "útil apenas para enfatizar o caráter invariável e involuntário dessa ação, que é de natureza física" (idem, p.4).

A distinção entre dois tipos de obrigação, a moral e a física, leva o autor a concluir que, se a obrigação sustentada por Hobbes for do tipo físico ela seria uma teoria descritiva, portanto de caráter prudencial, de como o homem age e não uma teoria prescritiva de como o homem deve agir. E se for assim, diz Warrender: 
Tal interpretação, entretanto, recusa todo o uso normativo do termo obrigação, e nega a existência no trabalho de Hobbes de qualquer teoria da obrigação que seja corretamente aplicável às leis com um caráter moral ou legal (idem, p.4). ${ }^{15}$

Percebe-se aqui que o autor aceita a existência de uma interpretação da obra de Hobbes que não recusa a presença da ciência natural na análise da moral. Contudo, ele precisa recusar essa interpretação pelo fato de que, para Warrender, a lei moral em Hobbes possui um caráter moral e prescritivo universal, ou seja, ela é capaz de oferecer uma medida comum natural que possibilite o acordo entre os homens antes mesmo da construção do Estado civil soberano. No entanto, para que sua interpretação possa se manter sólida é necessário sustentar que existe um tipo de obrigação moral universal que está presente tanto no homem em estado de simples natureza, como no homem já dentro do Estado civil. E isso exige que Warrender lance mão de passagens na obra de Hobbes que parecem corroborar com a posição de que há uma obrigação que pode ser chamada de moral e que tenha um conteúdo comum e universalizante já no homem natural, e que essa obrigação estaria fundada em duas premissas básicas:

(1) O homem deve obedecer à lei natural porque a obediência é um meio para salvação que é seu maior interesse; ou inversamente, negligenciar essas leis leva à punição divina, que representa seu maior mal (2) A lei natural é a vontade de Deus e deve ser obedecida por essa razão (idem, p.279). ${ }^{16}$

15 "Such an interpretation, however, rules out any normative use of the term, obligation, and denies the existence in Hobbe's work of any theory of obligation which is properly applicable to laws of a moral or legal character" (Warrender, 2000, p.4).

16 "(1) Men ought to obey natural law because obedience is a means to salvation, which is their highest interest; or contrariwise, neglect of these laws leads to divine punishment, which represents their greatest evil (2) Natural law is the will of God, and ought to be obeyed for that reason" (idem, p.279). 
O que pode sustentar essa interpretação são as várias passagens presentes na obra de Hobbes em que ele aproxima a lei moral e a lei natural como sendo preceitos divinos. Hobbes chega mesmo a derivar uma a uma todas as leis de natureza de passagens presentes nas sagradas escrituras, dizendo que "a mesma lei que é natural e moral também é merecidamente chamada de divina" e ainda, "o mesmo que mostramos pelo raciocínio, quanto à lei de natureza, [pode ser alcançado também] pelo recurso à Sagrada Escritura" (Hobbes, 1998, p.75, grifo do autor). Desta forma, seria amparada nas leis de natureza, que são leis morais e divinas, que se fundaria a obrigação moral do homem hobbesiano. E por serem essas leis divinas e naturais, elas estariam presentes antes mesmo da construção do Estado soberano, ou seja, estariam fundadas no poder irresistível de Deus. De acordo com Warrender, portanto, seria nesse sentido que devemos entender a passagem do texto de Hobbes (2003, p.301-2, grifo nosso) que diz que:

O direito de natureza, pelo qual Deus reina sobre os homens, e pune aqueles que violam as suas leis, deve ser derivado, não do fato de os ter criado, como se exigisse obediência por gratidão pelos seus benefícios, mas sim por seu poder irresistível [...]. Para aqueles portanto cujo poder é irresistível, o domínio de todos os homens é obtido naturalmente por sua excelência de poder; e por consequência é por aquele poder que o reino sobre os homens, e o direito de afligir os homens a seu bel prazer, pertence naturalmente a Deus Todo-poderoso, não como criador e concessor de graças, mas como onipotente.

Note-se, porém, que na passagem citada acima Hobbes é cuidadoso ao distinguir que o poder de Deus sobre os homens não se ampara em um direito de mando ou autoridade que está fundado na graça divina ou no fato de ser Deus o criador do tudo que há sobre a terra. Esse direito de mando de Deus sobre os homens está fundado no poder irresistível, isto é, na excelência de poder que há em Deus. Contudo, essa excelência de poder só obriga quem a reconhece como um poder divino, aqueles que não creem nesse poder não são 
obrigados moralmente a seguir os desígnios por ele ditados. Mesmo que Deus seja o rei de toda a Terra, aqueles que não o veem como tal não possuem a necessidade de obediência, pois Ele só é rei do povo que pactuar e reconhecer tal reinado. Se não há o reconhecimento, não há obrigação de obediência. Hobbes é claro ao diferenciar esses dois domínios do poder divino, pois "Deus é rei de toda a Terra por seu poder, mas do seu povo escolhido é rei em virtude de um pacto" (idem, p.102).

Warrender, contudo, segue noutra direção ao considerar tal argumento, ou seja, ele assume que é o poder de Deus que funda a moralidade da obrigação humana. Porém, ao levar adiante tal interpretação, ele precisa resolver a questão de como se colocaria os ateus e os insanos dentro desse modelo de moralidade, já que eles podem não reconhecer Deus como criador e Todo-poderoso. A sanidade e a maturidade são para Warrender condições prévias para a maioria dos deveres éticos, e em Hobbes não seria diferente, pois "um indivíduo não pode ser obrigado se ele for louco (insane) ou se for uma criança" (Warrender, 2000, p.15). Aqui, caberia a seguinte questão: de acordo com Hobbes, quem decide quem é louco ou não no estado de simples natureza e no Estado civil? ${ }^{17}$

Para resolver essa questão e ao mesmo tempo sustentar sua posição, o autor lança mão do que ele chama de condições de validação da obrigação moral, essas condições apresentariam as circunstâncias

17 Como vimos, no estado de simples natureza não há nenhuma medida comum e universal, pois cada indivíduo tem o direito de buscar todos os meios necessários a sua própria sobrevivência, nesse sentido, só haverá medida comum que obriga a todos quando houver o corpo político. Hobbes oferece várias mostras desse seu posicionamento, entre eles pode-se destacar o seguinte: "O roubo, o assassínio, e todas as injúrias são proibidos pela lei de natureza; mas o que há de se chamar roubo, assassínio ou injúria a um cidadão não se determinará pela lei natural, mas pela lei civil" (Hobbes, 1998, p.112). Ao seguir a lógica dessa reflexão hobbesiana, é possível entender que a distinção feita por Warrender no sentido de mostrar que loucos e ateus não estão sob o imperativo da obrigação moral, que para o autor é natural e divina, parece carecer de sustentação. Pois a loucura e a sanidade não podem ser discernidas no estado de simples natureza, isto é, pela lei natural, mas apenas pela lei civil que é constituída após o pacto. 
que devem ser satisfeitas, ou os fatores que devem estar presentes, antes que o indivíduo possa ser obrigado. Assim, se a "condição de obrigação é a vontade de Deus, e se ' $x$ ' é obrigatório, então ' $x$ ' é obrigatório porque é a vontade de Deus" (idem, p.14). De acordo com essa interpretação, para entender qual é a origem da moral é preciso perguntar o porquê a lei obriga, de tal forma que, a "última resposta a essa pergunta deverá ser considerada o fundamento da moral" (idem, p.14-5).

Contudo, como foi mostrado acima na passagem do Leviatã, a obediência aos ditames de Deus está fundada no poder irresistível que Lhe é próprio. Porém, os insanos e os ateus podem não crer que o poder de Deus seja irresistível, e podem nem mesmo acreditar que ele exista. Isso no entanto, não significa que o ateu será perdoado por suas faltas, ele será punido pela lei de Deus da mesma forma que o crente, contudo, ele não será punido como um "sujeito que desobedece ou que falha na observância da lei divina, e sim como um inimigo que não aceita tais leis” (idem, p.285).

Assim, é possível entender que a visão do intérprete nos leva à seguinte conclusão: se não há o reconhecimento do poder divino, então não existe também a obrigação moral de cumprir os ditames (leis de natureza, que é semelhante à lei divina) estabelecidos por esse poder. Dessa forma, o ateu não pode ser considerado injusto por desobedecer à lei, mas o crente pode assim ser considerado.

Ora, essa conclusão tirada da análise do argumento do próprio autor é exatamente oposta a sua proposta inicial que era de sustentar que o poder divino funda a obrigação moral universal, independentemente se esse poder é ou não reconhecido pelos homens. Portanto, diante desse diagnóstico, continua o problema de como pode ser sustentado o argumento de que as leis naturais, como leis divinas, é que dão o conteúdo moral para a ação humana. Na interpretação proposta por Warrender, parece que permanece o problema com relação àqueles que não reconhecem o poder de Deus como irresistível e supremo, pois esses estariam isentos da obrigação moral, dita natural e divina. $\mathrm{O}$ fato de o autor supor uma distinção entre ação descritiva física (prudencial) e ação prescritiva moral (divina), 
não parece resolver a questão em seu favor, mas sim oferecer mais argumentos para a crítica de sua abordagem.

Quando Warrender diz que a ação de um indivíduo ateu é baseada no cálculo prudencial e por isso ele não poderia, no estado de simples natureza, ser chamado de injusto, mas sim imprudente, ele parece mostrar nesse momento que a justiça e a injustiça não é algo universalmente presente em todos os indivíduos no estado de natureza. Pois os ateus (assim como os loucos e as crianças) podem não reconhecer o poder de Deus e não agir moralmente.

Embora o poder de Deus o faça governar os homens de tal modo que ninguém possa cometer nada se Deus assim não quiser, isto porém, para falar de maneira própria e acurada, não é exatamente o mesmo que reinar. Pois afirma-se que reina quem governa, não por meio de atos, mas pela fala, isto é, usando de preceitos e ameaças. E por isso, no reino de Deus, não consideramos como seus súditos os corpos inanimados ou irracionais, embora estejam subordinados ao poder divino $[\ldots]$ nem tampouco os ateus, porque não acreditam que Deus exista (Hobbes, 1998, p.240, grifo nosso).

Portanto, parece ser claro que o poder de Deus por si só não é capaz de oferecer a universalidade moral necessária para obrigar a ação comum dos indivíduos no estado de simples natureza, pois a lei divina obriga apenas aqueles que a reconhecem através da razão, ou seja, in foro interno, nos termos do próprio Hobbes. Nesse sentido, pode-se pensar o seguinte: a lei fundamental da natureza que é um ditame da razão, e também uma lei moral e divina, afirma que os homens devem "procurar a paz, quando possa ser encontrada; e se não for possível tê-la, que nos equipemos com os recursos da guerra" (idem, p.38). Ora, se a lei de natureza diz que tanto a guerra quanto a paz são legítimas e, portanto, moralmente justificadas no estado de simples natureza, então é precipitado dizer que existe alguma lei ou regra que justifique naturalmente algum tipo de dever moral universal. A guerra e a paz são legítimas no estado de natureza pelo fato de que não há medida do certo e do errado nesse estado e essa 
afirmação pode ser melhor entendida por uma explicação amparada nos conceitos da ciência mecanicista.

Como vimos no capítulo 1, Hobbes entende que a realidade é composta por corpos que tendem sempre a se manter em movimento, assim é natural que em algum momento eles se choquem. É interessante notar que, nessa explicação, física não há espaço para "intenções" como uma característica propriamente humana tomada no sentido moral universal, ou seja, os corpos (os homens em específico) não se chocam entre si porque são maus e procuram a guerra indistintamente em todos os casos, mas sim porque a busca da preservação do movimento vital é antes de tudo uma busca individual, ou seja, pode ser tomada como a busca pelo próprio benefício. Essa busca projetada no futuro pode fazer com que os homens deliberem pelo uso e fruição dos mesmos objetos ao mesmo tempo, ${ }^{18}$ o que leva à disputa e à guerra, portanto essa projeção de futuro é causa de tensão e conflito no presente. Por ser o homem um corpo que faz parte de uma realidade que é submetida a leis físicas, ele sempre está sujeito a colocar-se como impedimento ao livre movimento dos outros homens. Essa lógica física é que permite com que Hobbes possa dizer que não há medida do justo e do injusto no estado de natureza e que só o poder soberano é que pode fundar essa medida pois "onde não há poder comum não há lei, e onde não há lei não há injustiça” (Hobbes, 2003, p.111).

Na guerra, a força e a fraude são as duas virtudes cardeais. A justiça e a injustiça não fazem parte das faculdades do corpo ou do espírito. Se assim fosse, poderiam existir num homem que estivesse sozinho no mundo, do mesmo modo que os seus sentidos e paixões. [A justiça e a injustiça] são qualidades que pertencem aos homens em sociedade, não na solidão (idem).

18 “...a razão mais frequente porque os homens desejam ferir-se uns aos outros vem do fato de que muitos, ao mesmo tempo, têm um apetite pela mesma coisa; que, contudo, com muita frequência eles não podem nem desfrutar em comum, nem dividir..." (Hobbes, 1998, p.30). 
Um outro argumento levantado por Warrender para sustentar a lei divina como base para a obrigação moral é que não há como fazer contrato e estabelecer o Estado se não houver uma base moral que seja anterior ao próprio contrato, pois "sem isso, o homem nunca poderia fazer a transição do estado de natureza para o Estado civil" (Warrender, 2000, p.47). Segundo o autor, existem contratos no estado de simples natureza, e uma das razões da existência das regras morais seria a necessidade de oferecer uma garantia (medida universal) que pudesse sustentar o cumprimento desses contratos. E essa garantia é dada pela lei natural que é moral e divina, pois ela constitui uma "obrigação para o homem tanto no estado natural quanto no estado civil” (idem, p.52).

Contudo, esse problema levantado por Warrender pode ser dirimido quando se entende que na constituição do contrato que estabelece o Estado soberano, todos os homens transferem seu direito pessoal a um terceiro, porém, esse indivíduo para quem o direito é transferido não transfere seu próprio direito. Nesse sentido, o soberano permanece como se estivesse no estado de simples natureza, isto é, ele é o único dentro do Estado que permanece com direito a todas as coisas e a Soberania do Estado está fundada exatamente nessa condição.

É evidente que quem é tornado soberano não faz antecipadamente nenhum pacto com seus súditos, pois teria ou que o celebrar com toda a multidão, na qualidade de parte do pacto, ou de celebrar diversos pactos, um com cada um deles. (Hobbes, 2003, p.150)

Desse modo, percebe-se que o soberano não é obrigado pelas leis civis, pois ele não é parte integrante do pacto, ou seja, ele não transfere seus direitos e por isso não tem deveres perante os súditos. Considerar o soberano como parte do pacto é na verdade, segundo Hobbes, "incompatível com a natureza da república" (idem, p.275).

O soberano não está sujeito àquelas leis que ele próprio, ou melhor, que a república fez. Pois, estar sujeito a leis é estar sujeito à 
república, isto é, ao soberano representante, ou seja, a si próprio, o que não é sujeição, mas liberdade em relação às leis. Este erro, porque coloca as leis acima do soberano, coloca também um juiz acima dele, com poder para castigá-lo, o que é fazer um novo soberano [e isso contribui] para confusão e dissolução da república (idem, p.275).

Exatamente por esse aspecto é possível fundar o Estado sem que seja necessário supor a existência de uma base moral que preexista já no estado de simples natureza. O soberano, mesmo no Estado civil, é o único que ainda mantém seu direito natural sem transferi-lo. A esse respeito Yara Frateschi afirma:

Quando Hobbes diz que as leis de natureza são leis morais, não o faz no sentido que Taylor e Warrender lhe imputam, tampouco no sentido que a tradição lhe imputa. Em primeiro lugar porque não se trata de regras morais que constituem fins bons em si mesmos e que independem do princípio do benefício próprio, e em segundo lugar porque elas não obrigam de fato a menos que haja um poder artificialmente constituído capaz de transformar esses ditames naturais em leis de fato. É a força do Estado, e não a razão, que transforma as leis naturais em leis em sentido estrito. (Frateschi, 2003a, p.160)

Tal argumento se justifica na medida em que é necessário mostrar que não há acordo possível no estado de simples natureza, pois a consideração mecanicista da moral natural não permite que exista uma medida que seja universal nela mesma, isto é, que possa ser princípio normativo para um acordo entre os homens. Isso significa que não há conteúdo normativo universal que seja princípio que ampare um acordo no estado de simples natureza. Ainda que a referência a princípios da natureza permaneça na obra de Hobbes, ela não é mais padrão universal já que fica a cargo de cada indivíduo seu julgamento e seu uso. Por isso, ao considerar essa natureza a partir da ciência mecanicista, Carlos Alberto Ribeiro de Moura diz: "ela torna-se uma referência vazia, já que a natureza não desempenha mais o papel de fornecer a medida [comum e universal] do direito" 
(Ribeiro de Moura, 2002, p.55). Não há prescrição no estado de simples natureza, pois tudo é decidido de modo individual, o que leva necessariamente ao conflito generalizado.

$\mathrm{Na}$ visão de Warrender, o fundamental na relação entre lei natural e obrigação política fica restrito a considerações de ordem divinas e Hobbes torna-se essencialmente um fideísta. Isso gera uma inconsistência no argumento que é apontada por Spragens, pois parece que Hobbes "acreditou na impossibilidade de proposições teológico-racionais mas todavia, fundou uma teoria política sobre a vontade divina" o que faz com que "todas as proposições psicológicas tornem-se interpretações logicamente desnecessárias" (Spragens, 1973, p.119). E, finalmente, diz ainda:

Essa interpretação traduz como puramente acidental o que Hobbes certamente teria considerado sua realização distintiva, ou seja, a afirmação de que o dever não apenas não é incompatível com o autointeresse, mas que se segue dele (idem, p.120). ${ }^{19}$

\section{Leo Strauss}

O alemão Leo Strauss, ainda que em um caminho distinto de Warrender e Taylor, também constrói uma argumentação acerca da obra de Hobbes de tal forma que ela pode ser pensada como uma obra política e moral que pode perfeitamente ser compreendida sem que seja necessário recorrer aos conceitos próprios da ciência mecanicista moderna. Strauss afirma:

A filosofia política é independente da ciência natural porque seus princípios não são emprestados da ciência natural, não são cer-

19 "This interpretation renders purely accidental what Hobbes would certainly have considered his distinctive achievement, namely, the demonstration that duty is not only not incompatible with self-interest, but follows from it" (Spragens, 1973, p.120). 
tamente emprestados de nenhuma ciência, mas são fornecidos pela experiência que cada um tem de si mesmo ou, mais precisamente, pelos esforços do autoconhecimento e do autoexame de cada um. (Strauss, 1963, p.7)

Strauss pretende mostrar essa independência da filosofia política em relação à ciência moderna e também em relação à tradição medieval, para isso ele segue dois caminhos: de um lado, defende que a concepção de natureza humana presente na obra de Hobbes já estava fundamentalmente estabelecida antes mesmo que o autor tomasse contato com a ciência de matriz tipicamente moderna, e para isso Strauss se atém aos escritos que antecedem os Elementos de Lei Natural e Política (1640). De outro lado, ele indica que Hobbes no início de sua produção filosófica possui alguma ligação com os conceitos da tradição, porém com o desenrolar de sua produção acaba por se afastar, e até mesmo se opor a eles, e isso fica claro para Strauss quando se investigam os escritos pós Elementos de Lei.

Uma distinção marcante entre a concepção de lei natural tradicional e a lei natural moderna seria o fato de que na tradição medieval, a lei natural funcionava como regra e medida independente da vontade humana, já na concepção moderna a lei natural tende a ser principalmente e primeiramente uma série de direitos de reivindicação subjetivo que tem origem na vontade humana. E, nesse sentido, Strauss diz que a intenção de seu livro é "entender Hobbes como fundador da filosofia política moderna e compará-lo com Platão e Aristóteles que são os fundadores da filosofia política tradicional" (idem, p.viii).

A passagem na obra de Hobbes que serve de base para que Strauss possa sustentar seu argumento, que procura mostrar que não há necessidade de recorrer aos conceitos da ciência moderna para se entender a política e, consequentemente, a moral que lhe corresponde, é aquela presente no Leviatã segundo a qual os homens não comprazem em contemplar o próprio poder em atos de conquista sem que aumente esse poder por meio de invasões. Por isso, deve-se conceder como natural o domínio de um homem sobre o outro como algo necessário à conservação de cada um no estado de natureza (cf. 
Hobbes, 2003, p.108). Strauss, ao analisar essa passagem, diz que o "esforço de poder é racional nele mesmo e se for guiado por esse poder o homem se contentará com um poder moderado”, contudo, continua Strauss, "existe um poder infinito, irracional e inadmissível que leva o homem a não se contentar com o poder adquirido" (Strauss, 1963, p.11). Esse poder é o apetite natural humano que é baseado na consideração do próprio poder do homem e é o que pode se chamar de vaidade, portanto "a origem do apetite natural humano não é a percepção (como consideram aqueles que entendem que a ciência moderna possui relação com a moral e a filosofia política), mas sim a vaidade" (idem). Desta forma, a vaidade enquanto paixão (apetite) natural seria a responsável por dirigir o homem para uma busca infinita por poder que culmina necessariamente na guerra. Não haveria necessidade racional, segundo Strauss, de se buscar incessantemente o poder, a razão dita que o homem deveria se contentar com o poder já adquirido, contudo, o apetite humano "irracional e inadmissível”, guiado pela vaidade, sempre induz o homem à necessidade de mais e mais poder.

Todas as paixões e todas as formas de loucura são modificações do conceito ou do sentido de inferioridade, ou em princípio, do empenho de precedência e de reconhecimento dessa precedência. De acordo com a visão de Hobbes, o motivo deste empenho é o desejo do homem de fazer o exame do seu próprio prazer, considerando sua própria superioridade, e sua própria superioridade reconhecida, é vaidade. (idem, p.12) $)^{20}$

Strauss ainda sustenta que a análise mais aproximada das três versões dos textos políticos, Elements of Law, De Cive e Leviatã, mostra que, se Hobbes tivesse dado continuidade ao argumento da

20 "All passions and all forms of madness are modifications of conceit or of a sense of inferiority, or in principle, of the striving after precedence and recognition of that precedence. According to Hobbes's view, the motive of this striving is man's wish to take pleasure in himself by considering his own superiority, his own recognized superiority, is vanity" (Strauss, 1963, p.12). 
necessidade natural da guerra de todos contra todos, ele teria necessariamente "derivado esse estado da consideração do apetite natural humano, mais propriamente, da vaidade” (idem).

Da mesma forma, o medo também ocupa um papel relevante no argumento de Strauss pois, ao lado da vaidade, formaria a antítese de onde se iniciaria a filosofia política. O medo da morte violenta seria a paixão que levaria o homem ao uso da razão, e a vaidade por sua vez, seria a raiz do apetite natural. Contudo, Strauss considera que Hobbes não pode considerar o medo como raiz da moralidade pelo fato de que ele reduz o apetite natural humano à vaidade.

Pois, se o apetite natural humano é a vaidade, isso significa que o homem se empenha por natureza em exceder todos os seus semelhantes e em ter sua superioridade reconhecida por todos os outros, de modo que tenha prazer em sua própria consideração; e que deseja naturalmente que o mundo inteiro o tema e o obedeça. (idem, p.18) ) $^{21}$

Contudo, esse caminho adotado por Strauss, que procura negar a ciência natural como algo presente na formulação da moral e da política de Hobbes em favor da consideração da experiência de um apetite natural específico, a saber, a vaidade, pode ser questionado em alguns pontos. Vejamos.

Parece ser possível entender de outro ângulo a análise de Strauss segundo a qual a busca incessante de poder está amparada em um apetite natural, especificamente na vaidade. Quando Hobbes diz que o Homem possui um "perpétuo e irrequieto desejo de poder e mais poder, que cessa apenas com a morte” (Hobbes, 2003, p.85), parece-nos que não se pode, com Strauss, derivar tal desejo de uma paixão, mas sim da consideração dos princípios mecânicos aos quais os homens estão submetidos. Pois é um princípio natural que todo

21 For if man's natural appetite is vanity, this means that man by nature strives to surpass all his fellows and to have his superiority recognized by all others, in order that he may take pleasure in himself; that he naturally wishes the whole world to fear and obey him" (Strauss, 1963, p.18). 
o corpo tende a persistir em seu movimento, no caso específico do homem isso significa que todo homem tende a preservar sua vida (que é movimento). Para se preservar a vida, é preciso buscar todos os meios necessários e a busca desses meios nada mais é que a busca por poder. No entanto, o poder acumulado hoje pode não ser suficiente para se preservar a vida de um ataque futuro, assim, a busca por poder ${ }^{22}$ jamais deve cessar, pois ele é a garantia atual de que se está suficientemente munido de condições capazes de garantir nossa própria segurança. Assim, diferentemente de Strauss, é possível entender que a busca incessante por poder é condição natural (e racional) de preservação da vida no estado de simples natureza, desde que a consideremos não como um apetite natural (vaidade), mas sim como resultado de um princípio científico e mecânico que atua em todos os corpos naturais, inclusive no homem.

Parece ser claro que Hobbes relaciona as formulações e o vocabulário mecânico da ciência moderna para explicar tanto os corpos naturais quanto os corpos artificiais, nesse sentido vale a pena citar um trecho, ainda que extenso, porém esclarecedor, que se refere às aproximações feitas por Hobbes entre o corpo humano e um corpo artificial (Estado).

Pois, considerando que a vida não passa de um movimento dos membros cujo início ocorre em alguma parte principal interna, por que não poderíamos dizer que todos os autômatos (máquinas que se movem por meio de molas e rodas, tal como um relógio) possuem uma vida artificial? Pois o que é o coração, senão uma mola; e os nervos, senão outras tantas cordas; e as juntas, senão outras tantas rodas, imprimindo movimento ao corpo inteiro, tal como foi projetado pelo artífice? E a arte vai mais longe ainda, imitando aquela criatura racional, a mais excelente obra da natureza, o homem. Porque pela arte é criado aquele grande Leviatã a que se chama República, ou

22 "O poder de um homem (universalmente considerado) consiste nos meios de que presentemente dispõe para obter qualquer manifesto bem futuro" (Hobbes, 2003, p.75). 
Estado (civitas), que não é senão um homem artificial, embora de maior estatura e força do que o homem natural, para cuja proteção e defesa ele foi projetado. E no qual a soberania é uma alma artificial, pois dá vida e movimento ao corpo inteiro, os magistrados e outros funcionários judiciais ou executivos, juntas artificiais, a recompensa e o castigo [...] são os nervos que fazem o mesmo no corpo natural. [...] E que por último, os pactos e convenções mediante os quais as partes deste corpo político foram criadas, reunidas e unificadas assemelham-se àquele Fiat, ao Façamos o homem proferido por Deus na criação. (idem, p.12)

Note-se que as analogias apresentadas acima entre o Estado enquanto corpo político e o homem enquanto corpo natural possibilitam entender que Hobbes procura estabelecer uma relação entre os corpos artificiais e os corpos naturais. Essa relação não precisa necessariamente ser uma dedução estrita dos princípios advindos da ciência natural moderna, ela pode ao menos funcionar como um padrão ou chave explicativa, por analogia ou como um paralelo entre os dois tipos de corpos existentes, a saber, os naturais e os artificiais. E nesse sentido, a filosofia moral (que é o estudo das consequências das paixões da mente) e a política (que é o estudo dos corpos artificiais) se desenvolveriam em um campo permeado pela ciência moderna. É nessa direção que, diferentemente de Strauss, Thomas Spragens (1973, p.175) defende a relação entre filosofia moral, política e ciência, pois:

É possível que a filosofia da natureza exerça impacto considerável sobre a filosofia das coisas humanas, mesmo que essa filosofia da natureza não seja antropomórfica [...] mesmo uma filosofia não antropomórfica pode trabalhar por analogia para formar, sugerir, limitar, consolidar, expandir, substancializar, estabilizar, reforçar formalmente modelos paralelos da vida política.

O que Spragens mostra é que o papel desempenhado pela filosofia natural ou ciência moderna na obra de Hobbes pode não ser uma 
relação de dedução estrita, ou seja, não é preciso considerar que a moral e a política se seguem dedutivamente da consideração da ciência. Essa relação pode se dar por analogia, isto é, a ciência pode atuar como um padrão ou chave explicativa que ajuda na compreensão da complexidade do funcionamento do aparato político. Por recusar a necessidade de qualquer relação entre ciência natural e a filosofia política e moral, Strauss interpreta a necessidade do homem de obter cada vez mais e mais poder ${ }^{23}$ como algo que é originário da vaidade humana.

Porém, é notável que Hobbes circunscreve tal desejo de poder no âmbito de uma necessidade natural, ou melhor, de um fato natural, isso implica dizer que não há juízo de valor universalizante por detrás dessa consideração acerca do desejo de poder propriamente humano. O que há é uma consideração de caráter natural de uma lei que rege todos os corpos, inclusive o corpo humano, de tal modo que a busca incessante de poder é necessária, porque sem ela não é possível garantir a própria conservação do homem. Aquele poder que hoje é capaz de manter e garantir a paz pode, amanhã ou depois, ser suplantado por um outro, seja por meio de secreta maquinação, seja por meio da união com outros indivíduos.

Desse modo, a busca por poder e mais poder é algo natural, racional e necessário a todo homem no estado de simples natureza, ou seja, a lei que rege a natureza é a mesma que rege o homem, por isso, ao contrário do que propõe Strauss, ela não pode ser imputada a uma paixão humana específica como a vaidade.

A proposta de Strauss que assevera a primazia da experiência da vaidade como apetite natural (paixão), que possui uma conotação moral universalizante e que serve de ponto de partida natural

23 "Assinalo assim, em primeiro lugar, como tendência geral de todos os homens, um perpétuo e irrequieto desejo de poder e mais poder, que cessa apenas com a morte. E a causa disso nem sempre é que se espere um prazer mais intenso do que aquele que já se alcançou, ou que cada um não possa contentar-se com um poder moderado, mas o fato de não poder garantir o poder e os meios para viver bem que atualmente se possuem sem adquirir mais ainda" (Hobbes, 2003, p.85, grifo nosso). 
para se entender a política e a moral hobbesiana independente das considerações acerca da ciência de base mecanicista, distancia-se da proposta que se pretende sustentar nesse trabalho, qual seja, a de que as paixões humanas são reações provocadas pela ação do movimento de corpos externos e que por isso não oferecem universalidade moral capaz de atuar como medida comum do certo e do errado, do justo e do injusto, do bem e do mal no estado de simples natureza.

Do ponto de vista político, o posicionamento teórico de Strauss parece nos levar a consideração de que os principais traços passionais do homem hobbesiano como a competição, a busca por glória, a vaidade são antes de tudo postulados morais fundamentais. O que só é possível ser sustentado por ele graças a sua não consideração da ciência natural. Muito embora Hobbes afirme que a competição, a desconfiança, a glória, a honra, a vaidade etc. são características naturais e causas da discórdia (guerra) entre os homens, acusar o homem de possuí-las é atribuir considerações morais de caráter universal a um fato que é derivado da aplicação no homem dos princípios da filosofia da natureza ou ciência natural macanicista. O homem hobbesiano compete por glória não porque essas paixões são ditames morais fundamentais, mas sim porque a vaidade e a glória são sinais de poder. A única forma que os homens possuem de manter sua vida no estado de natureza é adquirir poder e mais poder e essa busca também não é sinal de vaidade, mas sim uma necessidade sem a qual o homem não pode garantir sua própria vida. Nesse sentido, a busca incessante de poder que Strauss entende como um traço moralizante que leva o homem à guerra e a tensão constante no estado de simples natureza, deve ser considerado à luz da ciência natural como o resultado necessário da aplicação no homem dos princípios físicos universais que regem todos os corpos naturais. Spragens mais uma vez nos ajuda a compreender tal consideração quando afirma que:

Somente os loucos moralizam no vácuo; e uma vez que a natureza instilou em todo homem um dado desejo inevitável, não está em meu poder declarar esse desejo ilegítimo [...] Autoridade confere direito, e a natureza é a autora da direção inata do homem para a autopreser- 
vação [...] começar a teoria política nesse ponto fixo é apenas um ato de consentir no que a natureza nos deu; isso é um ato de sanidade e de ciência, não a promulgação de um ditado moral. (idem, p.180) ${ }^{24}$

É no sentido de sustentar tal proposta que a partir de agora se passará à análise das paixões humanas, de tal modo a dar mais ênfase a duas em especial: o medo e a esperança, que são as paixões que, ao lado da razão, fazem os homens tenderem para a paz.

24 "Only madmen moralize in a vacuum, and once nature instilled in all men a given inevitable desire, it was not in may power to declare the desire illegitimate [...] Autority confers rights, and nature is the author of man's innate drive for self-preservation [...] and to begin political theory at his fixed point is only an act of acquiescence in what nature has given us; it is an act of sanity and science, not the promulgation of a moral dictate" (Spragens, 1973, p.179-80). 



\section{3 \\ As PAIXÕES HUMANAS}

\section{As paixões, o conatus e a imaginação}

Até aqui procuramos abordar a obra hobbesiana de modo a apontar as possibilidades de estabelecer aproximações entre a filosofia natural e a filosofia política, os ganhos que se alcança com essa interpretação e as lacunas que surgem das abordagens que não seguem esse caminho. Nesse sentido, procuramos destacar o privilégio que o autor parece atribuir aos conceitos próprios da ciência de matriz mecânica como norteadores de sua obra. A partir de agora, o intuito é mostrar como essa cosmologia fisicalista atua no âmbito das paixões humanas retirando toda possibilidade de construir, a partir delas, um consenso natural que seja capaz de oferecer as bases que possibilitarão a construção da paz.

Para sustentar que as paixões humanas não possuem naturalmente um conteúdo moral que seja universalmente válido e capaz de atuar como medida comum no estado de simples natureza (inversamente do que supõe Strauss com relação à vaidade) é preciso entendê-las como reação à ação dos movimentos dos objetos externos que afetam o corpo agente da ação. Contudo, essa reação não é relativa a um único movimento causado por um único objeto, ela é sim uma reação à ação dos movimentos de vários objetos que, por sua vez, são 
ligados à experiência acumulada na imaginação, ou seja, como afirma Limongi (1999, p.32), as paixões são:

produto de uma série de conatus, que enquanto se somam e se subtraem entre si, sem ainda produzirem um efeito visível, funcionam como uma espécie de escala, em que o movimento recebido se reequaciona para produzir um novo movimento, que é a ação ou movimento voluntário.

Nesse sentido, as paixões não são simples reações diretas provocadas pela ação do movimento dos objetos externos, mas sim reações indiretas que resultam da adequação e ponderação de vários movimentos que antecedem a ação, aliados à experiência acumulada contida na imaginação. $\mathrm{O}$ homem e as paixões humanas que lhe correspondem em não são apenas efeito da ação direta de objetos externos, a experiência acumulada contida na imaginação ${ }^{1}$ também possui um papel importante no processo de formação das paixões, pois a imaginação é a origem interna dos movimentos voluntários chamados paixões. Contudo, como é possível tornar compatível tal consideração que entende as paixões humanas como reações indiretas com uma outra afirmação hobbesiana que diz que a imaginação é a origem interna dos movimentos voluntários (paixões), ou seja, como pode ser possível conceber um início interno para os movimentos voluntários (paixões) e ao mesmo tempo sustentar que tais movimentos são reações à ação dos movimentos dos objetos externos?

1 Para Hobbes, a imaginação é a experiência produzida pela ação dos movimentos dos objetos externos e que fica retida na mente. Essa experiência também é movimento e pode ser entendida como aquilo que vemos ocorrer na água quando "cessado o vento, as ondas continuam a rolar durante muito tempo ainda [e o mesmo] acontece também no movimento produzido nas partes internas do homem, quando ele vê, sonha etc., pois após a desaparição do objeto, ou quando os olhos estão fechados, conservamos ainda a imagem da coisa vista, embora mais obscura do que quando a vemos...A imaginação nada mais é portanto que uma sensação em declínio" (Hobbes, 2003, p.18, grifo nosso). 
Bem, para compreender essa aparente aporia é preciso começar por esclarecer qual o papel que a sensação desempenha dentro dessa explicação acerca do processo de formação das paixões humanas, "pois não há concepção no espírito do homem que primeiro não tenha sido originada, total ou parcialmente, nos órgãos dos sentidos" (Hobbes, 2003, p.15).

Ainda no Leviatã, Hobbes define sensação como "o movimento provocado nos órgãos e partes inferiores do corpo do homem pela ação das coisas que vemos, ouvimos etc." (idem, p.46) da mesma forma, a imaginação também possui sua origem na sensação e nada mais é que "o resíduo do mesmo movimento que permanece depois da sensação [...] E dado que o andar, falar e os outros movimentos voluntários dependem sempre de um pensamento anterior de como, onde e o que, é evidente que a imaginação é a primeira origem interna de todos os movimentos voluntários" (idem, p.47). Em outras palavras, imaginação ${ }^{2}$ é uma "sensação em declínio" (idem, p.18). Pensar a imaginação como origem dos movimentos voluntários (paixões) é entender que a própria imaginação é um efeito provocado pela sensação causada pela ação de objetos externos, ou seja, a imaginação é resultado do processo de percepção passado e que permanece de forma residual. Quando Hobbes afirma que a imaginação é ao mesmo tempo um efeito de uma sensação e origem dos movimentos voluntários, isso significa que ela é sempre preenchida por conteúdos experienciais que, quando presentes, atuarão como dados com os quais se realiza o processo de cálculo que resultará em uma ação voluntária. Por isso, é possível dizer que as paixões não são reações diretas da ação de um corpo externo, é preciso antes que a sensação do corpo externo passe pela imaginação, e somente após esse passo é que será possível calcular essas experiências e deliberar em favor ou não de uma determinada ação. É dessa forma que Hobbes pode dizer que a imaginação é a origem interna dos movimentos voluntários sem que essa afirmação seja um contrassenso

2 "Imaginação e memória são uma e mesma coisa, que, por várias razões, têm nomes diferentes” (Hobbes, 2003, p.19, grifo nosso). 
em relação à outra que diz que tudo que está contido na imaginação é efeito da ação dos movimentos dos corpos externos. A imaginação recebe o conteúdo experiencial e, posteriormente, trabalha esse conteúdo em um cálculo de apetites e aversões (deliberação) de modo a produzir uma ação. Assim, mesmo sendo resultado do acúmulo de experiências recebidas por meio dos sentidos, a imaginação pode ser tomada como origem interna dos movimentos voluntários.

Contudo, a origem externa dos movimentos voluntários continua sendo a sensação provocada pelos objetos externos, o que, mais uma vez, explica a razão pela qual podemos dizer que a ação voluntária não é um resultado direto da ação dos movimentos externos, e sim um resultado indireto, pois ao receber a ação do movimento dos objetos externos a ação não se segue diretamente, ela antes disso passa por um processo de cálculo de apetites e aversões que projeta possíveis perdas e (ou) ganhos.

Se, por um lado, não parece ser possível afirmar que as paixões humanas são simples reações diretas produzidas pela ação dos objetos externos, parece ser possível por outro lado, entender que não há nada no campo da filosofia moral que seja original e essencialmente humano e que seja, ao mesmo tempo, medida universal e comum no estado de simples natureza. Os movimentos voluntários (as paixões), os desejos e aversões são pensados sempre em relação ao meio em que estão inseridos, e isso não significa que existam diferentes paixões tanto quanto diferentes forem os homens, pois as paixões "são as mesmas em todos os homens” (idem, p.13). O que é incerto e está em constante modificação são "os objetos das paixões, que são as coisas desejadas, temidas, esperadas etc" (idem). Isso ocorre porque no estado de simples natureza não há estabilidade ou constância no que se refere aos objetos que afetam os homens. Ainda que as paixões humanas sejam as mesmas em cada um dos indivíduos, os objetos externos que são responsáveis pela imaginação e por suscitar essas paixões humanas não serão sempre os mesmos.

Pensar as paixões como reações indiretas produzidas pela ação de objetos externos e pela imaginação não é incompatível com o fato de 
que o homem hobbesiano é capaz de deliberar ${ }^{3}$ e ter ações que podem ser chamadas de voluntárias. Considerando que a deliberação é o surgimento no espírito humano de:

apetites e aversões, esperanças e medos, relativamente a uma mesma coisa; [que] quando passam sucessivamente pelo pensamento as diversas consequências boas ou más de praticar ou abster-se de praticar a coisa proposta, de modo tal que às vezes se sente um apetite em relação a ela, e às vezes uma aversão, às vezes a esperança de ser capaz de praticar, e às vezes o desespero ou medo de a empreender, toda a soma de desejos, aversões, esperanças e medos, que se vão desenrolando até que a ação seja praticada, ou considerada impossível, leva o nome de DELIBERAÇÃO (idem, p.55, grifo nosso).

Nesse sentido, parece ser possível unir os conceitos de deliberação e de reação, pois se o primeiro diz respeito ao cálculo (soma) dos desejos e aversões que resultam na prática ou não de uma ação, o segundo também é um cálculo das sensações produzidas pela ação dos objetos e pela imaginação. Ou seja, deliberar ou reagir é levar em consideração a ação de objetos externos que afetam de forma direta ou indireta nossos órgãos dos sentidos, isto é, a ação do homem jamais é independente da ação dos objetos que lhe são externos. Direta ou indiretamente, eles condicionam a ação do homem, por isso é possível entender as paixões humanas como reações. Parece correto dizer que não são simples reações mecânicas à ação direta de um objeto externo (pois a imaginação e a experiência contribuem para o processo de formação das paixões), mas é uma reação na medida que a própria

3 Contudo, dizer que o homem delibera e pode ponderar acerca de suas ações não significa que ele possui uma liberdade no sentido de um sujeito autônomo que possa ser considerado no sentido iluminista do termo autonomia, istoé, por meio do esclarecimento racional que o torne capaz de dar leis de conduta a si próprio. Quando Hobbes diz que o homem delibera e pode ponderar sobre suas vontades, isso significa que o homem possui um locus de ação restrito apenas ao espaço onde não exista nenhum impedimento externo (seja natural ou artificial), pois "liberdade em sentido próprio significa ausência de oposição (entendendo por oposição os impedimentos externos do movimento)” (Hobbes, 2003, p.179). 
ideia de deliberação é tomada como cálculo dos desejos e aversões e eles são resultados da ação de objetos externos unidos ao cálculo da experiência acumulada na imaginação.

Por ser naturalmente impossível exercer um controle no sentido de estabilizar ou tornar constantes os objetos que afetam os sentidos humanos, também parece ser muito difícil naturalmente exercer qualquer controle sobre as paixões humanas, já que elas dependem dos objetos externos. Em consequência desse fato, também parece ser pouco provável que os homens possam estabelecer qualquer tipo de acordo que seja amparado em uma moralidade universal que seja produto da própria natureza. Pois se as paixões dependem direta ou indiretamente da ação do movimento dos objetos externos e esses objetos no estado de simples natureza não são constantes, isto é, variam de um homem para outro, então a consequência desses movimentos externos, que são as paixões humanas, é diretamente proporcional à variação desses objetos. ${ }^{4} \mathrm{O}$ que é constante é a natureza humana, ela não se modifica, ${ }^{5}$ o homem sempre busca naturalmente sua própria satisfação e isso ocorre porque, segundo Spragens, "Hobbes assume que toda a ordem natural incluído o homem 'que é a mais excelente obra da natureza' move-se fundamentalmente no mesmo caminho" (Spragens, 1973, p.176). ${ }^{6}$ É nesse sentido que é possível afirmar que

4 Quando se diz que não há um padrão de moralidade que seja universalmente válido no estado de simples natureza e que isso deriva de uma abordagem das paixões humanas (especialmente da consideração que se segue nesse trabalho), é preciso levar em consideração que não fazemos aqui uma diferenciação entre o que Hobbes entende por ética e o que ele entende por moral, pois ambas, ética e moral são o estudo das "consequências das paixões dos homens" (Hobbes, 2003, p.74). Spragens (1973, p.109) sustenta ainda que em Hobbes a ética é "expressão da vontade, ou para usar um termo mais contemporâneo, expressões de preferência". ...expressions of will, or the use the more contemporary term, expressions of preference.

5 Com relação à imutabilidade da natureza humana, Limongi (1999, p.13) afirma que o projeto de Hobbes não visa à "educação sentimental ou a transformação interna do agente moral, mas a alteração do contexto de inscrição das paixões”.

6 "Hobbes assumes that the entire natural order including man, 'that most excellent work of nature', moves in fundamentally the same way" (Spragens, 1973, p.176) 
Hobbes entende a constituição do homem (corpo humano) a partir de uma visão mecânica. ${ }^{7}$

Mais uma vez, é preciso entender que as paixões possuem um conteúdo valorativo, isto é, não há uma total ausência de valores no estado de natureza, afinal "todo homem é desejoso do que é bom para ele, e foge do que é mal” (Hobbes, 1998, p.31, grifo nosso) e a consideração privada do bem e do mal são julgamentos de valor. No entanto, a definição do que é bem e mal fica a cargo da decisão de cada indivíduo, e como no estado de natureza a busca do bem individual não traz necessariamente o bem coletivo, seguir o próprio julgamento é inversamente proporcional à possibilidade de existência de qualquer medida moral universal e comum no estado de simples natureza.

Novamente, é possível entender as paixões como reação indireta da ação dos objetos externos que afetam os sentidos e provocam as sensações, e que os resíduos ou o declínio dessas sensações são chamados de imaginação. Como vimos acima, todos movimentos antes de serem praticados são concebidos pela imaginação, pois o "andar, falar e os outros movimentos voluntários dependem sempre de um pensamento anterior de como, onde e o que”, por isso é legítimo falar que a imaginação é a "origem interna de todos os movimentos voluntários (paixões)” (Hobbes, 2003, p.47).

A imaginação, portanto, quando tomada em relação às paixões humanas possui a mesma função e ocupa o mesmo papel que o esforço chamado conatus. Contudo, o conatus não é a mesma coisa que a imaginação, a imaginação é a experiência na mente de movimentos causados por objetos externos, isto é, a sensação em declínio de um objeto, uma sensação obscurecida. Já o conatus é o início do movimento voluntário (das paixões), mas ele pode ser propriamente definido apenas como movimento (Hobbes, 1966, p.206). ${ }^{8}$ E esse movimento,

7 Nesse sentido, diz Frateschi (2003a, p.72): “A conexão entre a visão do homem e a concepção mecânica de natureza é, portanto, um aspecto fundamental da obra hobbesiana... [isso porque] o comportamento humano é determinado, principal e primeiramente, por uma tendência natural, e não por imperativos irredutivelmente morais"

8 "In like manner, endeavour [conatus] is to be conceived as motion". 
segundo Limongi (1999, p.32), possui o papel de atuar como "mediação entre a recepção do movimento dos corpos exteriores sobre o nosso corpo e a ação", de tal modo que o que é tomado por conatus se desenvolve em duas direções, como desejo ${ }^{9}$ ou aversão.

Será na trilha dessa formulação que o conceito de conatus surgirá para explicar o início dos movimentos internos, ou seja, no interior de uma teoria geral da propagação do movimento. Dentro de uma noção de movimento, como causa de todas as determinações dos corpos, é que se inscreve e se especifica o conceito de conatus. Ele é indispensável para entendermos as paixões humanas, sua geração, suas características e consequências, já que ocupa um lugar central na discussão acerca das paixões humanas.

O desenvolvimento e a definição em torno desse conceito começam a se precisar no interior da discussão entre Hobbes e Descartes acerca da noção de movimento e do conceito de inclinação. Descartes concebe o movimento como dependente da noção de inclinação, de modo que ela forneceria uma espécie de "estrutura do meio" que determinaria as condições espaciais do movimento. O que Descartes tomou como inclinação Hobbes entende como conatus, isto é, Descartes afirma que há condições externas ao movimento que determinam e prescrevem a direção do movimento. Hobbes, por sua vez, ao lançar mão do conceito de conatus, indica que o movimento não necessita dessa espécie de "estrutura externa" ou "estrutura prévia" que o direcione. Com o intuito de fundamentar esse novo enfoque acerca do movimento, ele define o conatus como uma determinação atual do próprio movimento. Essa concepção o conduz à tese de que os corpos possuem em si certos movimentos imperceptíveis, esses movimentos excluem a necessidade de conceber uma estrutura externa que o determine. ${ }^{10}$

9 Hobbes sempre une os conceitos de apetite e desejo como nomes que se referem à mesma coisa e podem ser utilizados indistintamente. Contudo, aqui utilizaremos sempre o primeiro nome, a saber, desejo, pois no Leviatã Hobbes (2003, p.47) diz que apetite é "frequentemente limitado a significar o desejo de alimento, nomeadamente fome e sede", já o desejo é um nome mais geral.

10 Acerca da distinção entre a abordagem hobbesiana do conatus e a abordagem cartesiana do conceito de inclinação. Cf. Limongi, 1999, p.29. 
Contudo, a noção de conatus inserida no interior da teoria das paixões não encontra sua origem no corpo mesmo como uma espécie de essência, pois como afirma Limongi (idem, p.29), "o conatus sempre dependerá da incidência de movimentos de outros corpos sobre ele". Mas se é assim, isto é, se o processo de conhecimento depende de uma afecção externa, como poderíamos explicar o fato de que Hobbes diz que o conatus é um princípio e um "impulso interno" do movimento? Essa afirmação de Hobbes parece apontar para uma incompatibilidade de princípios, isto é, como podemos conciliar a afirmação de que o processo de conhecimento depende da incidência de movimentos externos, e, ao mesmo tempo, aceitar que existe um princípio interno do movimento, que é o conatus. Seria essa então uma contradição interna própria do hobbesiano? Parece que não.

Quando Hobbes diz que o apetite e seu contrário, a aversão, são paixões de onde se originam as ações voluntárias, e que ambas podem ser definidas como conatus, ${ }^{11}$ ou seja, "pequenos inícios do movimento, no interior do corpo do homem, antes de se manifestarem no andar, na fala, na luta e outras ações visíveis" (Hobbes, 2003, p.47), ele parece nos sugerir outra via interpretativa.

No Leviatã, Hobbes (idem, p.11) aproxima o funcionamento do corpo humano com o funcionamento de uma máquina ao dizer que os órgãos do corpo humano possuem cada um uma função mecânica, a saber, o "coração é como uma mola, os nervos, cordas e as juntas, rodas, de tal forma que todos esses elementos unidos imprimem movimento (vida) ao corpo". Nesse momento, Hobbes parece explicar a função do conatus, ou seja, ele é essa "mola" que imprime movimento ao corpo. Ao aproximar um órgão componente da estrutura interna humana (o coração) a um artifício mecânico próprio das máquinas (a mola), Hobbes parece nos dizer que esse é o elemento que recebe (movimento passivo) o movimento causado pelos objetos externos e o transforma em ação (movimento ativo), ou seja, o conatus é uma

11 "Principia haec motus parva, intra humanus corpus sita, antequam incendendo, loquendo, percutiendo, caeterisque actionibus visibilibus appareant, vocantur conatus" (Opera Latina, in Hobbes, v.3, 1966c, p.40). 
espécie de mecanismo transformador que converte o movimento passivo em ativo.

Assim como uma mola que recebe uma força externa e, posteriormente, devolve essa força em forma de ação, o coração humano também processa esse redirecionamento no interior do corpo humano. Ele é quem padece (donde temos paixão) o movimento dos corpos externos, inverte sua direção, e reenvia esse movimento ao corpo em forma de ação, movendo assim os membros do corpo humano, braços, pernas, mãos etc. Portanto, parece ser possível dizer que o conatus é o início ou princípio interno do movimento voluntário, pois como vimos ele é um mecanismo de dupla função, de um lado ele recebe (padece) o movimento externo; de outro, ele, como um princípio interno do movimento, esforça-se por imprimir movimento ao corpo humano.

Assim, podemos unir duas afirmações: a filosofia de Hobbes privilegia o contexto de inserção das paixões humanas, de tal forma que depende dos movimentos externos; e o conatus é o princípio interno do movimento voluntário, como ele afirma nos Elementos de Lei.

Esse movimento, que consiste de prazer ou de dor, é também uma solicitação ou provocação seja para aproximar da coisa que deseja, ou para afastar da coisa que lhe desagrada. E esta solicitação é o esforço (endeavour) ou impulso interior (internal beginnig) do movimento animal, que é chamado apetite quando o objeto deleita, e é chamado aversão acerca do desprazer presente. (Hobbes, 1969, p.28) ${ }^{12}$

Postular a existência de um princípio interno do movimento significa dizer que, segundo o que se nos parece à percepção, o conatus é o início dos movimentos internos. Porém, isso é o que nos parece,

12 "This motion, in which consisteth pleasure or pain, is also a solicitation or provocation either to draw near to the thing that pleaseth, or to retire from the thing that displeaseth. And this solicitation is the endeavour or internal beginning of animal motion, which when the object delighteth, is called APPETITE; when it displeaseth, it is called AVERSION, in respect of the displeasure present;" 
pois como sabemos, nenhum corpo move-se a si mesmo, para que ele se mova é necessário, ação de um corpo externo, como afirma Hobbes (2003, p.17): "Nenhum homem duvida da verdade da seguinte afirmação: quando uma coisa está em repouso, permanecerá sempre em repouso, a não ser que algo a coloque em movimento". Assim, o conatus só pode ser tido como princípio interno do movimento pelo fato de que ele é um transformador do movimento que ele mesmo recebe dos objetos externos. Ao receber esse movimento externo, o conatus primeiramente não atua como esforço, mas sim como uma espécie de corpo que padece. Contudo, quando ele transforma o movimento, isto é, quando ele muda sua direção, ele passa a agir como um princípio ativo e não mais passivo, isto é, como esforço, do que decorre ser possível afirmar que o conatus é o princípio interno do movimento.

Portanto, ele é o mecanismo interno do homem que padece e age, que sofre e imprime movimento no corpo humano. Da mesma forma, o desejo e a aversão (as paixões primárias de onde derivam todas as outras) podem também ser chamados de princípio interno do movimento, de maneira que são conatus e possuem a mesma causa externa que as sensações de prazer e desprazer.

Quando se manifesta como desejo é sinal de que o esforço do movimento se desenvolve em direção ao objeto que o causou, quando se manifesta como aversão, significa que esse mesmo esforço se dá na direção contrária ao que o causou.

E como é possível saber que tal objeto será desejado ou não? Bem, o conatus por ser o movimento interno primordial, trabalha sempre no sentido de buscar a preservação da vida, como diz Hobbes (1966c, p.98), ele é "desejo de conservação de si" ${ }^{13}$ da mesma forma que a aversão, portanto, é a primeira "ameaça” a esse desejo, ou seja, é o distanciamento da morte. O conatus, portanto, pode também ser entendido como um movimento que busca uma futura apropriação daquilo que é útil para a conservação e o distanciamento de tudo

13 "sua cuique conservatio". 
que possa significar ameaça a sua preservação. É, nesse sentido, que Hobbes (2003, p.49, grifo nosso) anuncia que:

[...] quando a ação de um mesmo objeto se prolonga, a partir dos olhos, dos ouvidos e outros órgãos, até o coração, o efeito aí realmente produzido não passa de movimento ou esforço, que consiste em apetite ou aversão em relação ao objeto movente.

Pode-se pensar que, por se desenvolver em duas direções (como desejo ou como aversão), o conatus enquanto movimento primordial pode ser pensado como dois movimentos. Nesse sentido, poder-se-ia perguntar: é possível sustentar que existam dois princípios internos do movimento, isto é, dois conatus? A resposta parece ser negativa.

Ainda que possa se desenvolver em duas direções, o movimento que busca repudiar o mal, aproximar-se do que é bom e auxiliar o movimento vital é um só. É o mesmo conatus que atua como princípio interno dos movimentos voluntários, isto é, das paixões humanas. Nesse sentido, afirma Monzani (1995, p.79) que:

Não há nenhum dualismo original em Hobbes, como se poderia ser levado a pensar: existe uma única tendência, que nos inclina a certas coisas, e nos leva a repudiar outras. É o mesmo desejo que se especifica em aproximação ou distanciamento, conforme o caso. Desejo de preservação.

Esse movimento primordial que se manifesta inicialmente como desejo ou aversão pode ser em um segundo momento comparado ao amor e ao ódio. O desejo de um objeto transforma-se em amor quando se tem sua fruição, ou seja, o desejo transforma-se em amor quando o objeto desejado é alcançado. O mesmo se pode dizer com relação ao ódio, pois a aversão a um objeto transforma-se em ódio quando o objeto da aversão é colocado diante de nós. Nesse sentido que Hobbes passa da consideração acerca do desejo para a consideração acerca do amor quando diz que "o desejo e o amor são a mesma coisa, salvo que por desejo sempre queremos dizer a ausência do 
objeto, e por amor, mais comumente a presença desse objeto" (Hobbes, 2003, p.49). O mesmo pode se dizer com relação à aversão e o ódio, por aversão "queremos dizer a ausência, e por ódio, a presença do objeto" (idem). ${ }^{14}$

Quando Hobbes entende que o desejo e a aversão são os dois primeiros modos em que o conatus se manifesta, ele faz derivar dessa consideração inicial todas as demais paixões humanas, de tal forma que, do par fundamental desejo/aversão se seguem o par amor/ ódio, prazer/desprazer, esperança/medo, alegria/tristeza etc. Cada elemento que constitui esses pares representa exatamente o contrário do outro, ou seja, a direção da ação resultante do movimento que causa o desejo é contrária à direção da ação resultante do movimento que causa a aversão, e o mesmo pode se dizer em relação aos pares amor/ódio, esperança/medo.

Contudo, o que se pretende aqui não é investigar todas as paixões e todas as consequências que podem ser derivadas de cada uma delas, mais sim centrar em apenas duas dessas paixões, a saber, o medo e a esperança. E a razão de se escolher essas duas em especial se justifica na medida em que Hobbes expressa abertamente no Leviatã que elas são paixões que fazem o homem tender para a paz. Diz Hobbes (idem, p.111, grifo nosso):

As paixões que fazem os homens tenderem para a paz são o medo da morte, o desejo daquelas coisas que são necessárias para uma vida confortável e a esperança de as conseguir por meio do trabalho.

O desejo de alcançar as coisas necessárias para uma boa vida atua aqui como a primeira manifestação do movimento inicial (conatus), mas que tem sua manifestação um pouco mais especifica logo quando Hobbes aponta que esse desejo se mostra como uma esperança de se conseguir a paz. No Leviatã, ele define desejo como "Esforço que vai

14 As mesmas considerações acerca da passagem do par desejo/aversão para o par amor/ódio podem ser encontradas nos Elements of Law. Cf. Hobbes, 1969b, p. $28-9$. 
na direção de algo que o causa" (idem, p.47) dessa forma a definição desse conceito reúne e sintetiza todas as paixões que vão em direção àquilo que as causam. Nesse sentido, a esperança é também um desejo (apetite), assim como o amor, a coragem, a confiança, a ambição, a benevolência, a cobiça, a ânsia de vingança e a curiosidade, ${ }^{15}$ todas essas paixões são formas distintas de manifestação do desejo. Tratase a partir de agora de analisar a razão que faz que Hobbes escolha exatamente a esperança como paixão (derivada do desejo) que levam os homens à paz. E porque não qualquer outra paixão também derivada do desejo como o amor, a benevolência, a cobiça, a ambição, a curiosidade etc. Assim como a esperança é um desejo, o medo é uma aversão, que segundo Hobbes é o "esforço que vai na direção contrária de alguma coisa" (idem) de modo que se trata também de entender porque Hobbes elege o medo como paixão (derivada da aversão) dentre aquelas propícias a retirar o homem de sua condição de tensão natural. Por isso não será analisado mais de perto o "desejo de alcançar as coisas necessárias para uma boa vida” já que se entende que esse desejo está contemplado na consideração da esperança. O desejo de alcançar os meios para uma boa vida é a manifestação no homem do princípio da perpetuação do movimento, ou seja, do princípio do "benefício próprio" conforme diz Frateschi, todo homem deseja aquilo que é bom para si e se afasta daquilo que é mau. Esse é um princípio geral que deriva da aplicação no homem da teoria mecânica do movimento inercial, conforme foi mostrado no primeiro capítulo. Por isso, a esperança de alcançar os meios que levam o homem a uma boa vida, ou seja, a busca pelo bem individual, é o mesmo que o desejo individual pelo conjunto de todos os desejos e apetites unidos. Desejo e esperança portanto, têm a mesma função, se o desejo "vai em direção a algo" a esperança por sua vez é "a expectativa de alcançar algo", tanto uma quanto a outra ainda não têm a fruição do objeto no presente, porém têm a expectativa e o desejo de possuí-lo. A esperança e o desejo são unidos pela busca e pela expectativa de bem futuro. Contudo, dentre

15 Cf. Leviatã, cap.VI, Da origem interna dos movimentos voluntários vulgarmente chamados paixões; e Da linguagem que os exprime. 
todos esses desejos Hobbes elege a esperança como aquela que pode, ao lado da paixão do medo, contribuir para a paz. Trata-se então de entender porque a esperança e o medo desempenham essa função dentro do complexo passional hobbesiano.

\section{O medo entre a guerra e a paz}

O medo e a esperança são antes de tudo uma aversão e um desejo, como tais eles são movimentos presentes no indivíduo causados pela ação de movimentos de objetos externos. No entanto, essas paixões possuem uma característica peculiar em relação às demais, pois tanto uma quanto a outra dizem respeito a questões futuras, isto é, tanto o medo quanto a esperança são paixões que podem ser definidas como expectativas. Nos Elementos de Lei, Hobbes traz uma definição que aproxima essas duas paixões ao mostrar que elas são opiniões acerca do bem e do mal, isto é, antes de tudo expectativas de bem e de mal:

A esperança é expectativa de um bem por vir, assim como o medoé a expectativa de um mal. Mas quando aí existem causas, algumas das quais nos fazem expectar o bem e outras nos fazem expectar o mal, operando alternadamente em nossa mente, se as causas que fazem expectar o bem forem mais do que aquelas que nos fazem expectar o mal, a paixão como um todo é esperança. Caso se dê o contrário, o todo é medo. (Hobbes,1969, p.39-40, grifo nosso) ${ }^{16}$

A esperança e o medo atuam de tal modo a calcular as causas passadas que levam a uma expectativa futura e não necessariamente a um diagnóstico presente. No estado de simples natureza, o

16 "HOPE is expectation of good to come, as fear is the expectation of evil: but where there be causes, some that make us expect good, and some that make us expect evil, alternately working in our minds: if the causes that make us expect good, be greater than those that make us expect evil, the whole passion is hope; if contrarily, the whole is fear." 
medo leva o indivíduo a considerar uma ação futura em direção ao distanciamento do objeto causador da paixão, já a esperança leva o indivíduo a considerar uma ação futura que caminhe na direção da aproximação dos objetos causadores da paixão. Isso porque, o medoé também desprazer e a esperança é prazer, e a consideração do prazer ou desprazer está diretamente ligada à ajuda que eles oferecem ao prosseguimento do movimento vital. O Leviatã é claro quando diz que o "prazer parece constituir uma corroboração do movimento vital" (Hobbes, 2003, p.50) da mesma forma que o desprazer é a paixão que impede ou perturba o mesmo movimento.

O contexto em que o medo e a esperança se manifestam é o mesmo, contudo, os objetos das paixões humanas variam de homem para homem, pois o julgamento dos "objetos das paixões, que são as coisas desejadas, temidas, esperadas etc." (idem, p.13) está sempre em constante modificação. Assim, os homens, ainda que dentro de um mesmo contexto, calculam as causas de suas paixões e chegam a conclusões (ações) diferentes, ou seja, não só o cálculo quanto ao valor dos objetos como por consequência também as paixões que decorrem desse cálculo variam de homem para homem. Isso ocorre graças ao princípio da busca constante pelo autointeresse, ou busca pelo "benefício próprio" conforme utiliza Frateschi, pois cada homem calcula os meios e as ferramentas necessárias para seu próprio bem e seu próprio poder visando à preservação de sua vida.

Nesse sentido, têm-se dois planos:

(1) O primeiro leva a considerar a natureza humana pensada a partir do princípio da ciência de base mecânica em que o homem, por ser um corpo natural, vive sob a égide das leis que regem uma espécie de cosmologia que oferece as regras básicas de funcionamento do mundo. E dessa cosmologia pode-se derivar que a busca do homem pela preservação da vida é tão natural, constante e invariável quanto à lei do movimento inercial. Porém, essa busca natural de cada indivíduo pelo seu próprio bem não leva ao bem coletivo ao contrário do que ocorre com alguns animais (notadamente as abelhas e as formigas). A busca pelo bem individual no 
homem choca-se com a busca pelo bem coletivo, isso leva a guerra generalizada. ${ }^{17}$

(2) O segundo plano é do contexto em que o homem está inserido. Tal contexto não permite a possibilidade de se fazer contratos e mantê-los, não é possível (sob pena de se entregar ao inimigo) confiar nos atos e palavras de cada indivíduo no estado de simples natureza.

Diante desses dois planos, Hobbes procura construir a paz interferindo no segundo, ou seja, no plano das relações humanas, ${ }^{18}$ no plano da configuração social que no estado de simples natureza não oferece ao homem condições para o desenvolvimento do:

17 Quando se diz que a busca do bem coletivo leva a guerra generalizada, não se quer mostrar ou defender que todo o tempo em que o homem vive no estado de natureza é tempo de guerra. Pois como diz Hobbes (2003, p.109, grifo nosso): “...a guerra não consiste apenas na batalha ou no ato de lutar, mas naquele lapso de tempo durante o qual a vontade de travar batalha é suficientemente conhecida. [...] Porque tal como a natureza do mau tempo não consiste em dois ou três chuviscos, mas numa tendência para chover durante vários dias seguidos, também a natureza da guerra não consiste na luta real, mas na conhecida disposição para tal, durante todo o tempo em que não há garantia do contrário".

18 Sobre o tema da impossibilidade da transformação interna do homem, podemos citar duas abordagens distintas acerca da causa que anima Hobbes a enfatizar os aspectos externos da "formação" humana (e portanto, das paixões que lhe são próprias) em detrimento de sua transformação interna: Maria I. Limongi afirma que "as paixões enquanto movimentos internos da mente, só se deixam pensar por suas causas externas ou a partir do contexto em que se formam. Daí, a atenção de Hobbes não estar voltada - e nem poderia - para a educação ou transformação interna do agente moral, mas para a alteração do contexto de inscrição das paixões. [Isso porque] Hobbes pensa a conduta humana sempre a partir do exterior" (Limongi, 1999, p.13). Por outro lado, Yara Frateschi justifica essa mesma posição de Hobbes elegendo uma causa distinta, ou seja, a não possibilidade de transformação interna do agente moral não se assentaria no fato de Hobbes "sempre pensar a conduta humana a partir do exterior", mas sim no fato de que "não se pode alterar a natureza humana. [Pois] O princípio do benefício próprio, que orienta a conduta humana, pode levar à guerra ou à paz, dependendo das circunstâncias. Entretanto, independe de qualquer contexto que os homens busquem benefícios e evitem prejuízos, pois essa é uma tendência humana natural" (Frateschi, 2003a, p.70, grifos da autora). Por enquanto, para o que se pretende nesse trabalho, mais vale notar a convergência entre as duas autoras no que se refere à impossibilidade da transformação interna do agir humano, do que a divergência com relação às causas que levam Hobbes a adotar tal posição. 
trabalho, pois o seu fruto é incerto [...] não há cultivo da terra, nem navegação, nem uso das mercadorias [...] não há construções confortáveis, $[\ldots]$ não há conhecimento, $[\ldots]$ nem artes, nem letras; não há sociedade". (idem, p.109) ${ }^{19}$

Portanto, Hobbes precisa oferecer uma solução para um dilema que surge de duas considerações:

(1) A natureza humana é imutável, isto é, a natureza não pode ser desnaturada.

(2) O contexto em que o homem está inserido é causa da formação das paixões humanas, e esse contexto se caracteriza pela instabilidade, istoé, pela inconstância e pela desconfiança que por sua vez leva ao medo mútuo.

A instabilidade típica do estado de simples natureza não pode produzir outra coisa senão algumas das causas da guerra generaliza$\mathrm{da}$, isto é, o medo e a desconfiança. ${ }^{20}$ A desconfiança leva os homens a atacar uns aos outros tendo em vista conquistar (ainda que provisoriamente) aquilo que naturalmente não têm, que é a segurança (cf. idem, p.108). Portanto, da avaliação exclusiva da própria natureza só é possível extrair desconfiança, inconstância, instabilidade, insegurança, em uma palavra, o medo.

Nesse contexto, não há como esperar de seu semelhante outra coisa senão a mesma desconfiança que anuncia a não possibilidade de construir qualquer vínculo estável que não possa ser quebrado

19 A esse respeito diz Frateschi (2003a, p.70. grifo da autora): “A equação que resulta na guerra é composta de dois elementos: natureza humana e estado de natureza (onde há direito ilimitado de todos a todas as coisas). O elemento variável é o segundo, porque Hobbes não conta com a possibilidade de que os homens venham a sofrer qualquer processo de desnaturalização e tampouco aposta numa profunda e duradoura transformação do homem por meio da educação"

20 Desconfiança que é derivada da igualdade natural que traz o receio mútuo de que qualquer homem possa, de acordo com Hobbes (2003, p.107), "desapossar e privar, não apenas o fruto do seu trabalho, mas também da sua vida ou da sua liberdade" 
de forma justa por qualquer motivo de ordem individual. Hobbes é ciente disso quando cunha a frase lapidar que diz que "os vínculos das palavras são demasiado fracos para refrear a ambição, a avareza, a cólera e outras paixões dos homens" (idem, p.119).

Tal constatação coloca no horizonte dos homens no estado de simples natureza a possibilidade de sempre ser, de alguma forma, prejudicado direta ou indiretamente pelas ações de seus semelhantes. Por isso, uma das formas de se eliminar tal tensão e suas causas está diretamente ligada à construção de um mecanismo que saiba lidar com esse "vínculo fraco" que necessariamente leva ao medo e a desconfiança que são causas da instabilidade e da insegurança das relações entre os homens, ou seja, da guerra.

$\mathrm{O}$ ambiente de medo e desconfiança pode ser visto em várias passagens da obra de Hobbes, por exemplo quando ele define direito de natureza no Leviatã como a "liberdade que cada homem possui de usar seu próprio poder, da maneira que quiser, para a preservação de sua natureza" (idem, p.112, grifo nosso). Ora, de acordo com essa passagem percebe-se que o direito natural autoriza fazer uso daquilo que for necessário, segundo seu próprio julgamento, para alcançar seus desejos individuais. E esse direito vai além dos objetos necessários para a preservação da vida, diz Hobbes que se preciso for, o "homem tem direito até mesmo aos corpos uns dos outros" (idem, p.113, grifo nosso) de modo que cada homem pode, e na condição de simples natureza deve, utilizar-se dos outros homens como meio ${ }^{21}$

21 Vale ressaltar aqui que na filosofia de Hobbes o homem e a humanidade em geral jamais são pensados como "fim em si mesmos" como é possível e desejável na construção políticossocial proposta por Kant. Se no filósofo alemão a humanidade e cada indivíduo devem ser vistos como ponto de convergência de todos os esforços, em Hobbes o homem no estado de natureza tem assegurado pelo direito natural que, se preciso for, ele é autorizado a fazer uso dos corpos dos outros homens como meio para a sua própria preservação. Em um primeiro momento, o que nos parece estar por trás desse posicionamento diametralmente oposto entre Hobbes e Kant é a noção de autonomia individual que não está presente no autor inglês e é uma das principais características de Kant. Não avançaremos nessa discussão neste trabalho, mas pretendemos tratar dessa distinção em outro momento. 
para a obtenção de seus desejos e, principalmente, para a preservação de sua vida.

Note-se que ao autorizar tal conduta, não há como impedir que a tensão e o medo sejam decorrentes desse direito. Se eu e meu semelhante temos o direito natural de agir conforme nosso próprio julgamento individual, não havendo qualquer restrição natural que possa nos impedir de tal conduta, é também natural que o medo e a desconfiança se sigam desse direito.

O que garante o acesso do homem a todos os meios necessários para se preservar é o direito de natureza. A lei de natureza, por sua vez, é uma regra geral que aconselha ao homem não abrir mão de seu direito natural de fazer uso do que for necessário para sua preservação, ou seja, a lei natural (no estado de simples natureza) é uma regra geral que mantém a lógica que estabelece como consequência necessária à presença do medo e da desconfiança recíproca entre os homens. A esse respeito conclui Hobbes (idem, p.113) que:

Portanto, enquanto perdurar este direito natural de cada homem a todas as coisas, não poderá haver para nenhum homem (por mais forte e sábio que seja) a segurança de viver todo o tempo que geralmente a natureza permite aos homens viver.

A insegurança com relação à própria vida é o principal resultado da consideração acerca do direito e da lei natural, como a preservação da vida é o maior dos bens que um homem possui então aquilo que ameaça a vida humana é o maior mal. Eé natural que o homem se afaste de tudo aquilo que é mal, ${ }^{22}$ e a paixão que faz o homem se afastar do mal é a aversão, e "A aversão ligada à crença [opinião] de dano proveniente do objeto, chama-se MEDO” (idem, p.51, grifos do autor). Portanto, a insegurança gerada pela consideração da lei e do direito natural só pode causar uma paixão no homem, qual seja, o medo.

22 “todo homem é desejoso do que é bom para ele, e foge do que é mal” (Hobbes, 1998, p.31). 
Por ser impossível eliminar uma paixão natural, é preciso saber ordenar o medo para que ele não seja causa da guerra, e sim contribua para a paz, para isso é necessária uma ferramenta externa à natureza, isto é, é preciso que os homens estabeleçam o contrato com o fim de construir a paz conforme prescreve a segunda lei natural:

Que um homem concorde, quando outros também o façam, e na medida em que tal considere necessário para a paz e para a defesa de si mesmo, em resignar o seu direito a todas as coisas, contentando-se, em relação aos outros homens, com a mesma liberdade que aos outros homens permite em relação a si mesmo (idem, p.113).

Somente esse elemento externo às paixões poderá estabelecer as ferramentas que podem redirecionar a desconfiança e o medo recíprocos entre os homens com o intuito que eles trabalhem em função da paz e não da guerra.

No entanto, a confiança necessária capaz de obrigar os homens a manterem a palavra dada e a cumprirem os pactos estabelecidos vem a reboque de um "temor respeitoso" imposto pelo Estado soberano, ou seja, é por meio do medo de um poder comum capaz de impor externamente o cumprimento das leis que se pode alcançar a estabilidade e a constância necessária para o convívio pacífico. Porém sem eliminar a desconfiança, mas sim a reorganizando em função da obediência ao soberano civil que é a única forma possível de se alcançar a paz, pois se fosse possível alcançar a paz "sem um poder comum que mativesse a todos em respeito, igualmente conseguiríamos imaginar a humanidade inteira capaz de fazer o mesmo" (Hobbes, 2003, p.145). E, nesse caso, "não haveria, nem seria necessário, nenhum governo civil ou república, pois haveria paz sem sujeição" (idem).

O que temos aqui então é que só se pode construir o mínimo de harmonia e estabilidade necessária para uma vida segura porque essas características são garantidas pelo medo, é ele quem regula e constrói artificialmente os parâmetros necessários ao estabelecimento da paz. O soberano que exerce seu poder como "temor respeitoso" é que dará sustentação e estabilidade necessárias para que a 
desconfiança $a^{23}$ dentro do Estado leve os homens à paz e não à guerra. Contudo, é imperativo perceber que o Estado civil nasce principalmente como um poder exercido pelo temor. Ainda que seja temor e não terror, percebe-se que o Estado precisa exercer seu poder de modo a utilizar o medo, paixão cujo par opositivo é a esperança, desse modo o complexo criado por essas duas paixões pode dar ao Estado a possibilidade de construção da paz pelo controle dos objetos das paixões. Assim, o Estado, por meio da força e do temor imposto aos súditos, trabalha com as esperanças e os medos individuais com o intuito de afastar a guerra e construir a paz.

O Estado civil é a única instância capaz de construir a paz e produzir o mínimo de garantias necessárias para que a esperança possa atuar ao lado do medo e da desconfiança própria do estado de simples natureza. O Estado civil soberano é o único "poder comum capaz de mantê-los [os homens] todos em temor respeitoso" (idem, p.109, grifo nosso). Indiretamente, portanto, é o medo que prepara o terreno para o desenvolvimento da confiança (que é esperança constante) e atuando juntos, esperanças e medos, controlados pelo Estado por meio da obediência, são as bases para a edificação da paz política.

O quadro geral comum de descrição da filosofia de Hobbes é tido como a busca de abandonar o estado de simples natureza que é de guerra e tensão e, através do contrato de transferência de direitos, estabelecer um estado soberano que afaste a guerra e construa a paz. Se quisermos traduzir essa descrição geral para um vocabulário das paixões humanas diríamos que: Hobbes procura dirimir o conflito natural das paixões humanas construindo um artifício mecânico que visa conter a tensão natural por meio da reorganização dos objetos das paixões, ou seja, no estado de simples natureza as relações

23 Essa desconfiança própria da natureza humana porém não é eliminada, é preciso notar que ela é trabalhada lado a lado com a confiança que, é reoganizada artificialmente pelas mãos do Estado, e que só pode se desenvolver pela atuação do Estado soberano. Ao construir o corpo político artificial, Hobbes não propõe a transformação da natureza humana, e isso significa que a desconfiança e a tensão passional humana permanece sufocada pelo temor respeitoso exercido pelo Estado soberano. 
humanas são pautadas pela vigência suprema da desconfiança e do medo que, necessariamente, levam a guerra. Com a construção do Estado soberano, o medo (desconfiança) e a esperança (confiança) são regulados para que a guerra não seja seu produto necessário desse jogo passional, mas sim a paz. E isso ocorre por meio do exercício do poder soberano pautado na obediência civil.

Quando Hobbes diz que o medo (ao lado da esperança)éa paixão que faz os homens tenderem para a paz, é pelo fato de o medo ser a paixão que parece mais adequadamente descrever à desconfiança natural, isto é, por ser uma paixão resultante de um contexto de instabilidade. Por isso Hobbes elege o medo, e não outra paixão qualquer como a raiva, o ódio, a tristeza, o desespero, a cólera etc. como uma daquelas paixões que podem levar o homem a tender para a paz. Se por um lado a instabilidade leva ao medo e, consequentemente, a possibilidade eminente de morte que é o pior do males que um homem pode sofrer, por outro lado, o cálculo das causas e consequências do medo pode levar o homem a considerar formas futuras de eliminar essa tensão. Por isso Hobbes diz que, para sair do estado de simples natureza, o homem deve se valer em "parte das paixões [notadamente o medo e a esperança] e em parte de sua razão" (idem, p.111). O cálculo racional acerca das causas e consequências do medo pode levar os homens para a paz porque os levam a consideração e a expectativa de um futuro em que possa gozar da segurança (que é um bem, pois garante a preservação da vida) que não há no estado de simples natureza. E a paixão por excelência que sintetiza a expectativa de um bem futuro é a esperança.

Finalmente, se o medo é uma paixão que pode ser caracterizada pela desconfiança é pouco provável que ela possa ser tomada como uma paixão capaz de oferecer um padrão comum natural, ou uma medida natural universal que tenha força suficiente para estabelecer uma regra moral antes mesmo da construção do Estado civil soberano. $\mathrm{O}$ resultado da instabilidade natural tanto pode ser o medo como pode ser também a busca por poder e mais poder como anuncia Hobbes no Leviatã (cf.idem, p. 85 ss) e que Strauss (cf.Strauss, 1963, p.11 ss) interpreta como traço de vaidade tipicamente humana. 
A tensão e a instabilidade fazem que os homens não tenham nenhuma garantia de que suas vidas sejam preservadas, desse modo o acúmulo infinito de poder individual é a única ferramenta natural que eles possuem para ser utilizada contra essa natureza que os entrega à própria sorte. Desse modo, a busca por poder não pode, como procura sustentar Strauss, ser uma mostra da vaidade humana, mas sim um resultado da tendência natural humana de buscar os meios necessários para a preservação da vida no estado de natureza, isto é, não pode ser tomada como um traço moral natural capaz de amparar o edifício teórico hobbesiano. O que também pode ser aplicado à paixão que analisamos aqui, qual seja, o medo.

A busca incessante por poder, bem como o medo, também se caracteriza pela inconstância, pela insegurança e pela desconfiança. Por exemplo, a busca individual por glória é um sinal da necessidade que o homem possui de obter poder, dado que o homem busca glória porque ela traz "reputação" (Hobbes, 2003, p.108) de tal modo que "reputação de poder é poder" e "reputação de prudência [...] é poder" (idem, p.76). A busca por glória nãoé, portanto, um sinal de vaidade, mas uma forma de adquirir mais poder. E essas características podem ser melhor entendidas e compreendidas à luz de uma consideração de ordem mecânica ou seja, considerando a influência da filosofia natural hobbesiana em sua filosofia política, conforme esperamos ter mostrado nos capítulos 1 e 2 .

\section{A esperança entre a guerra e a paz}

No plano das paixões humanas, o papel do Estado é fazer com que as esperanças e os medos sejam trabalhados e reorganizados em função da obediência civil que é a única forma de construir a paz. Contudo, isso não significa que o medo é eliminado do estado civil ou que a esperança não exista quando ainda é vigente o estado de simples natureza. Como já salientado aqui, as paixões humanas são sempre as mesmas, o que muda é o contexto de inserção dessas paixões. O que o Estado propicia é a mudança do contexto externo 
de modo que aquelas paixões presentes no estado de simples natureza que eram causa da guerra, agora dentro do Estado soberano possam trabalhar em favor da paz e da segurança. Afinal, a finalidade do Estado é dar a estabilidade necessária para que os homens possam garantir sua preservação e levar uma vida mais satisfeita, ou seja, o Estado procura satisfazer o desejo de:

sair daquela mísera condição de guerra, que é consequência necessária (conforme se mostrou) das paixões naturais dos homens, quando não há um poder visível capaz de os manter em respeito (Hobbes, 2003, p.143. grifo nosso).

A condição de guerra natural é caracterizada fundamentalmente pela instabilidade, pela desconfiança e pelo medo, nesse sentido, o poder visível que Hobbes menciona tem como principal objetivo no plano das paixões humanas, sufocar, reprimir e reordenar essas paixões no sentido de que o convívio entre os homens possa ser construído não com instabilidade, mas com paz e com segurança. Para isso, ele deve utilizar-se da desconfiança e da confiança, dos medos e esperanças, e fazê-las instrumentos para a construção da paz e não mais causas da guerra generalizada.

Quando se analisa a definição de confiança dada no Leviatã, é possível perceber que ela é "construída" levando em consideração um importante elemento para a filosofia de Hobbes, que é o de constância. A confiança é uma paixão derivada de uma esperança constante "a esperança constante chama-se confiança” (idem, p.51, grifo nosso). Já nos Elementos de Lei, a confiança é tida como "uma paixão que procede da crença naqueles de quem esperamos algum bem" (Hobbes, 1969, p.40, grifo nosso). ${ }^{24}$ Do mesmo modo, a esperança é tida como "a expectativa de um bem por vir" 25 (idem, grifo nosso).

24 "TRUST is a passion proceeding from belief of him from whom we expect or hope for good" (Hobbes, 1969b, p.40).

25 "HOPE is expectation of good to come" (Hobbes, 1969b, p.39). 
Sem o Estado soberano e sem o poder que ele traz consigo, não pode haver uma confiança comum capaz de estabelecer os padrões e as garantias necessárias para o convívio social e para a preservação da vida, pois sem ele "cada um confiará, e poderá legitimamente confiar, apenas na sua própria força e capacidade” (Hobbes, 2003, p.144). E o Estado só é capaz de estabelecer esses padrões e garantias por meio do medo ou temor respeitoso.

É notório que as definições de esperança e de confiança dadas tanto nos Elementos de Lei quanto no Leviatã são próximas na medida em que ambas são movidas pela "expectativa de bem". Porém a confiança é, de certa forma, derivada da esperança na medida em que procede da crença (opinião) de um indivíduo que tem a expectativa constante de bem, ou seja, que tenha esperança constante. E dentro desse quadro o conceito de constância também é de grande relevância para a abordagem das paixões humanas na medida em que o movimento externo (ou seja, tudo o que afeta o homem e que está fora dele, e que causa uma consequência interna que, por sua vez, gera um sentimento que provocará a ação do indivíduo) pode ser mudado. Pois os objetos externos que afetam os órgãos dos sentidos e partes inferiores do corpo do homem (a vista, o ouvido, o gosto, o tato) são diversos e essa diversificação acarreta a mudança no diagnóstico dado pela sensibilidade, o que, por sua vez, interfere na continuidade das paixões que são reações indiretas da ação dos movimentos externos. Portanto, é também pelo fato de que a esperança é constante que essa paixão pode ser chamada confiança, assim, esperança só pode ser considerada confiança na medida de sua constância.

O que a relação entre essas duas paixões, a esperança e a confiança, pode nos ajudar a entender o modo como se considera a moral e a ética dentro do estado de simples natureza, isto é, porque é importante entender a relação entre a esperança e a confiança e o fato de que a moral no estado de simples natureza não é capaz de oferecer uma medida comum universal capaz de unir os homens de modo pacífico sem a interferência do corpo político construído artificialmente?

Bem, como já vimos, a confiança resulta da constância da expectativa de bem, isto é, da esperança, e, se por um lado, a desconfiança 
natural é causa da discórdia e da desunião, a confiança, por sua vez, pode ser mensageira da união entre os homens. No estado de natureza, os homens não confiam uns nos outros porque tal comportamento significa se entregar como vítima a seu semelhante, já que no estado de guerra à fraude é a melhor ferramenta como diz o preceito ou regra geral da razão: "Que todo homem deve se esforçar pela paz, na medida em que tenha esperança de a conseguir, e caso não a consiga pode procurar e usar todas as ajudas e vantagens da guerra" (idem, p.113, grifo nosso).

Sem confiança (que é uma paixão), não há expectativa de que se possa construir a paz que é o melhor modo de se preservar a vida, que, por sua vez, é o maior dos bens que o homem pode possuir. A esperança é uma paixão natural que se constitui da expectativa de bem futuro, porém a invariabilidade dessa paixão, ou seja, sua constância não é possível de ser garantida no estado de simples natureza, pois os objetos das paixões, isto é, as coisas desejadas pelos homens são diversas e variáveis tanto quanto a instrução de cada um (cf.idem, p.13). Portanto, há esperança no estado de simples natureza, o que não há são as garantias de que essa paixão seja constante e duradoura, assim como nada no estado de natureza possui a garantia de ser constante e duradouro. Se o medo no estado de natureza é uma paixão "fortemente" presente entre os homens, a esperança por seu turno, como diz Hobbes no Leviatã, é uma paixão que não pode ser nada mais que "um apetite, ligado à crença de conseguir" (idem, p.50). Nesse sentido, não há possibilidade de estabelecer a paz tomando a esperança e o medo natural como ponto de partida. Apenas com a interferência do poder soberano exercido pelo Estado é que essas paixões podem atuar em função da paz civil.

Porém, no estado de natureza, só é possível conseguir aquilo que seu próprio poder é capaz de manter já que "todo homem tem direito a todas as coisas” (idem, p.113) e, nesse sentido, a esperança de manter amanhã aquilo que se conquistou hoje é fundada apenas numa opinião (crença), que é por direito natural, partilhada por todos os homens. 
No entanto, essa opinião ou crença em conseguir o que é bom para si mesmo não assegura o alcance do bem desejado, dado que todos a possuem. E quando todos partilham do mesmo direito o resultado que se tem é sua anulação recíproca, ou seja, a adição dos direitos individuais é uma equação de soma zero. $\mathrm{O}$ fato de todos terem naturalmente a mesma opinião em conseguir alcançar os bens desejados tem como resultado prático uma situação de descrença. E isso leva a instabilidade que, por sua vez, traz a desconfiança. Contudo, no interior do corpo político, as leis civis promulgadas pelo poder soberano têm por função dar estabilidade e medida comum da justiça e da injustiça, pois diferentemente das leis naturais, ${ }^{26} \mathrm{a}$ lei civil "não é um conselho, mas uma ordem" (idem, p.226). A lei civil estabelece a regra e a medida que deve ser usada por todos os súditos "como critério de distinção entre o bem e o mal, isto é, do que é contrário à guerra" (idem).

Ao estabelecer a regra e a medida comum que devem ser respeitadas e obedecidas por todos de maneira comum e universal, o Estado por meio da lei civil, constrói o campo em que a paz pode se desenvolver já que ele dá a medida, dá a estabilidade, isto é, dá a constância necessária para que a esperança e o medo possam ser paixões que trabalhem para a manutenção da paz.

Quando propõe o Estado como única forma capaz de oferecer a confiança e a estabilidade necessárias para se construir a paz, Hobbes tem a compreensão de que esse Estado possui suas "carências" já que, em última análise, seu poder está amparado no "temor respeitoso" e no exercício de uma soberania, que, por definição, tem de ser absoluta. Contudo, tais "carências" não impedem que o Estado soberano enquanto tal possa, sem prejuízo da justiça, usar de todos os meios para garantir a paz e a preservação da vida. Entretanto, se esse Estado aumentar demasiadamente a taxa de impostos, for violento, criar desavenças entre os súditos por distribuir mal as riquezas da república, não garantir a preservação da vida etc. os indivíduos que

26 De acordo com o Leviatã, as leis naturais são "preceitos ou regras gerais" (Hobbes, 2003, p.112). 
formam esse Estado irão resistir ${ }^{27}$ à força do soberano. E essa resistência se fará graças a algo que pode provisoriamente ser chamado de "inabilidade de governo", pois a constituição do Estado tal como Hobbes o concebe, afirma que "as ações dos homens derivam de suas opiniões, e é no bom governo das opiniões que consiste o bom governo das ações" (idem, p.152). Se um cidadão, em sua avaliação individual, isto é, em seu cálculo privado, concluir que a obediência irrestrita ao Estado não lhe traz nenhum benefício individual, então é natural que ele resista ao Estado ainda que não esteja amparado por nenhuma lei civil. Como a natureza humana sempre permanecerá a mesma, o princípio da busca pela satisfação dos desejos individuais também permanecerá sempre como um traço tipicamente humano, e a obediência ao soberano só fará sentido se ela for mais proveitosa aos homens do que o estado de simples natureza em que todos os homens têm direitos a tudo.

Hobbes é ciente dos possíveis inconvenientes presentes em um governo soberano constituído sobre essas bases, e deixa isso claro quando caminha no sentido de afirmar que ainda que possa haver motivo de dissenso no Estado civil, esse dissenso é infinitamente menor

27 Contudo, é importante salientar que em Hobbes não há um direito à rebelião como podemos ver por exemplo em Locke que diz que: “...todo aquele que, investido de autoridade, exceda o poder que lhe é conferido por lei e faça uso da força que tem sob seu comando para impor ao súdito o que a lei não permite [...] pode ser combatido como qualquer outro homem que pela força invade o direito alheio" (Locke, 2001, p.202). Em Hobbes, o homem só pode resistir ao poder do Estado quando ele não realizar as funções para as quais foi construído, no entanto, essa resistência será sempre injusta, pois quando os homens transferem todos os seus direitos, eles passam a ser autores de todas as ações do soberano, por isso, resistir ao governo significa voltar-se contra si mesmo. As ações do soberano são de autoria dos súditos, o representante é apenas o ator dessas ações, e os homens devem obedecer ao poder soberano, porque a obediência está de acordo com a natureza e com a preservação. A revolta nunca é legítima nem justa, mas a resistência pode ocorrer quando a obediência não mais garantir a paz, nesse caso ela (obediência) não será de acordo com a natureza, e os homens poderão, em nome da própria preservação, desobedecer, isto é, resistir, porém injustamente, dado que a justiça é a palavra do soberano, portanto, desobedecer sempre será injusto. Cf. Hobbes, 2003, p.115, e cap. XXI. 
que as intempéries causadas pela guerra proveniente da instabilidade e inconstância das paixões humanas típicas do estado de natureza.

o estado do homem nunca pode deixar de ter uma ou outra incomodidade, e que a maior que é possível cair sobre um povo em geral, em qualquer forma de governo, é de pouca monta quando comparada com as misérias e horríveis calamidades que acompanham a guerra civil, ou aquela condição dissoluta de homens sem senhor, sem sujeição às leis e a um poder coercitivo capaz de atar as suas mãos, impedindo a rapina e a vingança (idem, p.157).

Não há como construir um corpo artificial sem que ele traga em seus "genes" algumas características do corpo humano que o produziu, ou seja, mesmo no Estado soberano é possível que exista alguma "incomodidade", pois ele é resultado do esforço humano de construir as "lentes prospectivas [...] que permitem [aos homens] ver de longe as misérias que os ameaçam" (idem, p.158). Por não possuir naturalmente tais lentes, o homem facilmente cede ao julgo das paixões que o induz à busca e à satisfação de seus desejos mais próximos, pois naturalmente e sem o esforço e a ajuda externa do artifício estatal os homens não abrirão mão da satisfação imediata de seus desejos em nome de um bem futuro construído "em longo prazo". Isso porque a satisfação das paixões humanas auxilia na manutenção do movimento vital, assim como o bom uso da reta razão.

Contudo, a busca pelos objetos que satisfazem as paixões humanas ocorre de maneira mais direta e mais simples, isto é, mediante a ação dos movimentos dos objetos externos provocados nos órgãos dos sentidos, o homem primeiro sofre a ação do movimento do corpo externo, só após esse sofrimento ele reage em direção à obtenção ou distanciamento do objeto externo.

Já a razão, por sua vez, também pode auxiliar a manutenção do movimento vital, porém só é possível desenvolver um cálculo racional "com esforço, primeiro por uma adequada imposição de nomes, e em segundo lugar obtendo-se um método bom e ordenado para proceder dos elementos, que são nomes, a asserções feitas por conexão de um 
deles com um outro" (idem, p.43, grifo nosso). Desse modo, podese perceber que ainda que a razão e as paixões estejam presentes na natureza de cada homem, quando comparada uma a outra, as paixões se sobressaem "pois em geral as paixões humanas são mais fortes do que a razão” (idem, p.160, grifo nosso). Por isso, no estado de simples natureza as paixões seduzem o homem de forma mais incisiva já que ela é motivada por um elemento externo que não exige um esforço primário em direção à realização ou não de uma determinada ação. Já a razão necessita de um esforço primário e diligente do próprio indivíduo, o que dificulta o exercício racional quando comparado às paixões humanas.

Portanto, o temor respeitoso que o Estado impõe sobre seus súditos é a forma com que o soberano tem de, no plano político, construir um artifício que reorganize o plano natural do conflito passional humano para que ele atue não em função da guerra, mas sim a favor da viabilização e da manutenção da paz. Esse plano artificial é a garantia política de que a desconfiança natural, causada pela busca da satisfação imediata das paixões e pela busca da preservação da vida, possa ser trabalhada ao lado da confiança, isto é, o Estado procura artificialmente e por meio do exercício do temor respeitoso controlar os objetos das paixões produzindo a estabilidade necessária para garantir a paz e a segurança inexistente no estado de simples natureza. Entretanto, a própria esperança não é capaz de produzir e manter a paz, apenas com a construção do Estado é que se torna possível trabalhar as esperanças e os medos a serviço da paz. Apenas a regularidade e a estabilidade da lei civil (viabilizada pelo Estado soberano) é que pode fazer que a paixão da esperança, sempre atrelada ao medo, possa atuar no convívio social de modo a forjar a paz. Somente quando a confiança viabilizada pela lei vigorar entre os homens é que o medo da morte violenta poderá ser afastado e a garantia da preservação da vida assegurada.

A esperança e o medo propiciam um cálculo futuro, ou seja, se reorganizados e trabalhados em função da obediência ao soberano civil, essas paixões podem sim dar ao homem a expectativa de que, ao realizar o contrato de transferência de direitos, seu desejo funda- 
mental (que é a preservação da vida) possa ser garantido. E isso está em consonância com o que Hobbes afirma no final do capítulo XIII do Leviatã quando diz que a esperança e o medo podem auxiliar o processo de construção da paz. Porém, é fundamental perceber que isso não ocorre naturalmente, mas apenas com a atuação do Estado no sentido de redirecionar e reorganizar essas paixões em função da paz pelo único meio possível que é a sujeição às leis civis.

Se, por um lado, o medo pode calcular a situação presente e passada e concluir pela desconfiança natural que deve ser superada, por outro lado, a esperança é capaz de calcular em direção ao futuro com vistas à construção de um convívio social que não seja amparado na guerra e na desconfiança, e sim no bem individual. É tarefa do Estado fazer que os medos e as esperanças individuais confluam para a paz coletiva. Esse exercício realizado pelo poder soberano é que garante que o medo e esperança estejam sempre presentes e, nesse sentido, uma paixão não pode ser pensada sem a outra.

Mas é possível ainda uma última objeção: como foi mostrado acima, no estado de natureza o medo traz a desconfiança, e ela é característica da guerra e da tensão natural, sendo assim, como o medo pode ser pensado lado a lado com a esperança de tal modo que esperanças e medos possam ao mesmo tempo trabalhar em função da paz e da segurança civil?

Ora, é fato que o medo traz desconfiança e essa paixão é uma das causas da guerra, porém não é o "medo simplesmente" um dos causadores da tensão natural entre os homens, e sim o medo mútuo, o medo recíproco próprio da convivência no simples estado de natureza. A reciprocidade na consideração de seu próprio poder e do poder do outro é que leva os homens à desconfiança e ao conflito generalizado. No entanto, o medo exercido pelo poder soberano não gera desconfiança, pois ele não é um medo recíproco. Os súditos devem temer seu soberano, mas a contrapartida não é necessária já que todo o poder do Estado está concentrado nas mãos da soberania que por definição tem de ser absoluta, de modo que não há medo recíproco entre súditos e soberano. O que deriva do medo que o soberano exerce sobre os súditos não é o medo do soberano em relação aos súditos, mas sim a 
obediência dos súditos em relação ao soberano poder. A chave para o bom funcionamento do corpo político hobbesiano é a obediência absoluta que deve se seguir do exercício da soberania absoluta.

A obediência que deriva do medo dos súditos em relação ao soberano deve ser uma característica constante no interior do Estado civil, e essa constância é que pode trazer a estabilidade e a confiança na crença de que o soberano será capaz de oferecer a segurança e a garantia necessárias para que a esperança possa estar presente com mais vigor dentro do Estado civil. É nesse sentido que é possível sustentar que o medo é que ampara e prepara o terreno para o desenvolvimento da esperança, ou seja, é como medo exercido pelo soberano, um medo que elimina a tensão natural por meio da obediência. Ao eliminar a tensão, ele traz a estabilidade que, por sua vez, propicia a expectativa de um bem futuro, isto é, traz a esperança e o exercício constante dessa paixão traz a confiança. 



\section{Considerações finaIS}

Em Hobbes, a guerra e o estado de tensão generalizada são resultado do conflito natural das paixões humanas, pois não há como compatibilizar a tendência natural de todo homem querer "poder e mais poder" e desejar acima de tudo o "seu próprio bem", e ao mesmo tempo haver um convívio social pacífico e harmonioso no estado de simples natureza. Podemos chegar a tal conclusão pela investigação da filosofia moral que trata das consequências das paixões da mente. O desejo contínuo pelos bens individuais leva os homens necessariamente à guerra, ou seja, a própria natureza humana é responsável pela situação de desacordo, inconstância, desconfiança e medo em que está imersa. Uma variável que traz mais problema para essa consideração acerca da condição natural humana é o fato de que Hobbes parece entender que essa natureza não se modifica, isto é, o desejo de poder e a busca pelo próprio bem são traços naturais e permanentes do homem e com ele seguirá até a morte. Esse quadro fica mais evidente quando o aproximamos dos postulados hobbesianos acerca da filosofia natural de matriz mecanicista, que produz uma cosmologia que procura entender o mundo como um conjunto de corpos em movimento. Isso foi o que procuramos desenvolver nos dois primeiros capítulos deste trabalho.

Entretanto, esse estado natural em que a insegurança, a instabilidade, a desconfiança e o medo da morte violenta são as paixões que 
vigoram de maneira mais intensa, não oferece as bases necessárias para que os homens possam ter a garantia da preservação de suas vidas. Nesse sentido, surge a necessidade de construir um artifício que possa trazer a esperança de que a preservação da vida seja garantida. Esse artifício é o Estado civil soberano, ele nasce com a função de controlar os objetos das paixões humanas, isto é, surge para reorganizar e redirecionar o medo e a esperança de modo que atuem em função do Estado civil. Por isso, é possível dizer que em Hobbes a filosofia moral antecede a filosofia civil, pois ela trabalha com as consequências das paixões naturais. No entanto, dessa constatação não é possível afirmar que há em Hobbes uma moral universalista que sirva de padrão e medida da justiça. A filosofia moral é apenas a parte da filosofia que trata das paixões da mente e mostra-nos que essas paixões não são capazes de oferecer qualquer padrão de justiça. Esse padrão ou medida só será estabelecido artificialmente pelas mãos do Estado soberano como condição de possibilidade de estabelecer a paz e a segurança. O que no plano político significa dizer que o Estado é o único meio possível de afastar a guerra generalizada de todos contra todos e, posteriormente, construir a paz.

Contudo, o Estado civil soberano não é capaz de modificar as paixões naturais, de tal modo que a paz será construída através da reorganização e reordenação dessa natureza belicosa que, ao fim e ao cabo, permanecerá a mesma. Temos então o seguinte quadro:

(1) A natureza é causa do conflito e da guerra, e nessas condições não há possibilidade de um convívio social pacífico.

(2) O Estado surge como mecanismo para afastar a guerra e construir a paz, porém, não modifica a natureza humana.

Se a natureza humana não é propícia a fundar um convívio social que seja pacífico, e sim o contrário, ou seja, as paixões humanas invariavelmente entram em conflito umas com as outras e provocam a tensão e a guerra típica do estado de simples natureza, então como é possível ao Estado soberano lograr êxito em sua função de reorganizar as paixões humanas com o intuito de afastar a guerra e construir a paz, sem que seja possível modificar a natureza humana? 
A descrição pouco otimista de Hobbes com relação à natureza humana deixa como única alternativa para que se possa afastar a guerra e todas as consequências que dela derivam, a criação de um corpo político que seja capaz de fazer surgir a paz desse estado de tensão tipicamente natural. A competição, a desconfiança e a glória que são constitutivas da natureza humana impedem qualquer possibilidade de manutenção de qualquer acordo comum no estado de simples natureza. Portanto, em um primeiro momento, o Estado surge contra essa natureza instável que não oferece qualquer garantia de acordo e estabilidade possível, ou seja, é como um mecanismo que procurará estabelecer as condições que garantem a possibilidade de cumprir os pactos estabelecidos sem que isso signifique a entrega da própria vida. É como um corpo artificial que terá como principal função organizar o jogo passional natural (que é a causa principal do estado de guerra) em função da paz e da segurança recíproca.

Porém, se de um lado o Estado surge contra a natureza humana na medida em que uma de suas principais funções é reorganizar e dar limites à manifestação das paixões, por outro lado, a viabilização desse limite é a condição sine qua non para preservação da vida na medida em que a manifestação natural das paixões conduz os homens à guerra. Portanto, o Estado surge como limitador, organizador do conflito passional humano e essa limitação e organização artificial é a única forma de fazer que os homens possam sair do estado de guerra e construir a paz. Se, por um lado, à paz é o melhor meio de se preservar a vida, por outro lado para que isso ocorra é preciso, de certa forma, limitar e restringir a vida em sua manifestação passional.

Ora, o papel desempenhado pelo Estado é justamente o de "introduzir aquela restrição [sem a qual os homens não poderiam] viver em repúblicas" (Hobbes, 2003, p.143, grifo nosso), ou seja, o Estado é para os homens "a precaução com a sua própria conservação e com uma vida mais satisfeita" (idem). Contudo, como essa "restrição" e "precaução" é exercida pelo Estado soberano no sentido de afastar a guerra e produzir a paz tão necessária para a preservação da vida?

Bem, o Estado civil soberano surge como fiador da paz, no entanto é claro que as condições naturais do homem não permitem que essa 
paz seja construída sem "sujeição às leis e a um poder coercitivo" (idem, p.157, grifo nosso), e esse poder deve ser coercitivo, pois essa é a única forma capaz de manter os homens em respeito e os "forçar, por medo do castigo, à observância da lei e ao cumprimento dos pactos" (idem, p.143). Para construir a paz, é necessário que o Estado soberano mantenha os homens em "temor respeitoso [sem o qual] eles se encontram naquela condição a que se chama guerra” (idem, p.109).

A partir dessa consideração, temos que a coerção, restrição, sujeição e temor são algumas das principais características salientadas por Hobbes como norteadoras de uma direção em que o Estado possa obter sucesso em seu objetivo que é afastar a guerra e a tensão característica do estado de simples natureza e, ao mesmo tempo dar a segurança e a estabilidade necessárias para se construir e garantir a paz duradoura. No entanto, aqui cabe a seguinte questão: se Hobbes identifica as causas da guerra no conflito natural das paixões humanas e na natural disputa por poder que é necessária para se garantir a vida no estado de simples natureza, porque ele não constrói um Estado que atue modificando diretamente as causas da guerra (que é o conflito das paixões e a disputa por poder)? Por que ele propõe um Estado que não modifica mas coage, restringe, sujeita e impõe o medo a seus súditos?

A resposta a essas questões parece se dar no seguinte caminho: a consideração hobbesiana acerca da natureza humana não deixa espaço para possíveis transformações, ou seja, a natureza humana é imutável pois, "os sentidos, a memória, o entendimento, a razão e a opinião não podem por nós ser mudados à vontade” (idem, p.314), ou seja, as paixões humanas não mudam, assim como não muda a constituição natural do homem, pois suas faculdades são sempre as mesmas. ${ }^{1} \mathrm{O}$ que é passível de mudança é a causa das paixões e a capacidade de uso das faculdades, isto é, o cálculo (raciocínio) que

1 "Não parece que Hobbes tivesse a ilusão de que seria possível promover uma mudança profunda nos homens (a natureza não se altera). Sua intenção, aparentemente, não era transformar os homens, mas torná-los mais afeitos à obediência civil" (Frateschi, 2003b, p.107). 
cada homem faz de sua força, poder, glória, medo etc., pois elas são "sempre necessariamente como no-los sugerem as coisas que vemos, ouvimos e consideramos. Não são portanto efeitos da nossa vontade, é a nossa vontade que é efeito deles" (idem, p.314). Contudo, ainda que o cálculo e a causa das paixões e da opinião possam variar de indivíduo para indivíduo, essa variação não é significativa a ponto de não se poder afirmar que os homens são iguais por natureza (cf. idem, p.106). Se a natureza humana não muda, não mudam também a tensão e o conflito das paixões humanas, se elas não mudam não muda também o estado de guerra próprio do conflito passional natural.

Nesse sentido, seria vão que o Estado tivesse como objetivo primeiro modificar as paixões humanas; seria uma tarefa inglória e o objetivo jamais seria alcançado. O máximo que ele pode atingir é atuar no sentido de coagir, restringir, sujeitar e impor o "temor respeitoso" e o medo através do exercício do poder soberano, isto é, trata-se de reorganizar e reordenar as paixões humanas, não as transformando, mas as redirecionando em função da paz.

Contudo, quando o Estado faz uso dessas ferramentas para afastar a guerra e construir a paz, mesmo no interior do Estado civil já constituído, a tensão típica da natureza humana permanecerá, e Hobbes percebe isso quando diz que no Estado civil "a condição do súdito é muito miserável, pois se encontra sujeita à lascívia e a outras paixões irregulares daquele ou daqueles que detêm nas suas mãos poder tão ilimitado" (idem, p.157). Isto é, a tensão passional natural parece não ser eliminada mesmo no interior do Estado civil. O máximo que o Estado faz é "dotar os homens de lentes prospectivas (a saber, ciência moral e civil) que permitem ver de longe as misérias que os ameaçam", e que, segundo Hobbes, "sem [o Estado civil soberano] não podem ser evitadas" (idem, p.158).

Nesse sentido, parece ser possível sustentar que o Estado civil soberano pode não ser suficiente para garantir a paz e evitar a guerra utilizando-se apenas da repressão física, da limitação e da coação, pois a causa da guerra são as paixões humanas e, mesmo no Estado civil, elas permanecem as mesmas, ainda que limitadas, coagidas e restringidas pelo poder do Estado soberano. Ainda que o Estado 
tenha o direito de fazer uso da repressão física, ela não é suficiente para construir a paz duradoura, por isso, parece ser preciso fazer uso de algo como uma "repressão ideológica" que trabalhe no sentido de atuar além das questões meramente físicas e corporais. Além disso, a guerra não é o estado de conflito constante e ininterrupto nem o ato de lutar, ela é sim "aquele lapso de tempo durante o qual à vontade de travar batalha é suficientemente conhecida" (idem, p.109), e essa vontade permanece mesmo no âmbito do Estado civil soberano, pois o "perpétuo desejo de poder e mais poder" (idem, p.85) ou o "desejo do seu próprio bem" (Hobbes, 1969, p.73) é um impulso natural que permanece ainda no Estado civil soberano. O Estado soberano modifica "os objetos das paixões dos homens, pois esses objetos variam de indivíduo para indivíduo” (Hobbes, 2003, p.13), mas modificar os objetos das paixões, isto é, influenciar o contexto em que o homem está inserido, não significa necessariamente solucionar o conflito natural das paixões que causam a guerra, já que a tendência da natureza humana está amparada em uma lógica de busca pelo próprio bem e de competição por poder e glória. E isso é melhor entendido quando pensamos essa tendência pelo viés da filosofia natural que preconiza que todo corpo tende a perpetuar seu movimento, e como vida é movimento, perpetuar o movimento é perpetuar a vida. A vida é o maior dos bens, então a busca pela vida é a busca pelo próprio bem, ou como propõe Yara Frateschi, a busca pela vida é a busca pelo "benefício próprio".

A atuação do Estado soberano parece se dar não apenas no sentido de uma repressão física e corporal (ainda que ela também seja legítima e necessária), mas sim influenciar na formação das opiniões (consciência) dos súditos de tal modo que o cálculo racional individual resulte na vontade de obediência ao soberano poder, que, de acordo com Hobbes, é a única forma de manter o Estado civil.

Temos então dois planos:

(1) O Estado de natureza em que o homem não está sujeito a nenhum poder comum e que sua vida é "solitária, miserável, sórdida, brutal e curta” (idem, p.109), pois se caracteriza 
pela desconfiança, pelo medo, isto é, pela guerra de todos contra todos.

(2) O Estado civil em que o homem está sujeito a um poder soberano que é responsável por afastar a guerra tipicamente natural e construir a paz. Porém, o Estado constrói essa paz como uma "reorganização ou reordenação artificial" da natureza humana (que é imutável) e caracterizada pela tensão e pela guerra.

A concepção de natureza humana elaborada por Hobbes não permite que ele possa supor uma transformação do comportamento natural humano, os traços naturais permanecerão idênticos mesmo dentro de um corpo político já constituído. Diante disso algumas questões se colocam: Como fazer com que os homens deixem de agir naturalmente e aceitem as restrições, coações e limitações impostas pelo Estado para garantir a paz? Como compatibilizar em um mesmo plano o medo da morte violenta e o desejo de poder com a busca pelo próprio bem e a esperança de alcançar a paz colocada na viabilização do Estado que só pode ser construído por meio de limitações e restrições à natureza humana?

Parece claro que o Estado civil possui poder suficiente para afastar a guerra por meio da coação, restrição e sujeição dos súditos exercido pelo "temor respeitoso" que ele impõe. No entanto, seria insuficiente para promover a paz duradoura, pois ele (Estado civil) não modifica a natureza nem as paixões humanas que são a causa da guerra.

O papel desempenhado pelo Estado civil é de exercício do poder soberano, e esse poder é inócuo e impotente no que se refere à modificação da natureza humana, e, a partir daí, parece ser possível sustentar que Hobbes se volta para a mudança do contexto de inscrição das paixões interferindo nas relações entre os homens de modo que a disputa por esses objetos não seja motivo de conflito.

Para concluir, vale notar que se a ciência mecanicista de Hobbes nos esclarece e auxilia a compreender de forma mais ampla os dois grandes resultados de sua obra que são: de um lado a tensão generalizada causada pelo conflito das paixões humanas chamado guerra 
de todos contra todos. De outro lado, à construção de um Estado soberano que por meio da coerção e da reorganização dos objetos que causam as paixões humanas seja capaz de afastar a guerra e construir a paz. Essa mesma ciência mecanicista que permite entender a realidade pode (e talvez deva) ser auxiliada (e não contraposta) pelo uso da retórica no sentido de convencer os súditos de que o Estado soberano é a melhor forma de construir relações estáveis distantes da insegurança e do medo da morte violenta. Isso não significa que a filosofia e a ciência mecanicista não sejam capazes de demonstrar a necessidade da construção do Estado, mas sim que os súditos não são capazes de entender as longas cadeias causais que são necessárias para se demonstrar a necessidade de construir o Estado e obedecer a seu soberano poder.

No entanto, essa já é outra questão a ser trabalhada em uma nova fase de nossos estudos acerca da filosofia de Thomas Hobbes. 


\section{REFERÊNCIAS BIBLIOGRÁFICAS}

\section{Obras de Hobbes}

HOBBES, T., Troisièmes objections. In: Descartes Ouvres et Lettres, Paris, Gallimard, 1952.

The English Works of Thomas Hobbes. EdW. Molesworth, London, XI vols, 1966a.

. Leviathan sive de Matéria, Forma, et Potestate Civitatis Ecclesiasticae et Civilis. Opera Latina, London, Ed. W. Molesworth, Vol. III, 1966b.

. De Homini. In: Opera Latina, London, Ed. W. Molesworth, vol VI, 1966c.

. De Corpore. In: The English works of Thomas Hobbes, London, W. Molesworth, Vol. I, 1966d.

A short tract on first principles. Apêndice à edição do The Elements of Law, London, Frank Cass \& Co, 1969a.

The Elements of Law. Edited with a Preface and Critical Notes by Ferdinand Tönnies, London, Frank Cass \& Co, 1969b.

Do Cidadão. São Paulo, Martins Fontes, 1998.

On the citizen. Edited and translated by Richard Tuck and Michael Silverthorne, Cambridge University Press, 2000.

Leviatã ou matéria forma e poder de um Estado eclesiástico e civil.

Tradução João Paulo Monteiro e Maria Nizza da Silva, Martins Fontes, São Paulo, 2003.

. Elementos de Lei Natural e Política. Trad. e notas de Fernando Dias Andrade. Gentilmente cedido pelo tradutor. 


\section{Bibliografia secundária}

BARNOW, J. "Le Vocabulaire du Conatus". In : Zarka, Y. C, Hobbes et son Vocabulaire, Paris, Vrin, 1992.

BOBBIO, N. Thomas Hobbes. trad, Carlos Nelson Coutinho, Rio de Janeiro, Ed Campus, 1991.

BOONIM-VAIL, D. Thomas Hobbes and the science of moral virtue. New York, Cambridge Universit Press, 1994.

BOWLE, J. Hobbes and his critics. London, Jonathan Cape, 1951.

BRANDT, F. Thomas Hobbe's mechanical conception of nature. London, Levin \& Munsgaard, 1928.

FRATESCHI, Y. A Física da política: Hobbes contra Aristóteles. Tese de Doutoramento, USP, 2003a.

"A retórica na filosofia política de Thomas Hobbes". Revista Filosofia Política (UFRGS). Rio de Janeiro, Jorge Zahar, série 3, volume 6, p.94-108, 2003b.

GAUTHIER, D. P. The Logic of Leviathan: The Moral and Political Theory of Thomas Hobbes. Oxford, Clarendon Press, 1969.

GOLDSMITH, M. M. Hobbes's science of politics. New York, Columbia University Press, 1966.

HERBERT, G. B. Thomas Hobbes: The unity of scientific \& moral wisdom. Vancouver, University of British Columbia Press, 1989.

JOHNSTON, D. The Retoric of Leviatã. Princeton, University Press, 1986. KANTOROWICZ, E. H. Os dois corpos do rei, São Paulo, Cia das Letras, 1998.

LIMONGI, M. I. O homem excêntrico, paixões e virtudes em Thomas Hobbes. Tese de Doutoramento, USP, 1999.

LOCKE, J. Dois tratados sobre o governo civil. São Paulo, Martins Fontes, 2001.

"Hobbes e a virtude". Revista Filosofia Política (UFRGS), Rio de Janeiro, Jorge Zahar ed, série 3, volume 6, p.75-93, 2003.

MACPHERSON, C. B. A teoria política do individualismo possessivo. Rio de Janeiro, Paz e Terra, 1979.

MONZANI, R. Desejo e prazer na Idade Moderna. Campinas, Ed Unicamp, 1995.

NERNEY, G. "Homo notans: marks, signs and imagination in Hobbes's Conception of Human Nature" in: Hobbes Studies, vol IV, 1991.

POLIN, R. Politique et philosophie chez Thomas Hobbes. Paris, Puf, 1953. 
RIBEIRO DE MOURA, C. A, "Hobbes, Locke e a medida do direito" In: Racionalidade e Crise: Estudos de História da Filosofia Moderna e Contemporânea, Discurso Editorial/Editora UFPR, 2002.

RIBEIRO, R. J. A marca do Leviatã. São Paulo, Ática, 1978.

Ao leitor Sem medo. São Paulo, Brasiliense, 1984.

SKINNER, Q. Razão e Retórica na Filosofia de Thomas Hobbes. Ed. Unesp, São Paulo, 1999.

SPRAGENS, T. A. The politics of motion: the world of Thomas Hobbes. Kentucky, University Press, 1973.

STRAUSS, L. The political philosophy of Thomas Hobbes: It's basis and genesis. Chicago, The University Press, 1963.

Natural right and history, Chicago, University Press, 1953.

TAYLOR, A. E. "The ethical doctrine of Hobbes". In: BROWN, K. C, Hobbes Studies. Cambridge, Mass, Harvard University Press, 1965, pp.35-55.

TUCK, R. Hobbes. São Paulo, Ed Loyola, 2001.

Hobbes's moral philosophy". In: The Cambridge Companion to Hobbes. Cambridge, University Press, 1996; p.175-207.

WARRENDER, H. The political philosophy of Hobbes: his history of obligation. Oxford, Clarendon Press, 2000.

ZARKA, Y.-C. La decision métaphysique de Hobbes, Paris, Vrin, 1987. Hobbes et la pensée politique moderne, Paris, PUF, 1995. Hobbes et son vocabulaire, Paris, Vrin, 1992. 


\author{
SOBRE O LIVRO \\ Formato: $14 \times 21 \mathrm{~cm}$ \\ Mancha: 23,7 x 42,5 paicas \\ Tipologia: Horley Old Style 10,5/14 \\ 1 a edição: 2009 \\ EQUIPE DE REALIZAÇÃO \\ Coordenação Geral \\ Marcos Keith Takahashi
}




\section{CULTURA}

$\frac{\text { ACADÊMICA }}{\varepsilon d i t a n}$ 